\title{
Reviews and syntheses: Ocean iron fertilization experiments - past, present, and future looking to a future Korean Iron Fertilization Experiment in the Southern Ocean (KIFES) project
}

\author{
Joo-Eun Yoon ${ }^{1}$, Kyu-Cheul Yoo ${ }^{2}$, Alison M. Macdonald ${ }^{3}$, Ho-Il Yoon ${ }^{2}$, Ki-Tae Park ${ }^{2}$, Eun Jin Yang ${ }^{2}$, \\ Hyun-Cheol Kim², Jae Il Lee ${ }^{2}$, Min Kyung Lee ${ }^{2}$, Jinyoung Jung ${ }^{2}$, Jisoo Park ${ }^{2}$, Jiyoung Lee ${ }^{1}$, Soyeon Kim', \\ Seong-Su Kim ${ }^{1}$, Kitae Kim ${ }^{2}$, and Il-Nam Kim ${ }^{1}$ \\ ${ }^{1}$ Department of Marine Science, Incheon National University, Incheon 22012, Republic of Korea \\ ${ }^{2}$ Korea Polar Research Institute, Incheon 21990, Republic of Korea \\ ${ }^{3}$ Woods Hole Oceanographic Institution, MS 21, 266 Woods Hold Rd., Woods Hole, MA 02543, USA
}

Correspondence: Il-Nam Kim (ilnamkim@inu.ac.kr)

Received: 2 November 2016 - Discussion started: 15 November 2016

Revised: 16 August 2018 - Accepted: 18 August 2018 - Published: 5 October 2018

\begin{abstract}
Since the start of the industrial revolution, human activities have caused a rapid increase in atmospheric carbon dioxide $\left(\mathrm{CO}_{2}\right)$ concentrations, which have, in turn, had an impact on climate leading to global warming and ocean acidification. Various approaches have been proposed to reduce atmospheric $\mathrm{CO}_{2}$. The Martin (or iron) hypothesis suggests that ocean iron fertilization (OIF) could be an effective method for stimulating oceanic carbon sequestration through the biological pump in iron-limited, high-nutrient, low-chlorophyll (HNLC) regions. To test the Martin hypothesis, 13 artificial OIF (aOIF) experiments have been performed since 1990 in HNLC regions. These aOIF field experiments have demonstrated that primary production (PP) can be significantly enhanced by the artificial addition of iron. However, except in the Southern Ocean (SO) European Iron Fertilization Experiment (EIFEX), no significant change in the effectiveness of aOIF (i.e., the amount of iron-induced carbon export flux below the winter mixed layer depth, MLD) has been detected. These results, including possible side effects, have been debated amongst those who support and oppose aOIF experimentation, and many questions concerning the effectiveness of scientific aOIF, environmental side effects, and international aOIF law frameworks remain. In the context of increasing global and political concerns associated with climate change, it is valuable to examine the validity and usefulness of the aOIF experiments. Furthermore, it is logical to carry out such experiments because they allow one to study how plankton-based ecosystems work by
\end{abstract}

providing insight into mechanisms operating in real time and under in situ conditions. To maximize the effectiveness of aOIF experiments under international aOIF regulations in the future, we therefore suggest a design that incorporates several components. (1) Experiments conducted in the center of an eddy structure when grazing pressure is low and silicate levels are high (e.g., in the SO south of the polar front during early summer). (2) Shipboard observations extending over a minimum of $\sim 40$ days, with multiple iron injections (at least two or three iron infusions of $\sim 2000 \mathrm{~kg}$ with an interval of $\sim 10-15$ days to fertilize a patch of $300 \mathrm{~km}^{2}$ and obtain $\mathrm{a} \sim 2 \mathrm{nM}$ concentration). (3) Tracing of the iron-fertilized patch using both physical (e.g., a drifting buoy) and biogeochemical (e.g., sulfur hexafluoride, photosynthetic quantum efficiency, and partial pressure of $\mathrm{CO}_{2}$ ) tracers. (4) Employment of neutrally buoyant sediment traps (NBST) and application of the water-column-derived thorium-234 $\left({ }^{234} \mathrm{Th}\right)$ method at two depths (i.e., just below the in situ MLD and at the winter MLD), with autonomous profilers equipped with an underwater video profiler (UVP) and a transmissometer. (5) Monitoring of side effects on marine/ocean ecosystems, including production of climate-relevant gases (e.g., nitrous oxide, $\mathrm{N}_{2} \mathrm{O}$; dimethyl sulfide, DMS; and halogenated volatile organic compounds, HVOCs), decline in oxygen inventory, and development of toxic algae blooms, with optical-sensorequipped autonomous moored profilers and/or autonomous benthic vehicles. Lastly, we introduce the scientific aOIF ex- 


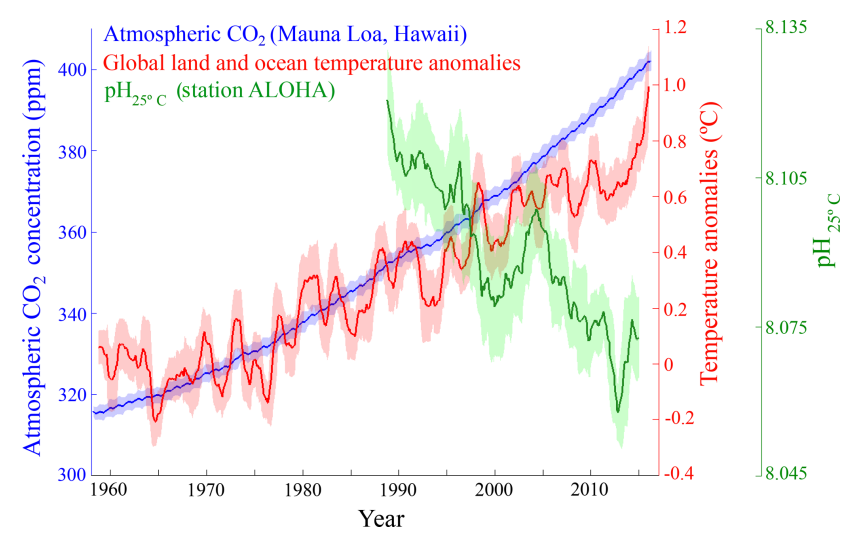

Figure 1. Diagram showing the monthly atmospheric $\mathrm{CO}_{2}$ concentrations (ppm) (blue) measured at the Mauna Loa Observatory, Hawaii (http://www.esrl.noaa.gov/gmd/ccgg/trends/data.html, last access: 6 September 2018); global monthly land-surface air and sea surface temperature anomalies $\left({ }^{\circ} \mathrm{C}\right)$ (red) (http://data.giss. nasa.gov/gistemp/, last access: 6 September 2018); and pH (green) measured at station ALOHA in the central North Pacific (http:// hahana.soest.hawaii.edu/hot/products/HOT_surface_CO2.txt). The data values represent moving average values for 12 months and shading indicates the standard deviation for 12 months.

perimental design guidelines for a future Korean Iron Fertilization Experiment in the Southern Ocean (KIFES).

\section{Introduction}

Since the start of the industrial revolution, human activities have caused a rapid increase in atmospheric carbon dioxide $\left(\mathrm{CO}_{2}\right.$, a major greenhouse gas) from $\sim 280 \mathrm{ppm}$ (pre-industrial revolution) to $\sim 400 \mathrm{ppm}$ (present day) (http: //www.esrl.noaa.gov/, last access: 6 September 2018), which has, in turn, led to global warming and ocean acidification, indicating that there is an urgent need to reduce global greenhouse gas emissions (IPCC, 2013) (Fig. 1). As the Anthropocene climate system has rapidly become more unpredictable, the scientific consensus is that the negative outcomes are a globally urgent issue that should be resolved in a timely manner for the sake of all life on Earth (IPCC, 1990, 1992, 1995, 2001, 2007, 2013). The various ideas and approaches that have been proposed to relieve and resolve the problem of global warming (Matthews, 1996; Lenton and Vaughan, 2009; Vaughan and Lenton, 2011; IPCC, 2014; Leung et al., 2014; Ming et al., 2014) largely fall into two categories: (1) reduction of atmospheric $\mathrm{CO}_{2}$ by the enhancement of biological $\mathrm{CO}_{2}$ uptake (including ocean fertilization) and/or the direct capture or storage of atmospheric $\mathrm{CO}_{2}$ through chemically engineered processes, and (2) control of solar radiation by artificial aerosol injection into the atmosphere to augment cloud formation and cloud brightening to elevate albedo (Fig. 2). One of the most attractive methods

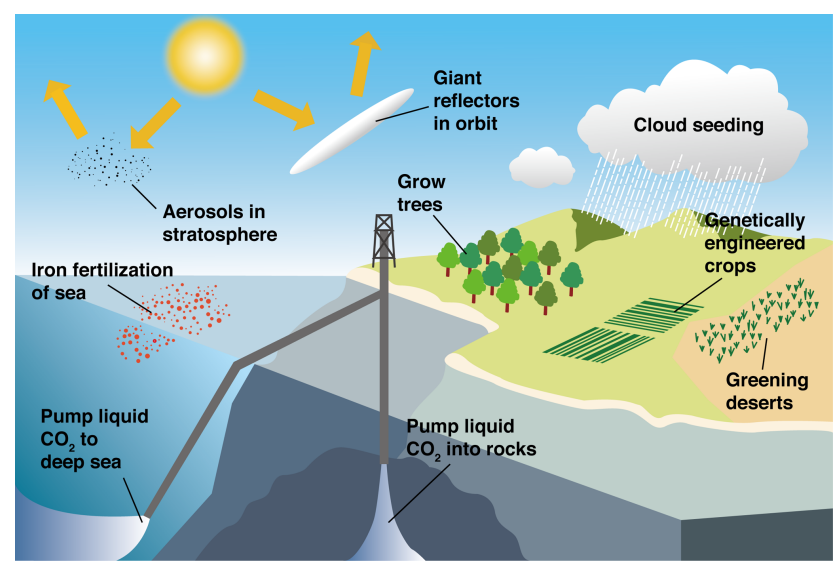

Figure 2. Schematic representation of several proposed climateengineering methods (modified from Matthews, 1996).

among the proposed approaches is ocean fertilization (https: //web.whoi.edu/ocb-fert/, last access: 6 September 2018), which targets the drawdown of atmospheric $\mathrm{CO}_{2}$ by nutrient addition (e.g., iron, nitrogen, or phosphorus compounds) to stimulate phytoplankton growth and, subsequently, carbon export to the deep ocean or sediments via the ocean biological pump (ACE CRC, 2015).

The ocean biological pump is frequently depicted as a single combined process, whereby organic matter produced by phytoplankton during photosynthesis in surface waters is quickly transported to intermediate and/or deep waters (Fig. 3a) (Volk and Hoffert, 1985; De La Rocha, 2007). Although the effectiveness of the biological pump is primarily controlled by the supply of macronutrients (i.e., nitrate, phosphate, and silicate) from the deep ocean into the mixed layer (ML), leading to new production (Sarmiento and Gruber, 2006), iron acts as an essential micronutrient to stimulate the uptake of macronutrients for phytoplankton growth (Fig. 3b) (Martin and Fitzwater, 1988; Martin, 1990; Morel and Price, 2003). In the subarctic North Pacific (NP), equatorial Pacific (EP), and Southern Ocean (SO), which are well known as high-nutrient and low-chlorophyll (HNLC) regions (Fig. 4a and b), phytoplankton cannot completely utilize the available macronutrients (particularly nitrate) for photosynthesis due to a lack of iron. As a consequence, primary production (PP) in these HNLC regions is relatively low, despite the high availability of macronutrients (in particular nitrate and phosphate) (Fig. 4a and b).

Analyses of trapped air bubbles in Arctic-Antarctic ice cores have revealed that atmospheric $\mathrm{CO}_{2}(\sim 180 \mathrm{ppm})$ during the Last Glacial Maximum (LGM; 20000 years ago) was much lower than during preindustrial times $(\sim 280 \mathrm{ppm})$ (Neftel et al., 1982; Barnola et al., 1987; Petit et al., 1999). Over the last 25 years, several hypotheses have been proposed to explain the lowered atmospheric $\mathrm{CO}_{2}$ level during the LGM (Broecker, 1982; McElroy, 1983; Falkowski, 1997; Broecker and Henderson, 1998; Sigman and Boyle, 2000). 
(a)

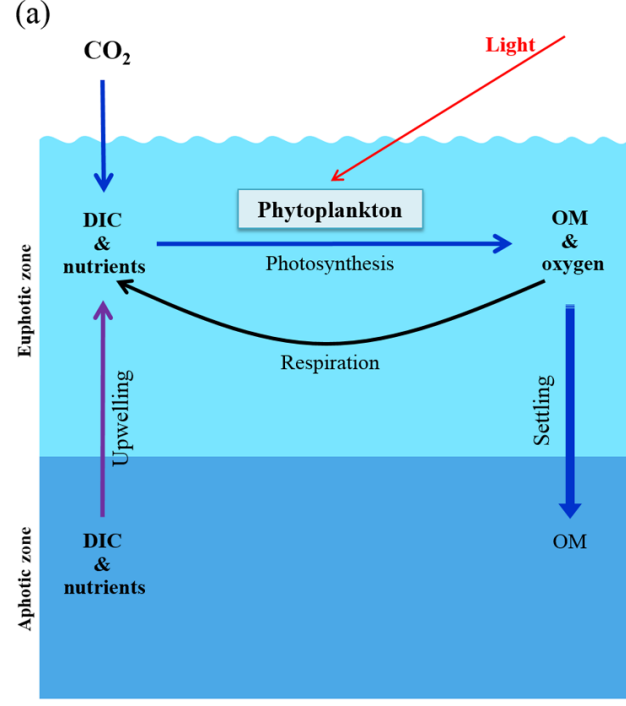

(b)

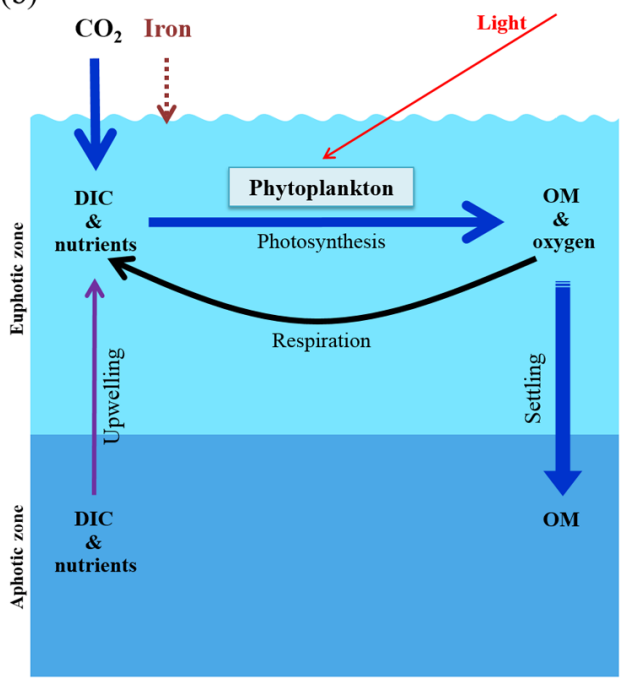

(c)

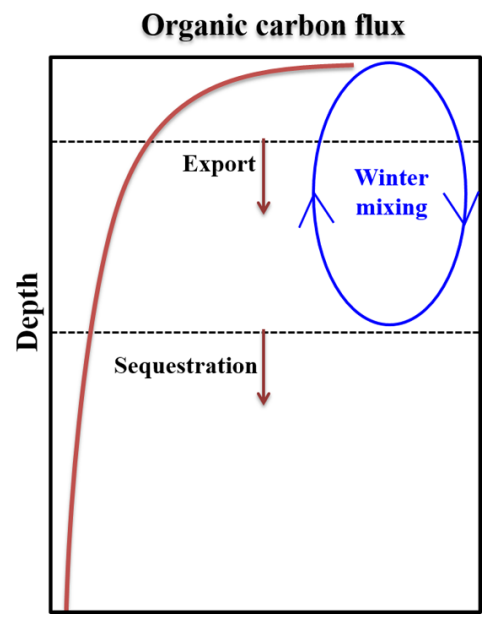

Figure 3. The iron hypothesis, as suggested by Martin (1990). (a) Effectiveness of the biological pump under normal conditions. (b) Effectiveness of the biological pump following iron enrichment (modified from Sarmiento and Gruber, 2006). (c) Schematic diagram of the decrease in the downward flux of organic carbon as a function of depth in the water column (modified from Lampitt et al., 2008). OM is organic matter and DIC is dissolved inorganic carbon.

Dust inputs are generally regarded as a major natural iron source for ocean fertilization, and Martin (1990) hypothesized that during the LGM increased dust inputs relieved iron limitation and, thereby, substantially enhanced the biological pump in HNLC regions, particularly in the SO (Fig. 3b). Since Martin's hypothesis was first published, there has been an enormous interest in ocean iron fertilization (OIF) because only a small amount of iron $(\mathrm{C}: \mathrm{Fe}$ ratios $=100000: 1$, Anderson and Morel, 1982) is needed to stimulate a strong phytoplankton response. Therefore, much of the investigative focus has centered on the artificial addition of iron to HNLC regions as a means of enhancing carbon fixation and subsequent export via the biological pump (ACE CRC, 2008).

To test Martin's hypothesis, six natural OIF (nOIF) and 13 artificial OIF (aOIF) experiments have been performed to date in the subtropical North Atlantic (NA), EP, subarctic NP, and SO (Blain et al., 2007, 2015; Boyd et al., 2007; Pollard et al., 2009; Strong et al., 2009; Smetacek et al., 2012; Martin et al., 2013) (Fig. 4a and Table 1). These OIF experiments demonstrated, particularly for the SO, that PP could be significantly increased after iron addition (de Baar et al., 2005; Boyd et al., 2007). However, for aOIF to be considered as a useful geoengineering approach (IPCC, 2007), in the long run, the most critical issue is the effectiveness of aOIF: that is, whether a significant portion of the organic carbon produced by aOIF in the surface waters is exported below the winter mixed layer depth (MLD) to intermediate-deep layers for long-term ( 1000 years) storage (Fig. 3c) (Lampitt et al., 2008). A high carbon export was observed in the nOIF experiments in the SO near the Kerguelen Plateau and Crozet Islands (Blain et al., 2007; Pollard et al., 2009). However, no significant increase in carbon exports has been detected during any aOIF experiments (de Baar et al., 2005; Boyd et al., 2007), except for the SO European Iron Fertilization Experiment, EIFEX (Smetacek et al., 2012). The results of these experiments, as well as the potential side effects (e.g., production of climate-relevant gases and development of hypoxia) (Fuhrman and Capone, 1991), have been scientifically debated amongst those who support and oppose aOIF experimentation (Chisholm et al., 2001; Johnson and Karl, 2002; Lawrence, 2002; Buesseler and Boyd, 2003; Smetacek and Naqvi, 2008; Williamson et al., 2012). A legal framework has been put in place to prevent venture capitalists from deploying large-scale OIF in any international waters because of the potential threat of commercialization and large-scale damage inflicted on the environment by private entities motivated primarily by profit. No other marine scientific institutions are willing to take up the challenge of carrying out new experiments due to the fear of negative publicity. Consequently, inaction on the part of scientists might be an incentive for others to go ahead with illegal experiments as happened off Canada in 2012 (e.g., the 2012 Haida Gwaii Iron Dump off the west coast of Canada).

In the context of increasing global (social-politicaleconomic) concerns associated with rapid climate change, it is necessary to examine the validity and usefulness of aOIF experimentation as a climate change mitigation strategy. Furthermore, aOIF experiments have provided insights into the structure and function of pelagic ecosystems that cannot be acquired from observational cruises alone. Non-OIF observations provide an assortment of snapshots from which only an incomplete image of the processes involved can be rendered, 


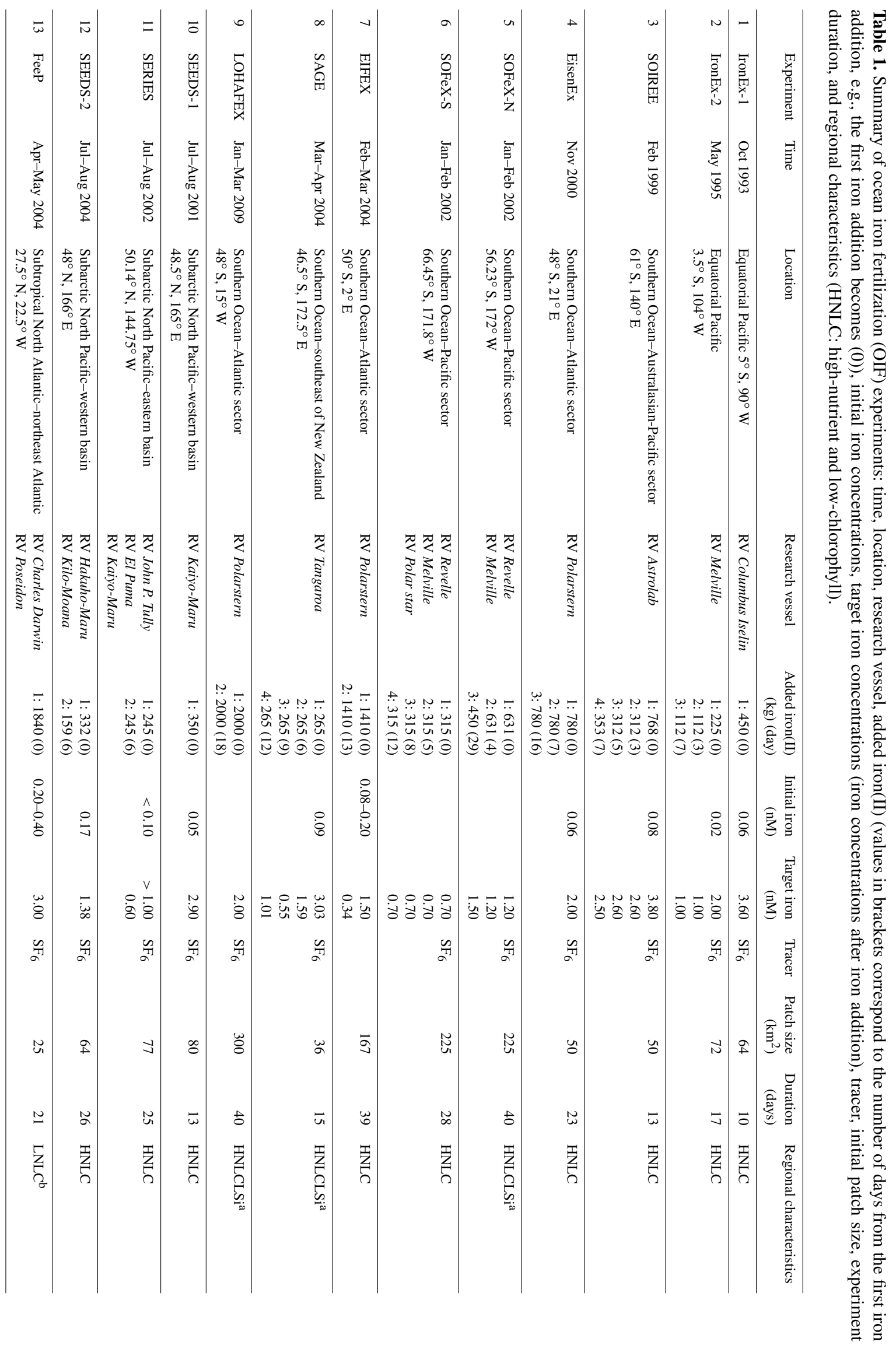




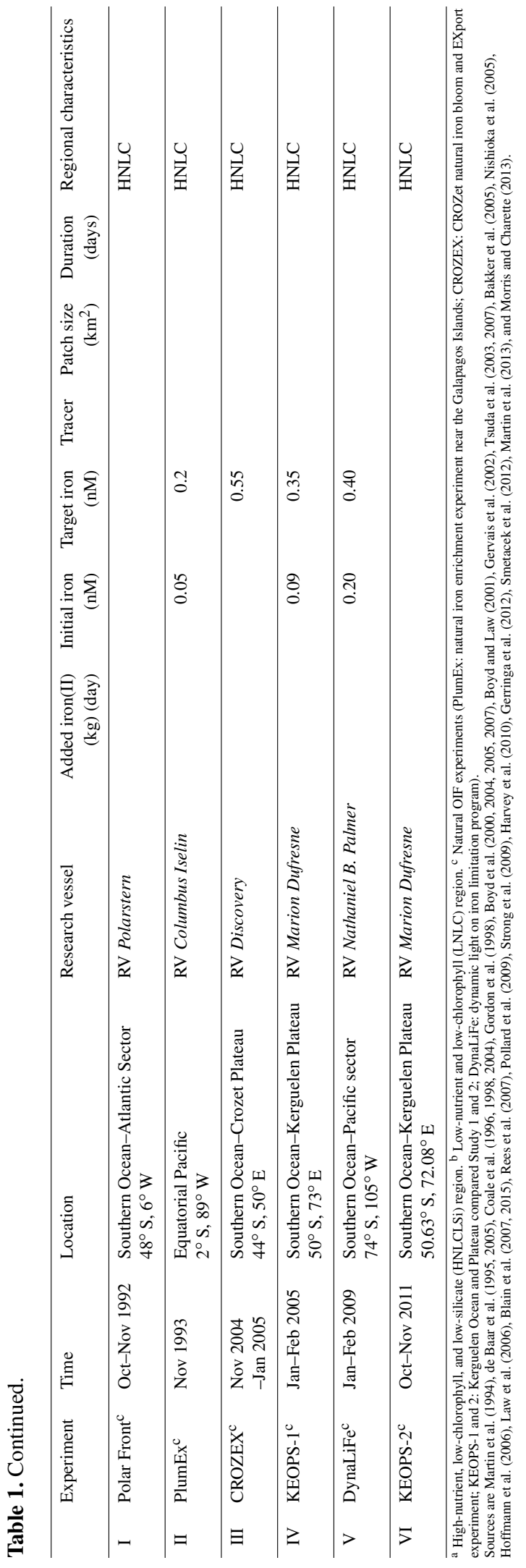

(a)

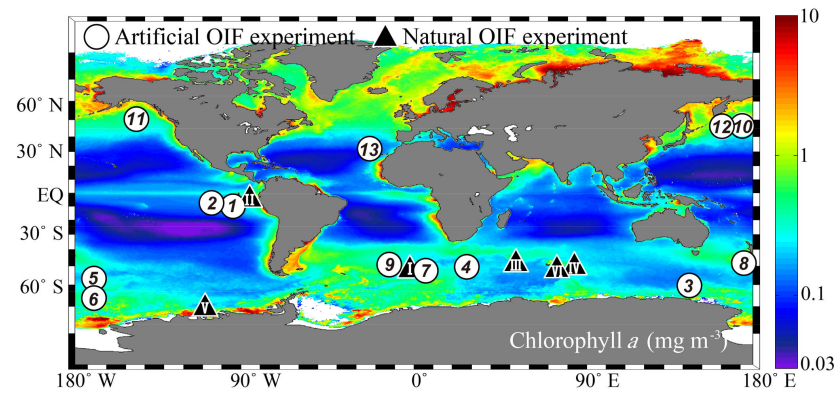

(b) Surface

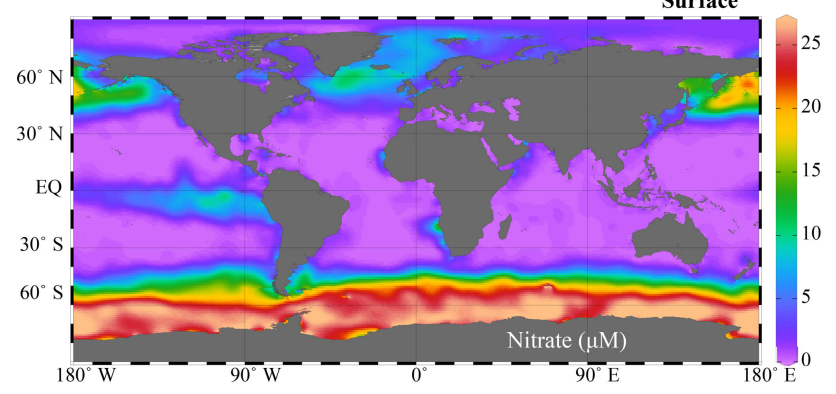

(c)
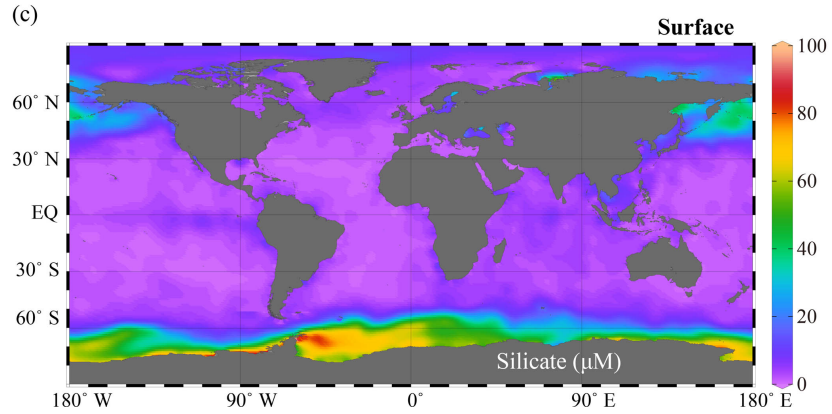

Figure 4. Global annual distribution of surface (a) chlorophyll concentrations $\left(\mathrm{mg} \mathrm{m}^{-3}\right),(\mathbf{b})$ nitrate concentrations $(\mu \mathrm{M})$, and (c) silicate concentrations $(\mu \mathrm{M})$. The chlorophyll $a$ concentration distribution was obtained from the Aqua MODIS chlorophyll $a$ composite from July 2002 to February 2016 (https://oceancolor.gsfc. nasa.gov/cgi/13, last access: 6 September 2018); nitrate and silicate were obtained from the World Ocean Atlas 2013 dataset (https: //odv.awi.de/en/data/ocean/world-ocean-atlas-2013, last access: 6 September 2018) and plotted using Ocean Data View (Schlitzer, 2017). The white circles indicate the locations of 13 artificial ocean iron fertilization (aOIF) experiments and the black triangles indicate the locations of six natural OIF (nOIF) experiments. Note that the numbers indicate the order of the aOIF experiments and the roman numerals indicate the order of the nOIF experiments (see Table 1).

while OIF experiments provide time-ordered focused frames allowing one to directly follow changes triggered by addition of an important limiting nutrient (i.e., iron) (Smetacek, 2018). That being said, it is necessary to plan and carry out the next aOIF experiments within the framework of international law. Therefore, the purpose of this paper is to (1) provide a thorough overview of the aOIF experiments conducted over the last 25 years; (2) discuss aOIF-related important unanswered questions, including carbon export mea- 
surement methods, potential side effects, and international law; (3) suggest considerations for the design of future aOIF experiments to maximize the effectiveness of the technique and begin to answer open questions; and (4) introduce design guidelines for a future Korean Iron Fertilization Experiment in the Southern Ocean (KIFES).

\section{Past: overview of previous aOIF experiments}

A total of 13 aOIF experiments have been conducted in the following areas: 12 experiments were conducted in the three main HNLC (i.e., nitrate $>\sim 10 \mu \mathrm{M}$ ) regions: two in the EP, three in the subarctic NP, and seven in the SO (Table 1, Fig. 4a and b). One experiment was conducted in the subtropical NA, known to be a low-nutrient and low-chlorophyll (LNLC) (i.e., nitrate $<1 \mu \mathrm{M}$ ) region. These aOIF experiments have been conducted with various objectives and multiple hypotheses to investigate the biogeochemical responses of ocean environments to artificial iron additions (Table 2). This overview of past aOIF experimentation begins in Sect. 2.1, with a presentation of the reasons why each experiment was performed and the main hypotheses (Table 2). The unique ocean conditions for the various experiments are described in Sect. 2.2. Iron addition and tracing methods are described in Sect. 2.3. The biogeochemical responses to the aOIF experiments are presented in Sect. 2.4, and finally the significant findings from these experiments are summarized in Sect. 2.5.

\subsection{Objectives and hypotheses of previous aOIF experiments}

\subsubsection{Equatorial Pacific}

Initially, Martin's hypothesis was supported by the results of laboratory and shipboard iron-enrichment bottle experiments (Hudson and Morel, 1990; Brand, 1991; Sunda et al., 1991; DiTullio et al., 1993; Hutchins et al., 1993). However, the extrapolation of these results based on bottle incubations that exclude higher trophic levels has been strongly criticized due to possible underestimates in grazing rates and other bottle effects. To deal with these issues, in situ iron fertilization experiments at the whole-ecosystem level are required. Under the hypothesis that aOIF would increase phytoplankton productivity by relieving iron limitations on phytoplankton in HNLC regions, the first aOIF experiment, the iron enrichment experiment (IronEx-1), was conducted over 10 days in October 1993 in the EP where high light intensity and temperatures would promote rapid phytoplankton growth (Table 1 and Fig. 4a) (Martin et al., 1994; Coale et al., 1998).

However, the magnitude of the biogeochemical responses in IronEx-1 was not as large as expected (Martin et al., 1994). Four hypotheses were advanced to explain the weak responses observed: (1) the possibility of unforeseen micronutrient (e.g., zinc, cadmium, and manganese) or macronutri- ent (e.g., silicate) limitations, (2) the short residence time of bioavailable iron in the surface patch due to colloidal aggregation and/or sinking of larger particles containing iron, (3) insufficient light brought about by subduction of the patch, and (4) high grazing pressure by zooplankton (Martin et al., 1994; Cullen, 1995; Coale et al., 1996; Gordon et al., 1998). To test the four hypotheses, a second aOIF experiment, IronEx-2, was conducted in May 1995 (Coale et al., 1996). The IronEx-2 research cruise investigated the same area for a longer period (17 days), providing more time to collect information about the biogeochemical, physiological, and ecological responses to the aOIF.

\subsubsection{Southern Ocean}

The SO plays an important role in intermediate and deepwater formation and has the greatest potential of any of the major ocean basins for carbon sequestration associated with artificial iron addition (Martin, 1990; Sarmiento and Orr, 1991; Cooper et al., 1996; Marshall and Speer, 2012). It is known as the largest HNLC region in the world ocean and models simulating aOIF have predicted that, among all HNLC regions, the effect of OIF on carbon sequestration is greatest in the SO (Sarmiento and Orr, 1991; Aumont and Bopp, 2006). However, a simple extrapolation of the IronEx2 results to the SO was not deemed appropriate because of the vastly different environmental conditions (Coale et al., 1996); therefore, based on the lessons from the EP experiments, several aOIF experiments were carried out in the SO (Frost, 1996; Boyd et al., 2000; Smetacek, 2001; Coale et al., 2004; Harvey et al., 2010; Smetacek et al., 2012; Martin et al., 2013). To test the roles of iron and light availability as key factors controlling phytoplankton dynamics, community structure, and grazing in the SO, the Southern Ocean Iron Release Experiment (SOIREE) (Table 1 and Fig. 4a), the first in situ aOIF experiment performed in the SO, took place in February 1999 (13 days) in the Australasian-Pacific sector (Boyd et al., 2000).

The following year, a second aOIF experiment in the SO, EisenEx (Eisen means iron in German), was performed in November within an Antarctic Circumpolar Current eddy in the Atlantic sector (Smetacek, 2001; Gervais et al., 2002). This region is considered to have a relatively high iron supply, which is supported by dust inputs and possibly icebergs (de Baar et al., 1995; Quéguiner et al., 1997; Smetacek et al., 2002). EisenEx was designed to test how atmospheric dust, an important source of iron in ocean environments, might have led to a dramatic increase in ocean productivity during the LGM due to the relief of iron-limiting conditions for phytoplankton growth (Smetacek, 2001; Abelmann et al., 2006).

In addition to iron availability, the supply of silicate is also considered to be an important factor controlling PP in the SO. Silicate-requiring diatoms, which are large-sized phytoplankton, play an important role in the biological pump and are responsible for $\sim 75 \%$ of the annual PP in the SO 
Table 2. Summary of artificial ocean iron fertilization (aOIF) experiments: objectives, significant results, and limitations.

\begin{tabular}{|c|c|c|c|c|}
\hline & Experiment & Objectives & Significant results & Limitations \\
\hline 1 & IronEx-1 & $\begin{array}{l}\text { - To test the hypothesis that artificial } \\
\text { iron addition will increase phyto- } \\
\text { plankton productivity by relieving } \\
\text { the iron limitation of phytoplankton } \\
\text { in high-nutrient, low-chlorophyll re- } \\
\text { gions }\end{array}$ & $\begin{array}{l}\text { - Small responses in the } p \mathrm{CO}_{2} \\
\text { concentrations, } F_{\mathrm{V}} / F_{\mathrm{m}} \text { ratio, } \\
\text { chlorophyll } a \text { concentration, and } \\
\text { primary production }(\mathrm{PP}) \\
\text { - Insignificant changes in nutrients }\end{array}$ & $\begin{array}{l}\text { - Subduction of the fertilized patch } \\
\text { - Single iron addition } \\
\text { - Insufficient experimental periods } \\
\text { to observe the full phases of bio- } \\
\text { geochemical responses from the } \\
\text { onset to termination after iron ad- } \\
\text { ditions } \\
\text { - Micro- or macronutrient limita- } \\
\text { tions }\end{array}$ \\
\hline 2 & IronEx-2 & $\begin{array}{l}\text { To test four hypotheses that were ad- } \\
\text { vanced to explain the weak biogeo- } \\
\text { chemical response observed during } \\
\text { IronEx-1 }\end{array}$ & $\begin{array}{l}\text { - Dramatic changes in biogeo- } \\
\text { chemical responses; close to sup- } \\
\text { port for Martin's hypothesis } \\
\text { - Taxonomic shift toward diatom- } \\
\text { dominated phytoplankton com- } \\
\text { munities }\end{array}$ & $\begin{array}{l}\text { - No export flux measurements in } \\
\text { the deep ocean } \\
\text { - Insufficient experimental dura- } \\
\text { tion }\end{array}$ \\
\hline 3 & SOIREE & $\begin{array}{l}\text { - To test the iron hypothesis in the } \\
\text { Southern Ocean }\end{array}$ & $\begin{array}{l}\text { - Diatom-dominated bloom } \\
\text { - No measurable change in carbon } \\
\text { export }\end{array}$ & $\begin{array}{l}\text { - Insufficient experimental dura- } \\
\text { tion }\end{array}$ \\
\hline 4 & EisenEx & $\begin{array}{l}\text { To test the hypothesis that atmo- } \\
\text { spheric dust inputs might have led } \\
\text { to a dramatic increase in ocean pro- } \\
\text { ductivity during the Last Glacial } \\
\text { Maximum due to the relief of iron- } \\
\text { limited conditions for phytoplank- } \\
\text { ton growth }\end{array}$ & $\begin{array}{l}\text { - Diatom-dominated bloom } \\
\text { - No clear differences in carbon } \\
\text { flux between in patch and outside } \\
\text { patch }\end{array}$ & $\begin{array}{l}\text { - Light limitation by storms } \\
\text { - Insufficient experimental dura- } \\
\text { tion }\end{array}$ \\
\hline 5 & SOFeX-N & $\begin{array}{l}\text { - To address the potential for iron and } \\
\text { silicate interactions to regulate the } \\
\text { diatom bloom }\end{array}$ & $\begin{array}{l}\text { - Remarkable increase in diatom } \\
\text { biomass } \\
\text { - Observation of large export flux } \\
\text { event with transmissometers }\end{array}$ & $\begin{array}{l}\text { - Entrainment of dissolved silicate } \\
\text { into the fertilized patch by physi- } \\
\text { cal mixing } \\
\text { - No direct measurement of export } \\
\text { fluxes with sediment traps }\end{array}$ \\
\hline 6 & SOFeX-S & $\begin{array}{l}\text { - To address the potential for iron and } \\
\text { silicate interactions to regulate the } \\
\text { diatom bloom }\end{array}$ & $\begin{array}{l}\text { - Significantly enhanced export } \\
\text { fluxes out of the mixed layer } \\
\text { (ML), but similar to those for } \\
\text { natural blooms }\end{array}$ & $\begin{array}{l}\text { - Insufficient experimental dura- } \\
\text { tion }\end{array}$ \\
\hline 7 & EIFEX & $\begin{array}{l}\text { - To confirm that aOIF experiments } \\
\text { can increase export production }\end{array}$ & $\begin{array}{l}\text { - Observation of all the phases of } \\
\text { the phytoplankton bloom from } \\
\text { onset to termination } \\
\text { - Significant carbon export to } \\
\text { deeper layers (down to } 3000 \mathrm{~m} \text { ) } \\
\text { due to the formation of aggre- } \\
\text { gates with rapid sinking rates }\end{array}$ & \\
\hline 8 & SAGE & $\begin{array}{l}\text { - To determine the response of phyto- } \\
\text { plankton dynamics to iron addition } \\
\text { in high-nutrient, low-chlorophyll, } \\
\text { and low-silicate (HNLCLSi) regions } \\
\text { - To test the assumption that the re- } \\
\text { sponse of phytoplankton blooms to } \\
\text { artificial iron addition can be de- } \\
\text { tected by the enhanced air-sea ex- } \\
\text { changes of climate-relevant gases }\end{array}$ & $\begin{array}{l}\text { - No shift to a diatom-dominated } \\
\text { community } \\
\text { - No detection of fertilization- } \\
\text { induced export }\end{array}$ & $\begin{array}{l}\text { - High dilution rate by small patch } \\
\text { size }\end{array}$ \\
\hline
\end{tabular}


Table 2. Continued.

\begin{tabular}{|c|c|c|c|c|}
\hline & Experiment & Objectives & Significant results & Limitations \\
\hline 9 & LOHAFEX & $\begin{array}{l}\text { - To trace the fate of iron- } \\
\text { stimulated phytoplankton blooms } \\
\text { and deep carbon export in } \\
\text { HNLCLSi regions }\end{array}$ & $\begin{array}{l}\text { - Observation of all the phases of } \\
\text { the phytoplankton bloom from } \\
\text { onset to termination } \\
\text { - No shift to a diatom-dominated } \\
\text { community } \\
\text { - No detection of fertilization- } \\
\text { induced export } \\
\text { - High grazing pressure }\end{array}$ & \\
\hline 10 & SEEDS-1 & $\begin{array}{l}\text { - To investigate the relation- } \\
\text { ship between phytoplankton } \\
\text { biomass/community and dust } \\
\text { deposition in the subarctic North } \\
\text { Pacific } \\
\text { - To investigate changes in phyto- } \\
\text { plankton composition and verti- } \\
\text { cal carbon flux }\end{array}$ & $\begin{array}{l}\text { - A shift from oceanic diatoms to } \\
\text { fast-growing neritic ones } \\
\text { - The largest changes in biogeo- } \\
\text { chemical parameters of all aOIF } \\
\text { experiments } \\
\text { - No detection of large carbon ex- } \\
\text { port flux }\end{array}$ & $\begin{array}{l}\text { - Single iron addition } \\
\text { - Insufficient experimental dura- } \\
\text { tion }\end{array}$ \\
\hline 11 & SERIES & $\begin{array}{l}\text { - To compare the response of phy- } \\
\text { toplankton in the eastern subarc- } \\
\text { tic with that in the western sub- } \\
\text { arctic ecosystem } \\
\text { - To investigate the most signifi- } \\
\text { cant factor that controls the be- } \\
\text { ginning to the ending of the } \\
\text { phytoplankton bloom induced by } \\
\text { iron addition }\end{array}$ & $\begin{array}{l}\text { - Observation of all phases of the } \\
\text { phytoplankton bloom from onset } \\
\text { to termination } \\
\text { - No significant increases in export } \\
\text { fluxes below the ML } \\
\text { - High bacterial remineralization } \\
\text { and mesozooplankton grazing } \\
\text { pressure }\end{array}$ & \\
\hline 12 & SEEDS-2 & $\begin{array}{l}\text { - To investigate the most signifi- } \\
\text { cant factor that controls the be- } \\
\text { ginning to the ending of the } \\
\text { phytoplankton bloom induced by } \\
\text { iron addition }\end{array}$ & $\begin{array}{l}\text { - Observation of all phases of the } \\
\text { phytoplankton bloom from onset } \\
\text { to termination } \\
\text { - No shift to a diatom-dominated } \\
\text { community } \\
\text { - No significant increases in export } \\
\text { fluxes } \\
\text { - Extensive copepod grazing }\end{array}$ & \\
\hline 13 & FeeP & $\begin{array}{l}\text { - To investigate the impact of iron } \\
\text { and phosphate co-limitation on } \\
\text { PP }\end{array}$ & $\begin{array}{l}\text { - Increases in picophytoplankton } \\
\text { abundances }\end{array}$ & \\
\hline
\end{tabular}

(Tréguer et al., 1995). The silicate concentrations in the SO show a decreasing northward gradient, in particular, on either side of the Antarctic Polar Front (PF), with low silicate concentrations $(<5 \mu \mathrm{M})$ in the sub-Antarctic waters north of the $\mathrm{PF}\left(<61^{\circ} \mathrm{S}\right)$ and high silicate concentrations $(>60 \mu \mathrm{M})$ to the south of the PF (Fig. 4c). Therefore, to address the impact of iron and silicate on phytoplankton communities and export, two aOIF experiments were conducted during JanuaryFebruary 2002 in two distinct regions: the Southern Ocean iron experiment north $(\mathrm{SOFeX}-\mathrm{N})$ and south $(\mathrm{SOFeX}-\mathrm{S})$ of the PF (Table 1) (Coale et al., 2004; Hiscock and Millero,
2005). Two years later, the Surface Ocean-Lower Atmosphere Study (SOLAS) Air-Sea Gas Exchange (SAGE) experiment was conducted during March-April 2004 (15 days) in sub-Antarctic waters, which are typically HNLC with low silicate concentrations (HNLCLSi). The aim was to determine the response of phytoplankton dynamics to iron addition in an HNLCLSi region (Fig. 4c) (Law et al., 2011). SAGE was designed with the assumption that the response of phytoplankton blooms to aOIF could be detected by enhanced air-sea exchanges of climate-relevant gases (e.g., 
$\mathrm{CO}_{2}$ and dimethyl sulfide, DMS) (Harvey et al., 2010; Law et al., 2011).

These early aOIF experiments resulted in clear increases in phytoplankton biomass and PP, but the impact on export production (i.e., carbon export from the surface waters to below the winter MLD) was not evident (Fig. 3c) (de Baar et al., 2005; Boyd et al., 2007). To determine if aOIF could increase export production, EIFEX was carried out in the closed core of a cyclonic eddy near the PF during the austral summer of 2004 (Fig. 5). Because it was designed to investigate the termination of a bloom and resulting export production, EIFEX was much longer (39 days) than earlier experiments (mean $\pm \mathrm{SD}=22 \pm 10$ days; $\mathrm{SD}$ represents standard deviation) (Smetacek et al., 2012).

Of similar duration, the Indo-German iron fertilization experiment (LOHAFEX; Loha means iron in Hindi) was conducted during January-March 2009 (40 days), also in a PF cyclonic eddy in HNLCLSi waters (Smetacek and Naqvi, 2010; Martin et al., 2013).

\subsubsection{Subarctic North Pacific}

The subarctic NP shows a strong longitudinal gradient in aeolian dust deposition (i.e., high dust deposition in the west, but low in the east) (Duce and Tindale, 1991; Tsuda et al., 2003; Takeda and Tsuda, 2005), which is different from the other two HNLC regions (i.e., EP and SO). To investigate the relationship between the phytoplankton biomass/community and dust deposition, the Subarctic Pacific iron Experiment for Ecosystem Dynamics Study 1 (SEEDS-1) was conducted in July-August 2001 (13 days) in the western subarctic gyre (Tsuda et al., 2003, 2005). In 2004, the experiment was repeated (SEEDS-2) in almost the same location and season. In the intervening year, the Subarctic Ecosystem Response to Iron Enrichment Study (SERIES) was performed in JulyAugust 2002 (25 days) in the Gulf of Alaska (representing the eastern subarctic gyre ecosystem) to compare the response of phytoplankton in this area with that in the western subarctic (Boyd et al., 2004, 2005). The SEEDS-1 and 2 experiments focused on changes in phytoplankton composition, vertical carbon flux, and climate-relevant gas production stimulated by artificial iron addition (Tsuda et al., 2005, 2007). The main objective of SEEDS-2 and SERIES was to determine the most significant factor (i.e., nutrient supply and/or grazing) controlling the iron-induced phytoplankton bloom from its beginning to its end (Tsuda et al., 2007; Boyd et al., 2004).

\subsubsection{Subtropical North Atlantic}

Unlike HNLC regions, PP in LNLC regions, which are predominantly occupied by $\mathrm{N}_{2}$ fixers, is generally co-limited by phosphate and iron (Mills et al., 2004). To investigate the impact of iron and phosphate co-limitation on PP, the in situ phosphate and iron addition experiment (FeeP) was

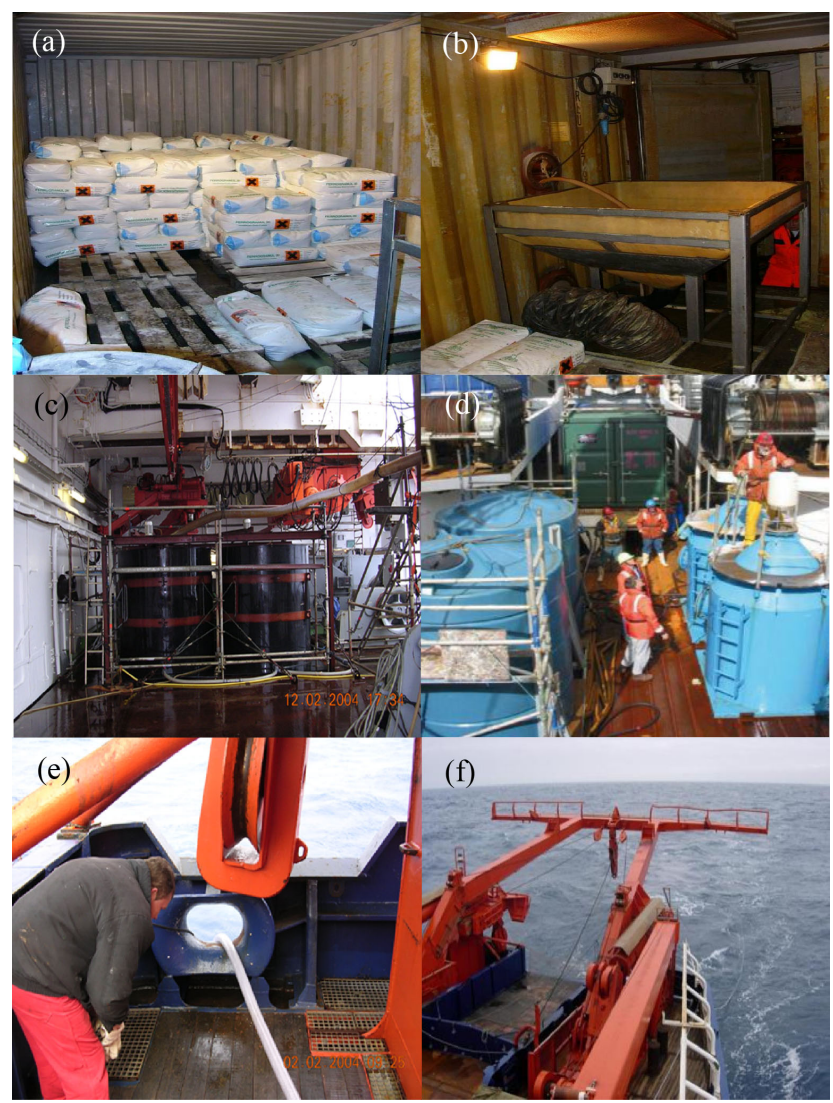

Figure 5. Photographs of the iron addition procedure (a-f) taken during the European Iron Fertilization Experiment (EIFEX), Surface Ocean-Lower Atmosphere Study (SOLAS) Air-Sea Gas Exchange (SAGE), and Indo-German iron fertilization experiment (LOHAFEX). (a) Iron(II) sulfate bags. (b) The funnel used to pour iron and hydrochloric acid. (c) Tank system used for mixing iron(II) sulfate, hydrochloric acid, and seawater (Smetacek, 2015). (d) Preparation for release: the deck of RV Tangaroa with the iron tanks on the left and the $\mathrm{SF}_{6}$ tracer tanks on the right (photo: Matt Walkington) (https://www.niwa.co.nz/ coasts-and-oceans/research-projects/sage, last access: 6 September 2018). (e) Outlet pipe connected to the tank system. (f) Pumping iron into the prop wash during EIFEX (Smetacek, 2015).

conducted by adding both phosphate and iron in a LNLC region of the subtropical NA during April-May 2004 (21 days) (Rees et al., 2007). The location of the subtropical NA experiment corresponded to a typical LNLC region (Fig. 4a and b, Tables 3 and 4) with low nutrients (nitrate: $<0.01 \mu \mathrm{M}$, phosphate: $\sim 0.01 \mu \mathrm{M}$, and iron: $<0.4 \mathrm{nM})$ and chlorophyll $a$ $\left(<0.1 \mathrm{mg} \mathrm{m}^{-3}\right)$ conditions much lower than other experimental sites. The FeeP experiment reported that picoplankton $(0.2-2.0 \mu \mathrm{m})$ abundances increased after iron and phosphate additions (Rees et al., 2007); however, no other details on the biogeochemical response to aOIF in FeeP have been reported. This experiment will, therefore, not be discussed further. 


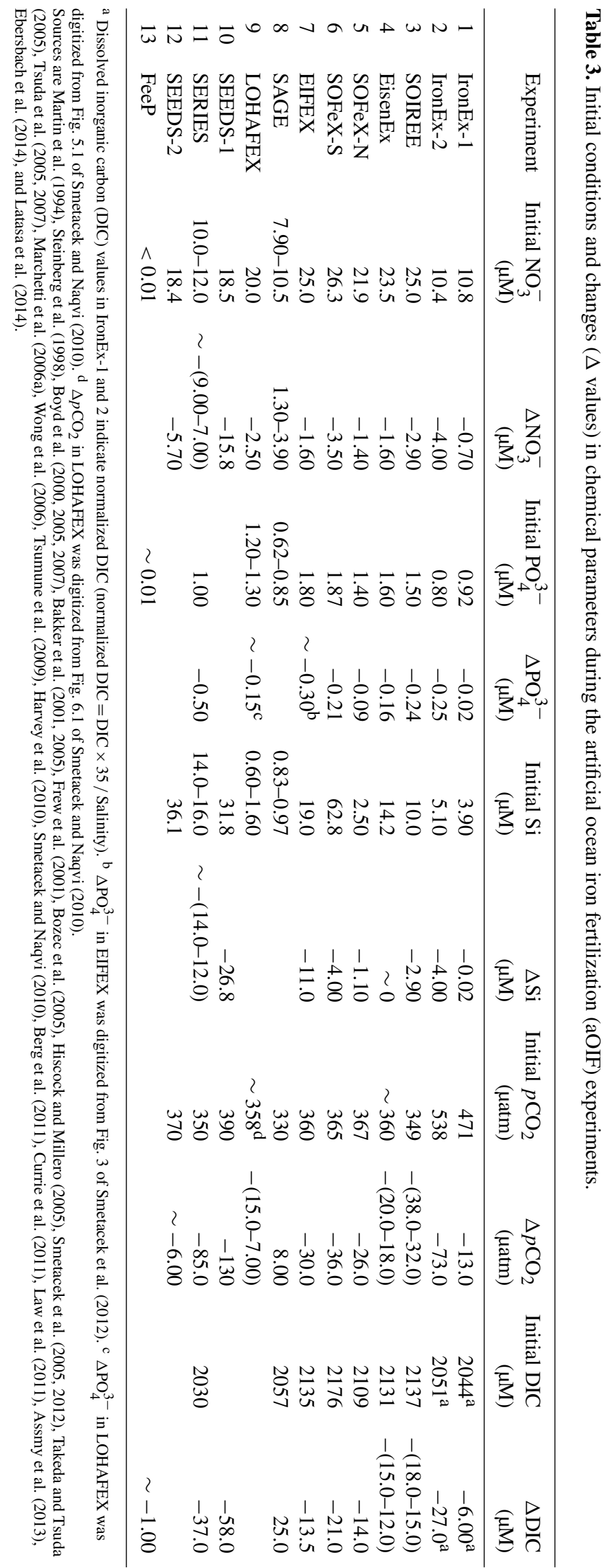


(a)

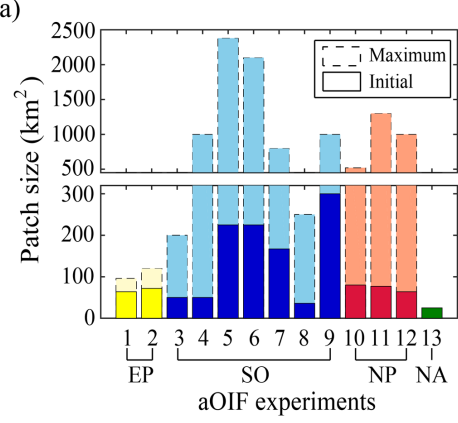

(c)

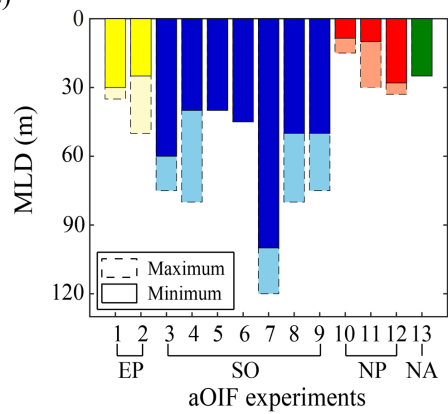

(e)

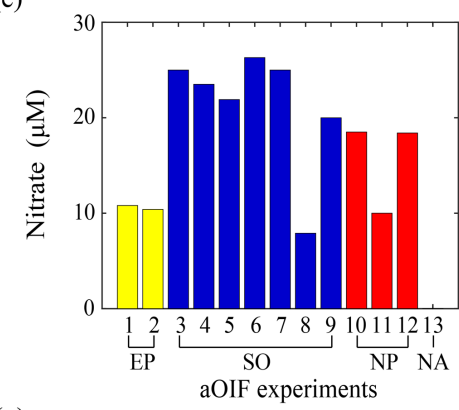

(g)

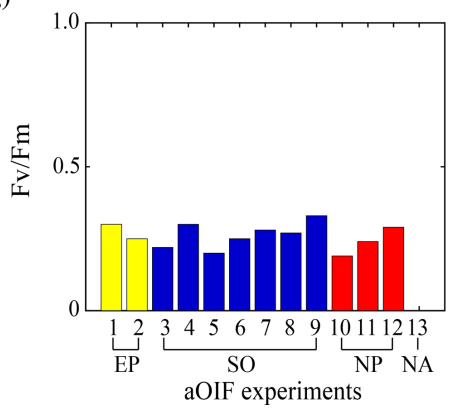

(b)

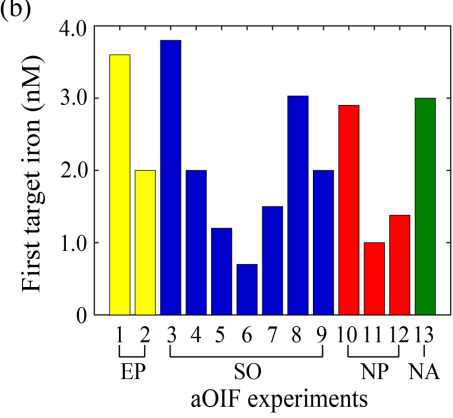

(d)

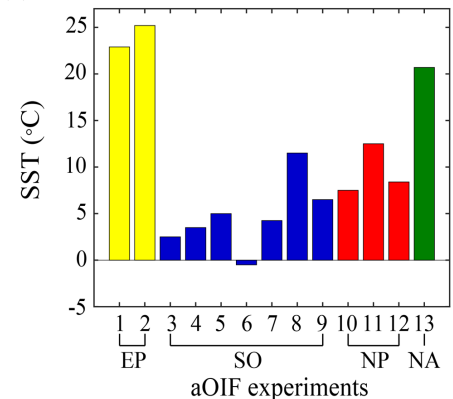

(f)

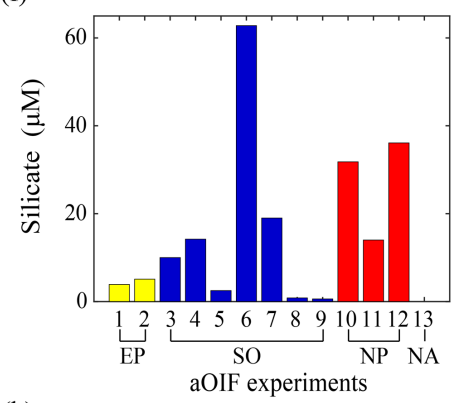

(h)

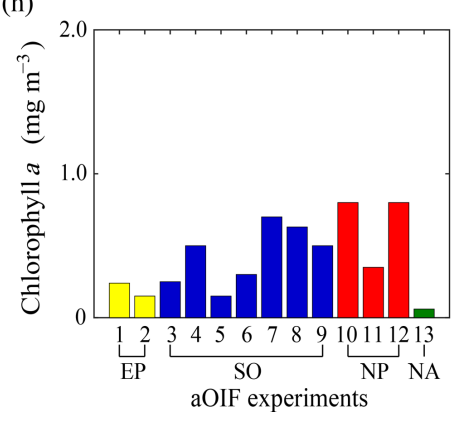

Figure 6. (a) Maximum (bar with dotted line) and initial (bar with solid line) patch size $\left(\mathrm{km}^{2}\right)$ during artificial ocean iron fertilization (aOIF) experiments. (b) First target iron concentrations (nM). (c) Maximum (bar with dotted line) and minimum (bar with solid line) mixed layer depth (MLD, m) during aOIF experiments. (d) Initial sea surface temperature (SST, $\left.{ }^{\circ} \mathrm{C}\right)$. (e) Initial nitrate concentrations $(\mu \mathrm{M})$. (f) Initial silicate concentrations $(\mu \mathrm{M})$. (g) Initial $F_{\mathrm{V}} / F_{\mathrm{m}}$ ratios. (h) Initial chlorophyll $a$ concentrations $\left(\mathrm{mg} \mathrm{m}^{-3}\right)$. Note that the numbers on the $x$ axis indicate the order of aOIF experiments as given in Fig. 4 and Table 1 and are grouped according to ocean basins: equatorial Pacific (EP) (yellow bar), Southern Ocean (SO) (blue bar), subarctic North Pacific (NP) (red bar), and subtropical North Atlantic (NA) (green bar). Sources are Kolber et al. (1994), Martin et al. (1994), Behrenfeld et al. (1996), Coale et al. (1996, 1998, 2004), Steinberg et al. (1998), Boyd et al. (2000, 2005, 2007), Boyd and Law (2001), Gall et al. (2001a), Gervais et al. (2002), Law et al. (2003, 2006, 2011), Tsuda et al. (2003, 2005, 2007), Turner et al. (2004), Bakker et al. (2005), Bozec et al. (2005), de Baar et al. (2005), Hiscock and Millero (2005), Takeda and Tsuda (2005), Tsumune et al. (2005, 2009), Marchetti et al. (2006a), Rees et al. (2007), Suzuki et al. (2009), Harvey et al. (2010), Smetacek and Naqvi (2010), Berg et al. (2011), Hadfield (2011), Peloquin et al. (2011b), Smetacek et al. (2012), Thiele et al. (2012), Martin et al. (2013), Ebersbach et al. (2014), and Latasa et al. (2014). 


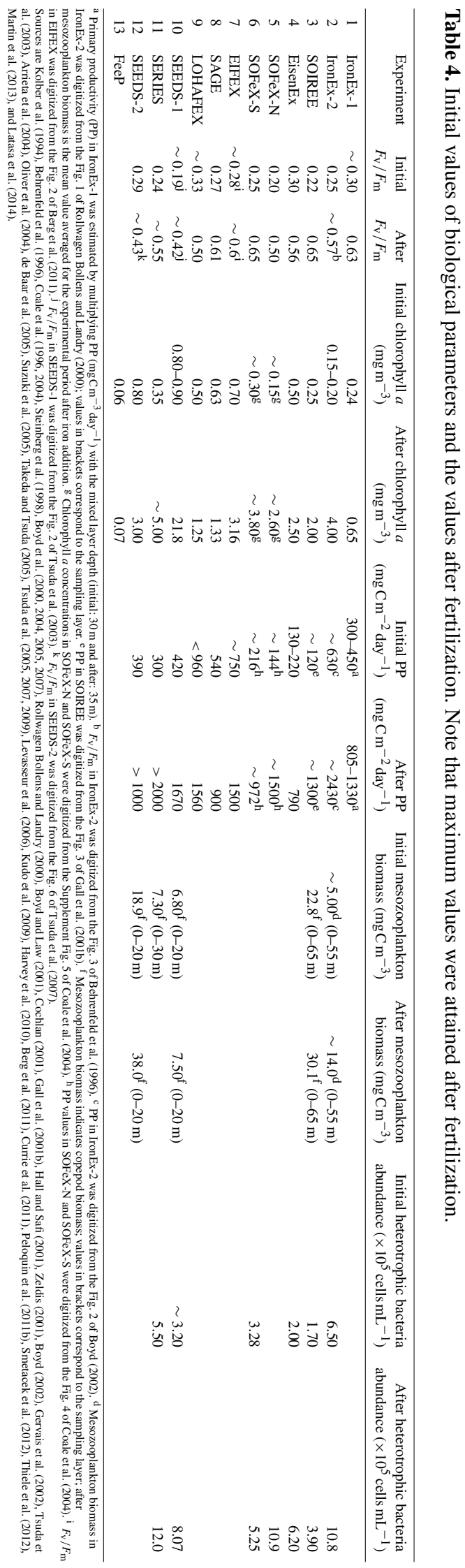

\subsection{Environmental conditions prior to iron addition}

The initial environment $(\sim 1-7$ days before iron addition) can affect the outcome of an aOIF experiment, and the experiments described above were conducted under a wide range of physical and biogeochemical conditions. Below we consider the similarities and differences in these environments according to the physical and biogeochemical properties of the sites (Coale et al., 1998, 2004; Steinberg et al., 1998; Bakker et al., 2001; Boyd and Law, 2001; Gervais et al., 2002; Boyd et al., 2005; Takeda and Tsuda, 2005; Tsuda et al., 2007; Cisewski et al., 2008; Harvey et al., 2010; Cavagna et al., 2011) (Fig. 6, Tables 3 and 4).

\subsubsection{Equatorial Pacific}

The first two aOIF experiments, IronEx-1 and IronEx2 , which were both conducted in the EP, were performed in different seasons (i.e., IronEx-1: October, IronEx2: May). However, the initial surface physical conditions were similar, with warm temperatures $\left(24.1 \pm 1.2^{\circ} \mathrm{C}\right)$, high surface photosynthetic available radiation values $(\sim$ $\left.51.7 \pm 2.1 \mathrm{~mol} \mathrm{~m}^{-2} \mathrm{day}^{-1}\right)$, and shallow MLDs $(27.5 \pm 2.5 \mathrm{~m})$ (Fig. 6c and d) (Coale et al., 1996, 1998; Steinberg et al., 1998; de Baar et al., 2005).

The initial surface biogeochemical conditions were high nutrients (i.e., nitrate $=10.6 \pm 0.2 \mu \mathrm{M}$, phosphate $=0.86 \pm$ $0.06 \mu \mathrm{M}$, and silicate $=4.5 \pm 0.6 \mu \mathrm{M})$ and low chlorophyll $a$ concentrations $\left(0.2 \pm 0.05 \mathrm{mg} \mathrm{m}^{-3}\right)$ (Tables 3 and 4). The picophytoplankton community, including Synechococcus and Prochlorococcus, was dominant (Martin et al., 1994; Coale et al., 1996; Cavender-Bares et al., 1999). Initial surface nutrient concentrations were relatively low compared with other ocean basin aOIF sites (Table 3 and Fig. 6e). Initial photosynthetic quantum efficiency (i.e., $F_{\mathrm{v}} / F_{\mathrm{m}}$ ratio, where $F_{\mathrm{m}}$ is the maximum chlorophyll fluorescence yield and $F_{\mathrm{V}}$ is the difference between $F_{\mathrm{m}}$ and the minimum chlorophyll fluorescence yield) (Butler, 1978), which is widely used to determine the degree to which iron is the limiting nutrient for phytoplankton growth (the $F_{\mathrm{v}} / F_{\mathrm{m}}$ ratio ranges from 0.2 to 0.65 where conditions are less iron limited as $F_{\mathrm{v}} / F_{\mathrm{m}}$ approaches 0.65), was less than $\sim 0.3$ (Fig. 6g and Table 4), suggesting severe iron limitation (Behrenfeld et al., 1996; Barber and Hiscock, 2006; Aiken et al., 2008). In the EP, initial surface partial pressure of $\mathrm{CO}_{2}\left(p \mathrm{CO}_{2}\right)$ values were $504.5 \pm 33.5 \mu \mathrm{atm}$, which were much higher than those observed in the SO $(355.6 \pm 11.7 \mu \mathrm{atm})$ or the subarctic NP $(370.0 \pm 16.3 \mu \mathrm{atm})$ (Table 3) (Steinberg et al., 1998).

\subsubsection{Southern Ocean}

The initial physical conditions for the aOIF experiments in the SO (SOIREE, EisenEx, SOFeX-N, SOFeX-S, EIFEX, SAGE, and LOHAFEX) were very different from those found in the EP; MLDs were much deeper $(57.9 \pm 19.2 \mathrm{~m})$ 
(Fig. 6c) and sea surface temperature (SST) was much lower $\left(4.7 \pm 3.4^{\circ} \mathrm{C}\right.$ ) (Fig. 6d). During SOFeX-N and SOFeX-S, which were conducted along the same line of longitude, on either side of the $\mathrm{PF}$, there were distinct differences in SST: $5.0^{\circ} \mathrm{C}$ in SOFeX-N and $-0.5^{\circ} \mathrm{C}$ in SOFeX-S (Coale et al., 2004). SAGE was the northernmost of the aOIF experiments in the SO (Table 1) and, therefore, had the highest SST (11.5 ${ }^{\circ}$ C) (Fig. 6d) (Harvey et al., 2010).

The locations for the aOIF experiments were selected following preliminary surveys to confirm the HNLC conditions, i.e., based on satellite imagery, nutrient concentrations, and $F_{\mathrm{v}} / F_{\mathrm{m}}$. Initial nitrate concentrations ranged from $7.9 \mu \mathrm{M}$ (SAGE) to $26.3 \mu \mathrm{M}$ (SOFeX-S) (Fig. 6e and Table 3). Among the various aOIF HNLC experiment sites, the SO had the highest initial nitrate concentrations $(21.4 \pm 5.8 \mu \mathrm{M})$, while the EP had the lowest $(10.6 \pm 0.2 \mu \mathrm{M})$. Initial nitrate and phosphate concentrations at aOIF sites in the SO followed a latitudinal gradient, with higher values to the south of $50^{\circ} \mathrm{S}$ (nitrate: $24.6 \pm 1.6 \mu \mathrm{M}$ and phosphate: $1.6 \pm 0.2 \mu \mathrm{M}$ ) and lower values to the north (nitrate: $17.1 \pm 6.7 \mu \mathrm{M}$ and phosphate: $1.1 \pm 0.4 \mu \mathrm{M}$ ) (Table 3 , Figs. $4 \mathrm{~b}$ and $6 \mathrm{e}$ ). The full range of initial silicate concentrations has been covered by the various SO aOIF experiments, with values ranging from $\sim 1.0 \mu \mathrm{M}$ (SAGE) in the most northernmost site to $\sim 60 \mu \mathrm{M}$ (SOFeX-S) in the most southernmost (Table 3, Figs. $4 \mathrm{c}$ and $6 \mathrm{f}$ ). With the specific intent of investigating the co-limitation of iron and silicate, SOFeX-N, SAGE, and LOHAFEX were all conducted in HNLCLSi regions, with initial silicate concentrations less than $2.5 \mu \mathrm{M}$ (Figs. 4c and 6f) (Coale et al., 2004; Harvey et al., 2010; Martin et al., 2013; Ebersbach et al., 2014). Initial $p \mathrm{CO}_{2}$ values were low in the SO (355.6 $\pm 11.7 \mu \mathrm{atm})$, ranging from $330 \mu \mathrm{atm}$ (SAGE) to 367 ratm (SOFeX-N) (Table 3).

As in the EP, initial $F_{\mathrm{v}} / F_{\mathrm{m}}$ values were below $\sim 0.33$ (Table 4 and Fig. 6g), indicating severe iron limitation. Prior to iron addition, initial chlorophyll $a$ concentrations ranged from $\sim 0.15$ to $0.70 \mathrm{mg} \mathrm{m}^{-3}$. The maximum initial chlorophyll concentrations occurred in EIFEX, which started with a community dominated by diatoms (Hoffmann et al., 2006; Assmy et al., 2013), while the lowest initial chlorophyll concentrations occurred in SOFeX-N, with a community dominated by a nanoplankton $(2.0-20 \mu \mathrm{m})$, such as prymnesiophytes, pelagophytes, and dinoflagellates (Coale et al., 2004).

\subsubsection{Subarctic North Pacific}

The subarctic NP aOIF experiments (i.e., SEEDS-1, SEEDS2 , and SERIES) were performed in regions with high nitrate $(15.6 \pm 4.0 \mu \mathrm{M})$ and low chlorophyll $a$ concentrations $\left(0.7 \pm 0.2 \mathrm{mg} \mathrm{m}^{-3}\right)$ (Tables 3 and 4, Fig. 6e and h). Compared with the other aOIF experiments, these subarctic experiments had much higher initial silicate concentrations $(27.3 \pm 9.6 \mu \mathrm{M})$ (Table 3 and Fig. 6f) and shallower MLDs (Fig. 6c). Although SEEDS-1 and SEEDS-2 were conducted in almost the same location and season in the western basin
(Tsuda et al., 2007), the MLD in SEEDS-1 (8.5 m) was shallower than in SEEDS-2 (28 m) (Fig. 6c).

Unlike the latitudinal gradients seen in the aOIF experiments in the SO, there were longitudinal gradients in physical and biogeochemical properties in the subarctic NP experiments (Tables 3, 4, Figs. 4 and $6 \mathrm{~d}-\mathrm{h}$ ). Initial SSTs in the subarctic NP were lower in the western region $\left(7.5^{\circ} \mathrm{C}\right.$ in SEEDS- 1 and $8.4^{\circ} \mathrm{C}$ in SEEDS-2) than in the eastern region $\left(12.5^{\circ} \mathrm{C}\right.$ in SERIES) (Fig. 6d). Initial nutrient concentrations were much higher in the west (nitrate: $18.5 \pm 0.1 \mu \mathrm{M}$ and silicate: $34.0 \pm 2.2 \mu \mathrm{M}$ ) compared to the east (nitrate: $10 \mu \mathrm{M}$ and silicate: $14 \mu \mathrm{M}$ ) (Table 3, Figs. 4b, c and 6e, f). There was also a longitudinal gradient in chlorophyll $a$ concentrations, with relatively high values in the west (SEEDS1: $0.8 \mathrm{mg} \mathrm{m}^{-3}$ and SEEDS-2: $0.8 \mathrm{mg} \mathrm{m}^{-3}$ ) and low value in the east (SERIES: $0.35 \mathrm{mg} \mathrm{m}^{-3}$ ) (Fig. 6h). Before the first SEEDS-1 iron infusion, microphytoplanktons $(20-200 \mu \mathrm{m})$, such as the pennate diatom Pseudo-nitzschia turgidula, were dominant, whereas the areas for SERIES and SEEDS-2 were exclusively occupied by pico- and nanophytoplankton, such as Synechococcus and haptophytes (Boyd et al., 2005; Tsuda et al., 2005, 2007; Sato et al., 2009). Initial $F_{\mathrm{v}} / F_{\mathrm{m}}$ ratios in the subarctic NP aOIF experiments were $<0.3$, indicating a severe iron limitation (Fig. 6g).

\subsection{Iron addition and tracing methods}

\subsubsection{Iron addition}

Iron(II) and sulfate aerosols are ubiquitous in the atmosphere and, therefore, iron sulfate $\left(\mathrm{FeSO}_{4} \cdot \mathrm{H}_{2} \mathrm{O}\right)$, a common form of combined iron that enters the ocean environment via dust deposition, has been frequently regarded as a bioavailable iron source during glacial periods (Zhuang et al., 1992; Zhuang and Duce, 1993; Spolaor et al., 2013). Iron sulfate is a common inexpensive agricultural fertilizer that is relatively soluble in acidified seawater (Coale et al., 1998). Therefore, all aOIF experiments have been conducted by releasing commercial iron sulfate dissolved in acidified seawater into the propeller wash of a moving ship (Fig. 5), to ensure mixing with surface waters during iron additions.

In general, background dissolved iron concentrations in HNLC regions are $<0.2 \mathrm{nM}$ (Table 1 ). Iron-enrichment bottle incubation experiments performed in deck incubators using in situ seawater have indicated the maximum phytoplankton growth rates in response to iron additions of $1.0-2.0 \mathrm{nM}$ (Fitzwater et al., 1996). In aOIF experiments performed in the ocean, targeted iron concentrations within the ML have ranged between $\sim 1.0$ and $4.0 \mathrm{nM}$, depending on the site (Table 1 and Fig. 6b) (Martin et al., 1994; Coale et al., 1996, 2004; Boyd et al., 2000; Bowie et al., 2001; Tsuda et al., 2003; Nishioka et al., 2005; Law et al., 2006; Smetacek et al., 2012; Martin et al., 2013). If injected iron is well dispersed throughout the ML within $24 \mathrm{~h}$ by convective mixing (Martin and Chisholm, 1992), the amount of added iron re- 
quired to raise the background iron concentration to the target level can be calculated using a volume estimate (i.e., ironfertilized water patch area $\times$ MLD) (Watson et al., 1991). To minimize uncertainty between the first iron addition and phytoplankton response, aOIF experiments have involved multiple small iron injections to the surface waters in the study area at $\sim 0.4$ to $\sim 1.5 \mathrm{~km}$ intervals over a $1-2$-day period (Coale et al., 1998). The patch size fertilized by the first iron addition varied from $25 \mathrm{~km}^{2}$ (e.g., FeeP; iron(II) addition of $1840 \mathrm{~kg}$ ) to $300 \mathrm{~km}^{2}$ (e.g., LOHAFEX; iron(II) addition of $2000 \mathrm{~kg}$ ) and by the end of these experiments had spread to a maximum of $\sim 2400 \mathrm{~km}^{2}$ (Coale et al., 2004; Boyd et al., 2007; Strong et al., 2009; Martin et al., 2013) (Table 1 and Fig. 6a).

During the experiments, dissolved iron concentrations increased to the target $\sim 1.0-4.0 \mathrm{nM}$ (Table 1 and Fig. $6 \mathrm{~b}$ ), but decreased to background concentrations within days. The fast decrease in dissolved iron concentrations indicates that iron was horizontally dispersed and/or rapidly incorporated into particles. These processes occur more rapidly in warmer waters (ACE CRC, 2015). For example, the first aOIF experiment, IronEx-1, showed that the dissolved iron concentration rapidly decreased from 3.6 to $0.25 \mathrm{nM} \sim 4$ days after iron addition in the center of the fertilized patch, suggesting a limit to the level required for phytoplankton growth (Coale et al., 1998; Gordon et al., 1998). As a result, except for the single iron addition experiments of IronEx-1, SEEDS-1, and FeeP (Martin et al., 1994; Tsuda et al., 2003; Rees et al., 2007), most aOIF experiments have involved multiple iron additions at the patch center, to continuously derive the stimulation of phytoplankton during the experiments. These experiments included (two additions) EIFEX, SERIES, SEEDS2, and LOHAFEX (Boyd et al., 2005; Tsuda et al., 2007; Smetacek et al., 2012; Martin et al., 2013); (three additions) IronEx-2, EisenEx, and SOFeX-N (Coale et al., 1996, 2004; Gervais et al., 2002; Nishioka et al., 2005); and (four additions) SOIREE, SOFeX-S, and SAGE (Boyd et al., 2000; Coale et al., 2004; Bakker et al., 2005; Harvey et al., 2010) (Table 1).

\subsubsection{Tracing iron-fertilized patch}

To trace the iron-fertilized patch, aOIF experiments have used a combination of physical and biogeochemical approaches. All the aOIF experiments except EIFEX have used sulfur hexafluoride $\left(\mathrm{SF}_{6}\right)$ as a chemical tracer (Table 1) (Martin et al., 1994; de Baar et al., 2005; Smetacek et al., 2012). The $\mathrm{SF}_{6}$, which is not naturally found in oceanic waters, is a useful tracer for investigating physical mixing and advection-diffusion processes in the ocean environment due to its nontoxicity, biogeochemically inert characteristics, and low detection limit (Law et al., 1998). The injected $\mathrm{SF}_{6}$ is continuously monitored using gas chromatography with an electron capture detector system (Law et al., 1998; Tsumune et al., 2005). Usually only one $\mathrm{SF}_{6}$ injection is necessary be- cause background levels are generally extremely low in the ocean (<1.2 fM; f: femto-, 10-15) (Law et al., 1998, 2003; Boyd et al., 2004); however, in the SAGE experiment, with its higher mixing and lateral dilution, there were three injections (Harvey et al., 2010). Although these earlier experiments demonstrated that the injection of artificial $\mathrm{SF}_{6}$ is a useful technique for following iron-fertilized patches, $\mathrm{SF}_{6}$ can only be used for a limited period ( $\sim 2$ weeks) due to the loss at the surface through air-sea gas exchange (Law et al., 2006; Tsumune et al., 2009; Martin et al., 2013). Furthermore, caution is required because artificially high levels of $\mathrm{SF}_{6}$ injection may negatively impact the interpretation of low-level $\mathrm{SF}_{6}$ signals dissolved in seawater via air-sea exchange to estimate tracer-based water mass ages for understanding physical circulation (Fine, 2011). These techniques have been widely used to estimate anthropogenic carbon invasion as well as to understand ocean circulation in various ocean environments, with $\mathrm{SF}_{6}$ being an important timedependent tracer that has a well-recorded atmospheric history. Thus, continuous sampling systems, measuring biogeochemical parameters such as $F_{\mathrm{v}} / F_{\mathrm{m}}, p \mathrm{CO}_{2}$, and chlorophyll fluorescence, have also been used as an alternative means of following iron-fertilized patches (Gervais et al., 2002; Boyd et al., 2005; Tsuda et al., 2007; Harvey et al., 2010; Smetacek et al., 2012). The $F_{\mathrm{v}} / F_{\mathrm{m}}$ ratio displays a particularly rapid increase (within $24 \mathrm{~h}$ ) in response to a first iron addition (Kolber et al., 1994; Behrenfeld et al., 1996; Smetacek et al., 2012), suggesting that it is an easy and convenient tracer for following a fertilized patch.

In addition, surface-drifting buoys equipped with Argos or GPS systems have been successfully used to track the movement of fertilized patches along with biogeochemical tracers (Coale et al., 1998; Boyd and Law, 2001; Law et al., 2006; Martin et al., 2013). However, floats tend to drift out of the fertilized patches under strong wind forcing (Watson et al., 1991; Law et al., 1998; Stanton et al., 1998). NASA airborne oceanographic lidar and ocean-color satellites have also been employed to assess the large-scale effects of iron addition on surface chlorophyll in fertilized patches, as compared to surrounding regions (Martin et al., 1994; Westberry et al., 2013).

\subsection{Biogeochemical responses}

Biogeochemical responses to artificial iron addition, in particular, $F_{\mathrm{v}} / F_{\mathrm{m}}$ ratio, chlorophyll $a$, PP, nutrients, $\mathrm{CO}_{2}$ variables, and carbon export fluxes, are given in Tables 3-5 and Figs. 7-8. The results are important, as they have been used as a basis to determine whether the aOIF is effective. Here we address the biogeochemical response in each of the ocean basins to the aOIF experiments to date.

\subsubsection{Equatorial Pacific}

The IronEx-1 and 2 experiments, which were conducted in similar initial conditions (refer to Sect. 2.2.1), presented quite 
(a)

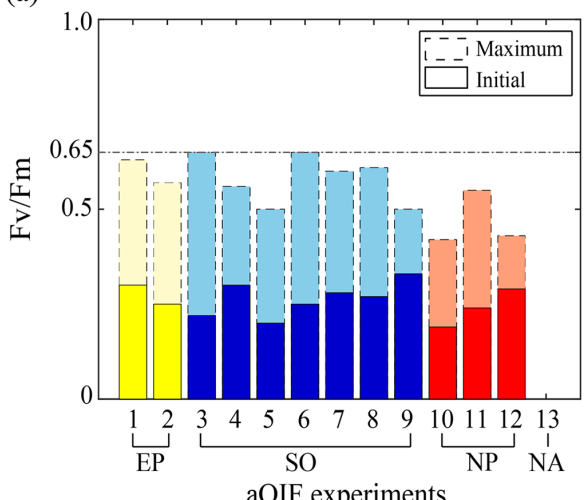

(c)

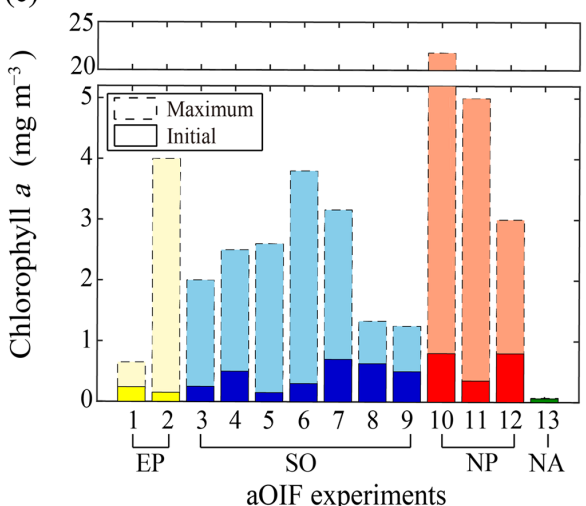

(e)

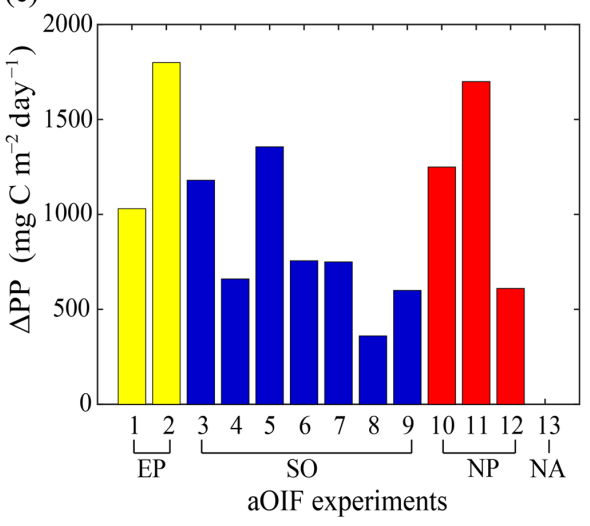

(b)

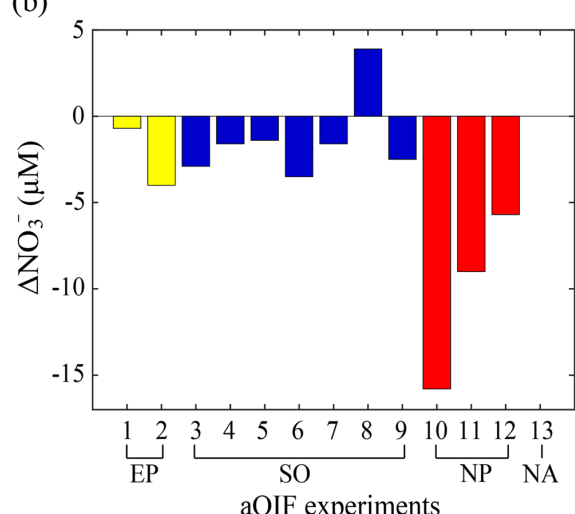

(d)

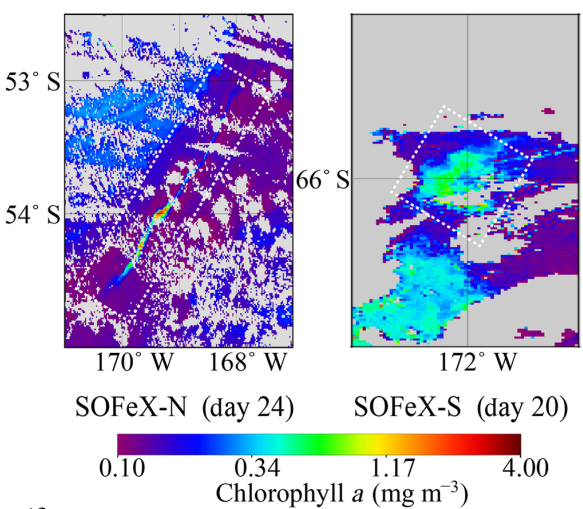

(f)

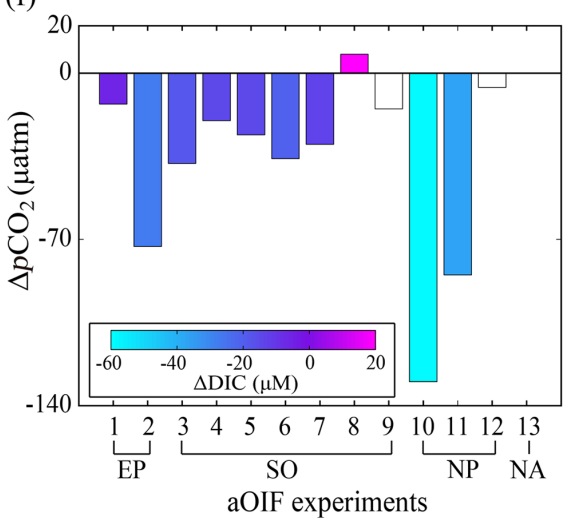

Figure 7. (a) Maximum (bar with dotted line) and initial (bar with solid line) $F_{\mathrm{V}} / F_{\mathrm{m}}$ ratios during artificial ocean iron fertilization (aOIF) experiments. (b) Changes in nitrate concentrations $\left(\Delta \mathrm{NO}_{3}^{-}=\left[\mathrm{NO}_{3}^{-}\right]_{\text {post-fertilization (postf) }}-\left[\mathrm{NO}_{3}^{-}\right]_{\text {pre-fertilization (pref) }}\right.$;M). (c) Maximum (bar with dotted line) and initial (bar with solid line) chlorophyll $a$ concentrations $\left(\mathrm{mg} \mathrm{m}^{-3}\right)$. (d) Distributions of chlorophyll $a$ concentrations $\left(\mathrm{mg} \mathrm{m}^{-3}\right)$ on day 24 after iron addition in the Southern Ocean iron experiment north (SOFeX-N) from MODIS Terra Level-2 daily image and on day 20 in the Southern Ocean iron experiment south (SOFeX-S) from SeaWiFS Level-2 daily image (white dotted box indicates phytoplankton bloom during aOIF experiments). (e) Changes in primary productivity $(\mathrm{PP})\left(\Delta \mathrm{PP}=[\mathrm{PP}]_{\mathrm{postf}}-[\mathrm{PP}]_{\mathrm{pref}} ; \mathrm{mg} \mathrm{Cm}^{-2} \mathrm{day}^{-1}\right)$. (f) Changes in partial pressure of $\mathrm{CO}_{2}\left(p \mathrm{CO}_{2}\right)\left(\Delta p \mathrm{CO}_{2}=\left[p \mathrm{CO}_{2}\right]_{\text {postf }}-\left[p \mathrm{CO}_{2}\right]_{\text {pref }}\right.$; $\mu$ atm). The color bar indicates changes in dissolved inorganic carbon $(\mathrm{DIC})\left(\Delta \mathrm{DIC}=[\mathrm{DIC}]_{\text {postf }}-[\mathrm{DIC}]_{\mathrm{pref}} ; \mu \mathrm{M}\right)$. Note that the $\mathrm{PP}\left(\mathrm{mg} \mathrm{C} \mathrm{m}^{-2} \mathrm{day}^{-1}\right)$ of aOIF experiment number $1($ IronEx-1) was estimated by multiplying the $\mathrm{PP}\left(\mathrm{mg} \mathrm{Cm}^{-3}\right.$ day $\left.{ }^{-1}\right)$ with the mixed layer depth (initial: $30 \mathrm{~m}$ and after: $\left.35 \mathrm{~m}\right)$. The numbers on the $x$ axis indicate the order of aOIF experiments as given in Fig. 4 and Table 1 and are grouped according to ocean basins: equatorial Pacific (EP) (yellow bar), Southern Ocean (SO) (blue bar), subarctic North Pacific (NP) (red bar), and subtropical North Atlantic (NA) (green bar). Sources are Kolber et al. (1994), Martin et al. (1994), Behrenfeld et al. (1996), Coale et al. (1996, 2004), Steinberg et al. (1998), Boyd et al. (2000, 2004, 2005, 2007), Boyd and Law (2001), Frew et al. (2001), Gall et al. (2001b), Boyd (2002), Gervais et al. (2002), Tsuda et al. (2003), Bakker et al. (2005), Bozec et al. (2005), de Baar et al. (2005), Hiscock and Millero (2005), Smetacek et al. (2005, 2012), Takeda and Tsuda (2005), Tsuda et al. (2005, 2007), Wong et al. (2006), Kudo et al. (2009), Tsumune et al. (2009), Harvey et al. (2010), Smetacek and Naqvi (2010), Berg et al. (2011), Currie et al. (2011), Law et al. (2011), Peloquin et al. (2011b), Thiele et al. (2012), Assmy et al. (2013), Martin et al. (2013), Ebersbach et al. (2014), and Latasa et al. (2014). 
Table 5. Initial values of the export flux and the values after fertilization $\left(\mathrm{mg} \mathrm{Cm}^{-2} \mathrm{day}^{-1}\right)$, the corresponding depth inside and outside the fertilized patch for artificial ocean iron fertilization (aOIF) experiments, and measurement method. Values in brackets correspond to the day of measurement after fertilization.

\begin{tabular}{|c|c|c|c|c|c|c|c|}
\hline & Experiment & $\begin{array}{r}\text { In patch } \\
\text { initial (day) }\end{array}$ & $\begin{array}{r}\text { In patch } \\
\text { after (day) }\end{array}$ & $\begin{array}{r}\text { Outside patch } \\
\text { initial (day) }\end{array}$ & $\begin{array}{r}\text { Outside patch } \\
\text { after (day) }\end{array}$ & $\begin{array}{r}\text { Depth } \\
(\mathrm{m})\end{array}$ & Method \\
\hline 1 & IronEx-1 & & & & & & \\
\hline 2 & IronEx-2 & $84(0)$ & $600(7-14)$ & & & 25 & Water-column ${ }^{234} \mathrm{Th}$ \\
\hline \multirow[t]{3}{*}{3} & SOIREE & & $\sim 87$ & & & 100 & Water-column ${ }^{234} \mathrm{Th}$ \\
\hline & & & $185(11-13)$ & $146(0-2)$ & $78(11-13)$ & 110 & Drifting trap \\
\hline & & & $74(11-13)$ & $73(0-2)$ & $38(11-13)$ & 310 & Drifting trap \\
\hline 4 & EisenEx & & & & & & \\
\hline 5 & SOFeX-N & & & & & & \\
\hline \multirow[t]{2}{*}{6} & SOFeX-S & $36(5)$ & $112(27)$ & $48(6)$ & $49(26)$ & 50 & Water-column ${ }^{234} \mathrm{Th}$ \\
\hline & & $19(5)$ & $142(27)$ & $38(6)$ & $56(26)$ & 100 & Water-column ${ }^{234} \mathrm{Th}$ \\
\hline 7 & EIFEX & $\sim 340(0)^{\mathrm{a}}$ & $\sim 1692(32)^{\mathrm{a}}$ & $\sim 396(0)^{\mathrm{a}}$ & $\sim 516(32)^{\mathrm{a}}$ & 100 & Water-column ${ }^{234} \mathrm{Th}$ \\
\hline 8 & SAGE & & & & & & \\
\hline \multirow[t]{3}{*}{9} & LOHAFEX & $\sim 62(0)^{\mathrm{b}}$ & $\sim 94(25)^{\mathrm{b}}$ & $\sim 77(4)^{\mathrm{b}}$ & $\sim 54(34)^{\mathrm{b}}$ & 100 & Water-column ${ }^{234} \mathrm{Th}$ \\
\hline & & $\sim 6(0-2)^{\mathrm{c}}$ & $\sim 5(13-15)^{\mathrm{c}}$ & & $\sim 29(26-27)^{\mathrm{c}}$ & 200 & Neutrally buoyant sediment trap \\
\hline & & & $\sim 12(28-37)^{\mathrm{c}}$ & & $\sim 11(24-29)^{\mathrm{c}}$ & 450 & Neutrally buoyant sediment trap \\
\hline \multirow[t]{4}{*}{10} & SEEDS-1 & $234(1-3)$ & $141(12-14)$ & $148(1-6)$ & $154(10-14)$ & 40 & Drifting trap \\
\hline & & $100(0-2)$ & $423(9-13)$ & & & 50 & Water-column ${ }^{234} \mathrm{Th}^{\mathrm{d}}$ \\
\hline & & $68(1-3)$ & $85(12-14)$ & $61(1-6)$ & $91(10-14)$ & 100 & Drifting trap \\
\hline & & $121(0-2)$ & $460(2-9)$ & & & 200 & Water-column ${ }^{234} \mathrm{Th}$ \\
\hline \multirow[t]{2}{*}{11} & SERIES & $\sim 138(3)^{\mathrm{e}}$ & $480(24)$ & $192(3)$ & $139(15)$ & 50 & Drifting trap \\
\hline & & $\sim 48(3)^{\mathrm{e}}$ & $\sim 192(24)^{\mathrm{e}}$ & & & 100 & Drifting trap \\
\hline \multirow[t]{2}{*}{12} & SEEDS-2 & $290(1-4)$ & $580(19-22)$ & $300(1-8)$ & $509(18-31)$ & 40 & Drifting trap \\
\hline & & $316(1-4)$ & $337(19-22)$ & $213(1-8)$ & $204(18-31)$ & 100 & Drifting trap \\
\hline 13 & FeeP & & & & & & \\
\hline
\end{tabular}

${ }^{a}$ Export flux in EIFEX was digitized from the Supplement Fig. 5.1 of Smetacek et al. (2012). ${ }^{b}$ Export flux in LOHAFEX was digitized from the Fig. 4 of Martin et al. (2013). ${ }^{c}$ Export flux in LOHAFEX was digitized from the Fig. 6 of Martin et al. (2013). ${ }^{\mathrm{d}}$ Export flux in SEEDS-1 was determined from the suspended particles. e Export flux in SERIES was digitized from the Fig. 2 of Boyd et al. (2004).

Sources are Bidigare et al. (1999), Charette and Buesseler (2000), Nodder and Waite (2001), Boyd et al. (2004), Aono et al. (2005), Buesseler et al. (2005), Aramaki et al. (2009), Smetacek et al. (2012), and Martin et al. (2013).

different biogeochemical responses (Tables 3-4 and Fig. 7). In IronEx-1, there were small responses in the $F_{\mathrm{v}} / F_{\mathrm{m}}$ ratio, chlorophyll $a$ concentration, $\mathrm{PP}$, and $\mathrm{pCO}_{2}$ concentrations, but no significant changes in nutrients (Martin et al., 1994). On the other hand, IronEx-2 found dramatic changes in biogeochemical responses, providing support for Martin's hypothesis (Coale et al., 1996). Unexpected small responses during IronEx-1 were due to subduction of the fertilized surface layer by adjacent water (Coale et al., 1998). The contrasting results from the two experiments are also likely to be associated with whether or not there were additional iron injections (IronEx-1: no extra addition; IronEx-2: two additional injections) and different experiment durations (IronEx1: 10 days; IronEx-2: 17 days).

The $F_{\mathrm{V}} / F_{\mathrm{m}}$ ratios provided further detail. In IronEx-1 and IronEx-2, $F_{\mathrm{v}} / F_{\mathrm{m}}$ rapidly increased within $\sim 24 \mathrm{~h}$ of iron addition and reached a maximum of $\sim 0.60$ on the second day (Table 4 and Fig. 7a) (Barber and Hiscock, 2006; Aiken et al., 2008). While the elevated IronEx-1 $F_{\mathrm{v}} / F_{\mathrm{m}}$ ratios promptly disappeared, suggesting rapid iron loss due to the subduction of the fertilized patch and/or adsorption onto colloidal particles (perhaps indicative of insufficient iron supply), increased IronEx-2 $F_{\mathrm{v}} / F_{\mathrm{m}}$ ratios were maintained for 8 days through multiple iron additions, suggesting that additional iron enrichments are likely to be a determining factor in successfully artificially increasing PP through OIF (Kolber et al., 1994; Behrenfeld et al., 1996).

During IronEx-1, chlorophyll $a$ concentrations increased significantly (3-fold), reaching a maximum value of $0.65 \mathrm{mg} \mathrm{m}^{-3}$ in the first 4 days following iron addition (Martin et al., 1994). In IronEx-2, surface chlorophyll $a$ increased nearly 27-fold, with a maximum of $4 \mathrm{mg} \mathrm{m}^{-3}$ after day 7 (Table 4 and Fig. 7c) (Coale et al., 1996). To quantify the changes in carbon fixation following iron addition, the depthintegrated PP (from the surface to the critical depth, euphotic depth, or MLD) was estimated in the iron-fertilized patches. The depth-integrated PP values increased significantly compared to the initial values. The IronEx-2 $\triangle \mathrm{PP}$ (where $\Delta \mathrm{PP}=[\mathrm{PP}]_{\text {post}}-$ fertilization (postf) $-[\mathrm{PP}]_{\text {pre-fertilization }(\text { pref })}$ ) was the highest $\left(\sim 1800 \mathrm{mg} \mathrm{C} \mathrm{m}^{-2}\right.$ day $\left.^{-1}\right)$ of all the aOIF experiments discussed here (Table 4 and Fig. 7e). 
(a)

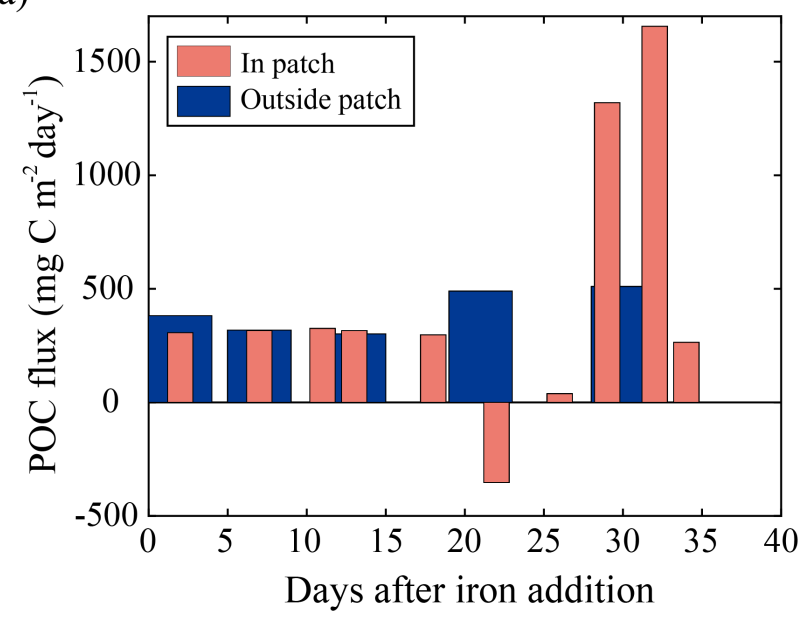

(b)

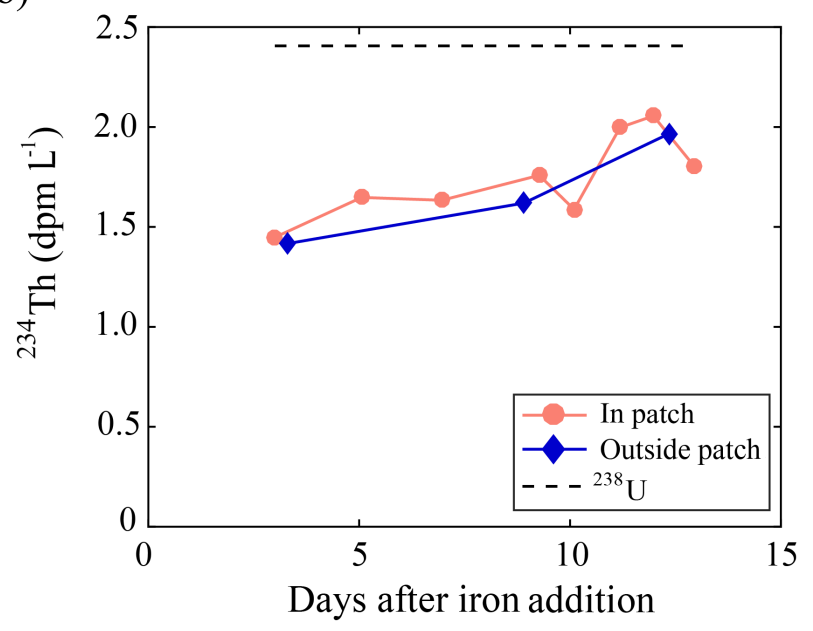

Figure 8. (a) Time series of particulate organic carbon (POC) fluxes estimated from the water-column-based ${ }^{234} \mathrm{Th}$ method $\left(\mathrm{mg} \mathrm{C} \mathrm{m}^{-2} \mathrm{day}^{-1}\right)$ of the upper $100 \mathrm{~m}$ layer inside (red bar) and outside the fertilized patch (blue bar) during the European Iron Fertilization Experiment (EIFEX) (modified from Smetacek et al., 2012). (b) Time series of vertically integrated ${ }^{234} \mathrm{Th}\left(\mathrm{dpm} \mathrm{L}^{-1}\right)$ inside (red circles) and outside the fertilized patch (blue diamonds) relative to the parent uranium-238 ( ${ }^{238} \mathrm{U}$; dpmL ${ }^{-1}$; dotted black line) during the Southern Ocean Iron Release Experiment (SOIREE) (modified from Nodder et al., 2001).

Changes in $p \mathrm{CO}_{2}$ during IronEx-1 were less than expected $\left(\Delta p \mathrm{CO}_{2}=\left[p \mathrm{CO}_{2}\right]_{\text {postf }}-\left[p \mathrm{CO}_{2}\right]_{\text {pref }}=-13 \mu \mathrm{atm}\right)$ (Martin et al., 1994). However, substantial drawdowns of $p \mathrm{CO}_{2}\left(\Delta p \mathrm{CO}_{2}=-73 \mu \mathrm{atm}\right)$ and dissolved inorganic carbon $\left(\Delta \mathrm{DIC}=[\mathrm{DIC}]_{\text {postf }}-[\mathrm{DIC}]_{\text {pref }}=-27 \mu \mathrm{M}\right)$ during IronEx -2 were derived through the increased PP (Table 3 and Fig. 7ef) (Steinberg et al., 1998). As the bloom developed, a significant nitrate uptake (e.g., $\Delta \mathrm{NO}_{3}^{-}=\left[\mathrm{NO}_{3}^{-}\right]_{\text {postf }}-\left[\mathrm{NO}_{3}^{-}\right]_{\text {pref }}=$ $-4.0 \mu \mathrm{M}$ ) was observed (Table 3 and Fig. 7b) and silicate concentrations also gradually decreased from 5.1 to $1.1 \mu \mathrm{M}$ (i.e., limiting diatom growth) over 8 days (Coale et al.,
1996; Boyd, 2002). The depletion of macronutrients in fertilized patches provides indirect evidence that phytoplankton growth in surface waters was driven by aOIF (Boyd and Law, 2001).

Although no phytoplankton community change was observed in IronEx-1, after iron addition in IronEx-2 a shift from a picophytoplankton-dominated community to a microphytoplankton-dominated community was observed, resulting in a diatom-dominated bloom (Behrenfeld et al., 1996; Coale et al., 1996; Cavender-Bares et al., 1999). Diatom biomass increased nearly 70 -fold over 8 days early in the experiment, compared to a less than a 2 -fold increase for the picophytoplankton (Landry et al., 2000). The biomass of mesozooplankton (200-2000 $\mu \mathrm{m})$, such as copepods, grew simultaneously, substantially increasing the community grazing effect of larger animals on phytoplankton standing stocks from $7.8 \% \mathrm{day}^{-1}$ outside the patch to $11.4 \%$ day $^{-1}$ in the patch (Coale et al., 1996). However, grazing did not prevent the development of a diatom bloom over 8 days early in the IronEx-2 experiment (Table 4) (Coale et al., 1996; Rollwagen Bollens and Landry, 2000). The ironinduced diatom bloom began to decline after day $\sim 8$ of the experiment (Landry et al., 2000). The decline was probably associated with the combined effects of both the elevated grazing pressure and the onset of nutrient depletion (i.e., limitation in silicate and/or iron) (Cavender-Bares et al., 1999; Boyd, 2002).

To determine whether the biological pump (i.e., export production) is enhanced after iron addition, the export flux of particulate organic carbon (POC) was estimated using a chemical tracer, the natural radiotracer thorium-234 $\left({ }^{234} \mathrm{Th}\right.$; half-life $=24.1$ days) (Table 5) (Bidigare et al., 1999). The ${ }^{234} \mathrm{Th}$ radionuclide has a strong affinity for particles, and the extent of ${ }^{234} \mathrm{Th}$ removal in the water column is indicative of the export of POC associated with surface PP out of the ML (Buesseler, 1998). IronEx-2 was the first aOIF experiment in which the POC flux from the surface to $25 \mathrm{~m}$ was measured (Table 5). However, no ${ }^{234} \mathrm{Th}$ measurements were made in the unfertilized patch for comparison, and no measurements in the deep ocean were undertaken to demonstrate deep carbon export (Bidigare et al., 1999).

\subsubsection{Southern Ocean}

As in the EP IronEx-1 and 2 experiments, there were initial rapid increases in the $F_{\mathrm{v}} / F_{\mathrm{m}}$ ratio within $24 \mathrm{~h}$ of iron addition in the SO experiments indicating that phytoplankton growth was mainly limited by iron availability. Maximum values of the $F_{\mathrm{v}} / F_{\mathrm{m}}$ ratio ranged from 0.50 (SOFeX-N and LOHAFEX) to 0.65 (SOIREE and SOFeX-S) (Table 4 and Fig. 7a). However, the time taken to reach the maximum $F_{\mathrm{v}} / F_{\mathrm{m}}$ ratio was usually longer than $\sim 10$ days, i.e., much slower than in IronEx-1 and 2 ( $\sim 2$ days) (Boyd and Abraham, 2001; Gervais et al., 2002; Coale et al., 2004; Smetacek et al., 2005; Peloquin et al., 2011b; Martin et al., 2013). The 
slower response time in the SO compared to the EP might be attributed to the colder temperatures $\left(\sim 5\right.$ vs. $\left.\sim 24^{\circ} \mathrm{C}\right)$ and/or the deeper MLDs $(\sim 60$ vs. $\sim 30 \mathrm{~m})$ (Fig. $6 \mathrm{c}$ and d) (Boyd and Abraham, 2001; Boyd, 2002).

The aOIF experiments in the SO recorded $>2$-fold increases in chlorophyll $a$ concentrations compared to initial levels $\left(<0.7 \mathrm{mg} \mathrm{m}^{-3}\right)$, and maximum values between $1.25 \mathrm{mg} \mathrm{m}^{-3}$ (LOHAFEX) and $\sim 3.8 \mathrm{mg} \mathrm{m}^{-3}$ (SOFeX-S) were obtained after artificial iron additions (Table 4 and Fig. 7c). Satellite observations were used to investigate the changing spatial and temporal distribution of chlorophyll $a$ concentration in response to iron fertilization in the fertilized patches compared to the surrounding waters; for example, SOFeX-N and SOFeX-S found elevated chlorophyll $a$ concentrations in fertilized patches after iron addition through satellite images (Fig. 7d) (Boyd et al., 2000; Coale et al., 2004; Westberry et al., 2013).

Following artificial iron enrichment in the SO, $\triangle \mathrm{PP}$ ranged from 360 (SAGE) to $\sim 1356 \mathrm{mg} \mathrm{Cm}^{-2} \mathrm{day}^{-1}$ (SOFeX-N) (Table 4 and Fig. 7e). During SOIREE, EisenEx, SOFeX-N, and SOFeX-S, PP increased continuously throughout the duration of the experiments (Boyd et al., 2000; Gall et al., 2001b; Gervais et al., 2002; Coale et al., 2004; Assmy et al., 2007). However, in EIFEX, SAGE, and LOHAFEX there was a significant increase in PP for $\sim 10$ (SAGE) to 20 (EIFEX) days in response to the iron addition, and decreasing trends after day $\sim 12$ (SAGE) to 25 (EIFEX). The decrease was due to various processes such as export (e.g., EIFEX), lateral dilution with surrounding waters (e.g., SAGE), and high grazing pressure and bacterial respiration (e.g., LOHAFEX) (Boyd, 2002; Gervais et al., 2002; Buesseler et al., 2004; Coale et al., 2004; Peloquin et al., 2011b; Smetacek et al., 2012; Thiele et al., 2012; Assmy et al., 2013; Martin et al., 2013; Latasa et al., 2014).

Using both microscopes and high-performance liquid chromatography pigment analysis, changes in the phytoplankton community affected by iron addition have also been investigated. Most SO aOIF experiments have resulted in blooms of diatoms (Boyd et al., 2007). During SOIREE and EisenEx, the dominant phytoplankton community shifted from pico- and nanophytoplankton (e.g., picoeukaryotes and prymnesiophytes) to microphytoplankton (i.e., diatoms) (Gall et al., 2001b; Gervais et al., 2002; Assmy et al., 2007). In SOFeX-S and EIFEX, diatoms were already the most abundant group prior to iron addition (Coale et al., 2004; Hoffmann et al., 2006; Assmy et al., 2013). The contribution of large diatoms became especially clear in EIFEX where $\sim 97 \%$ of the phytoplankton bloom was attributed to this group (Smetacek et al., 2012; Assmy et al., 2013). However, no taxonomic shift toward diatom-dominated communities ( $<5 \%$ of total phytoplankton community) was observed during SAGE and LOHAFEX, which were conducted under silicate-limited conditions (Harvey et al., 2010; Peloquin et al., 2011b; Martin et al., 2013; Ebersbach et al., 2014). Although SOFeX-N was conducted under low silicate conditions (Fig. 6f), the diatom biomass increased remarkably, making up $\sim 44 \%$ of the total phytoplankton community (Coale et al., 2004). This result was partly influenced by the temporary relief of silicate limitation through lateral mixing of the iron-fertilized waters with surrounding waters, with relatively higher silicate concentrations (Coale et al., 2004).

Iron-mediated increases in $\mathrm{PP}$ resulted in a significant uptake in macronutrients and $p \mathrm{CO}_{2}$ throughout the aOIF experiments in the SO (except for SAGE) (Table 3, Fig. 7b and f). $\Delta \mathrm{NO}_{3}^{-}$ranged from $-3.5 \mu \mathrm{M}$ (e.g., SOFeX-S) to $-1.4 \mu \mathrm{M}$ (e.g., $\mathrm{SOFeX-N}$ ) and $\Delta p \mathrm{CO}_{2}$ ranged from $-38 \mu$ atm (e.g., SOIREE) to $-7.0 \mu$ atm (e.g., LOHAFEX). Although both were initially dominated by diatoms, SOFeX-S had a somewhat greater $\Delta \mathrm{NO}_{3}^{-}(-3.5 \mu \mathrm{M})$ and $\Delta p \mathrm{CO}_{2}(-36 \mu \mathrm{atm})$ than EIFEX $\left(\Delta \mathrm{NO}_{3}^{-}:-1.6 \mu \mathrm{M}\right.$ and $\left.\Delta p \mathrm{CO}_{2}:-30 \mu \mathrm{atm}\right)$ (Coale et al., 2004; Hoffmann et al., 2006; Smetacek et al., 2012; Assmy et al., 2013). However, the smaller silicate uptake $\left(\Delta \mathrm{Si}=[\mathrm{Si}]_{\text {postf }}-[\mathrm{Si}]_{\text {pref }}\right)$ observed during SOFeX$\mathrm{S}(-4.0 \mu \mathrm{M})$ compared to EIFEX $(-11 \mu \mathrm{M})$ was associated with a decrease in silicification (i.e., changes in frustule thickness of the dominant diatom species, Fragilariopsis sp., Twining et al., 2004). During EIFEX, the ratio of heavily silicified diatoms (e.g., Thalassiothrix antarctica) to total diatom biomass increased from 0.24 (day 0) to 0.46 (day 37), leading to the higher Si uptake (Hoffmann et al., 2006; Assmy et al., 2013). Interestingly, the biogeochemical responses in SAGE were totally different from those seen in other experiments as increases in $\Delta \mathrm{NO}_{3}^{-}(+3.9 \mu \mathrm{M}), \Delta p \mathrm{CO}_{2}$ $(+8.0 \mu \mathrm{atm})$, and $\Delta \mathrm{DIC}(+25 \mu \mathrm{M})$ were observed (Table 3 , Fig. $7 \mathrm{~b}$ and $\mathrm{f}$ ). These contrasting results were thought to be the result of entrainment through vertical and horizontal physical mixing into the iron-fertilized patch of surrounding waters with higher nutrient and $p \mathrm{CO}_{2}$ concentrations (Currie et al., 2011; Law et al., 2011).

SOIREE was the first aOIF experiment in the SO to estimate the downward carbon flux into deep waters (Fig. 3c). A comprehensive suite of methods was used: drifting traps, ${ }^{234} \mathrm{Th}$ and the stable carbon isotope of particulate organic matter $\left({ }^{13} \mathrm{C}_{\text {org }}\right)$ estimates derived from high-volume pump sampling, and a beam transmissometer (Nodder and Waite, 2001). However, no measurable change in carbon export was observed in response to iron-stimulated PP (Table 5 and Fig. 8b) (Charette and Buesseler, 2000; Nodder and Waite, 2001; Trull and Armand, 2001; Waite and Nodder, 2001). During EisenEx, an increased downward carbon flux estimated from ${ }^{234} \mathrm{Th}$ deficiency was observed in the ironfertilized patch as the experiment progressed. However, there were no clear differences between in- and outside-patch carbon fluxes (Buesseler et al., 2005). During SOFeX-S, significantly enhanced POC fluxes below the MLD, similar to those observed in natural blooms, were estimated from ${ }^{234} \mathrm{Th}$ measurements after iron enrichment (Buesseler et al., 2005). During SOFeX-N autonomous profilers equipped with transmissometers recorded a downward carbon flux between day 
$\sim 27$ and $\sim 45$ after the first iron addition (Bishop et al., 2004; Coale et al., 2004). However, it was unclear whether surface-fixed carbon was well and truly delivered below the winter MLD. During SAGE and LOHAFEX, which were conducted under silicate-limited conditions (Table 3, Figs. 4c and 6f), no significant enhancement of carbon export was detected (Table 5) (Peloquin et al., 2011b; Martin et al., 2013). This result was likely due to the dominance of picoplankton and grazing that led to rapid recycling of organic matter in the ML. In contrast to the other aOIF experiments, EIFEX, which was conducted within the core of an eddy, showed clear evidence of carbon export well below $500 \mathrm{~m}$, stimulated by artificial iron addition (Jacquet et al., 2008; Smetacek et al., 2012). During EIFEX, the initial export flux, estimated from ${ }^{234} \mathrm{Th}$ in the upper $100 \mathrm{~m}$ of the fertilized patch, was $\sim 340 \mathrm{mg} \mathrm{C} \mathrm{m}^{-2}$ day $^{-1}$ (Table 5 and Fig. 8a) (Smetacek et al., 2012). This value remained constant for about 24 days after iron addition. Between day 28 and 32 a massive increase in carbon export flux (maximum of $\sim 1692 \mathrm{mg} \mathrm{C}^{-2}$ day $^{-1}$ ) was observed in the fertilized patch, while the initial value remained constant in the unfertilized patch (Table 5 and Fig. 8a). The profiling transmissometer with high-resolution coverage confirmed this result, showing an increase in exported POC below $200 \mathrm{~m}$ after day 24 . At least half the ironinduced biomass sank (via the formation of aggregates of diatom species, in particular Chaetoceros dichaeta) to a depth of $1000 \mathrm{~m}$, with a 10 -fold higher sinking rate $\left(500 \mathrm{~m} \mathrm{day}^{-1}\right)$ compared to the initial conditions (Smetacek et al., 2012). Significant changes in export production were not found in any of the other aOIF experiments and, therefore, the impact of artificial iron addition on diatom aggregate formation needs focused study in future aOIF experiments (Boyd et al., 2004; Smetacek et al., 2012; Martin et al., 2013).

\subsubsection{Subarctic North Pacific}

The observed increase in the $F_{\mathrm{v}} / F_{\mathrm{m}}$ ratio in response to aOIF in the subarctic NP suggests that the relief in iron limitation may have assisted phytoplankton growth (Table 4 and Fig. 7a). SEEDS-1 and 2, which were conducted in the western basin, showed continuous increases in the $F_{\mathrm{v}} / F_{\mathrm{m}}$ ratio, with a maximum value of $\sim 0.4$ approximately 10 days after the first iron addition (Tsuda et al., 2003, 2007). During SERIES, which was conducted in the eastern basin, the $F_{\mathrm{v}} / F_{\mathrm{m}}$ ratio rapidly increased within $24 \mathrm{~h}$ of the first iron addition and reached a maximum value of $\sim 0.55$ on day 4 (Boyd et al., 2005). However, the $F_{\mathrm{v}} / F_{\mathrm{m}}$ ratio returned toward the initial value of $<0.3$ as the dissolved iron concentrations decreased to background levels $(<0.2 \mathrm{nM})$ after about day 10 (Tsuda et al., 2003, 2007; Boyd et al., 2005).

Increases in chlorophyll $a$ concentrations were detected in the subarctic NP aOIF experiments in both basins after about the fifth day (Tsuda et al., 2003; Boyd et al., 2004; Suzuki et al., 2009). These increases were especially apparent in SEEDS-1, where they reached a maximum value of $21.8 \mathrm{mg} \mathrm{m}^{-3}$ (27 times the initial value of $0.8 \mathrm{mg} \mathrm{m}^{-3}$ ) (Table 4 and Fig. 7c). This augmentation was the largest among all the aOIF experiments (Tsuda et al., 2003). The dramatic surface chlorophyll $a$ increase observed during SEEDS-1 was partly attributed to the particular range of seawater temperature in the region, which was conducive to diatom growth (i.e., $8-13^{\circ} \mathrm{C}$ ) as well as to the shallower $\operatorname{MLD}(\sim 10 \mathrm{~m})$, which provided a relatively longer surface water residence time for the additional iron (Fig. 6c and d) (Noiri et al., 2005; Takeda and Tsuda, 2005; Tsuda et al., 2005; Tsumune et al., 2005). During SERIES, chlorophyll $a$ concentrations increased substantially from the initial value of 0.35 to $\sim 5 \mathrm{mg} \mathrm{m}^{-3}$ over 17 days, the second highest concentration recorded in all aOIF experiments (Table 4 and Fig. 7c) (Boyd et al., 2004). However, on the 18th day there was a downturn in chlorophyll $a$ as silicate concentrations decreased to $<2 \mu \mathrm{M}$ (Boyd et al., 2005). Although SEEDS-2 was conducted under similar initial conditions to SEEDS-1 (refer to Sect. 2.2.3), there was a minimal increase in chlorophyll $a$ (i.e., maximum value of $3 \mathrm{mg} \mathrm{m}^{-3}$ ) (Fig. 7c). This smaller increase was thought to be the result of strong copepod grazing (SEEDS-2 had almost 5 times more copepod biomass than SEEDS-1) (Table 4) (Tsuda et al., 2007). A similar range was seen in depth-integrated PP, which increased 3-fold or more after iron addition in the subarctic NP aOIF experiments (e.g., from 300-420 to 1000$2000 \mathrm{mg} \mathrm{C} \mathrm{m}^{-2}$ day $^{-1}$ ) (Table 4 and Fig. 7e).

Changes in the composition of phytoplankton groups were investigated in the subarctic NP aOIF experiments. In SEEDS-1 there was a shift from oceanic diatoms (e.g., Pseudo-nitzschia turgidula), with growth rates of $0.5-$ $0.9 \mathrm{day}^{-1}$, to faster-growing neritic diatoms (e.g., Chaetoceros debilis, with a growth rate of $1.8 \mathrm{day}^{-1}$ ) (Tsuda et al., 2005). The effect on the biological pump can be quite different depending on the species of diatom stimulated by the aOIF. Chaetoceros debilis, known to be widespread in coastal environments, intensifies the biological pump by forming resting spores in contrast to grazer-protected, thickly silicified oceanic species (e.g., Fragilariopsis sp. and Thalassiothrix sp.) that contribute silica but little carbon to the sediments. The shift in the dominant phytoplankton species during SEEDS-1 was an important contributor to the recorded increase in phytoplankton biomass. During SERIES, the phytoplankton community changed from Synechococcus and haptophytes to diatoms, and the highest SERIES chlorophyll $a$ concentration (day 17) was associated with a peak in diatom abundance (Boyd et al., 2005). However, during SEEDS-2, no significant iron-induced diatom bloom was observed. Instead, pico- and nanophytoplankton (e.g., Synechococcus, picoeukaryotes, and cryptophytes) ( $>70 \%$ of the total community) dominated throughout the duration of the experiment due to the heavy grazing pressure on diatoms (Table 4) (Tsuda et al., 2007; Sato et al., 2009).

In the subarctic NP experiments, significant changes in macronutrient uptake (i.e., $\Delta \mathrm{NO}_{3}^{-}$and $\Delta \mathrm{Si}$ ), $\Delta \mathrm{DIC}$, and 
$\triangle p \mathrm{CO}_{2}$ in response to aOIF were observed (Table 3 and Fig. $7 \mathrm{~b}$ and f). SEEDS-1, which exhibited the largest increases in chlorophyll $a$ concentrations, also had the largest $\Delta p \mathrm{CO}_{2}(-130 \mu \mathrm{atm})$ and $\Delta \mathrm{DIC}(-58 \mu \mathrm{M})$ (Table 3 and Fig. 7f). These changes led, in turn, to the largest $\Delta \mathrm{NO}_{3}^{-}$ $(-15.8 \mu \mathrm{M})$ (Fig. $7 \mathrm{~b})$ and $\Delta \mathrm{Si}(-26.8 \mu \mathrm{M})$ (Table 3) (Tsuda et al., 2003). The second largest increase in the chlorophyll $a$ concentration was observed in SERIES, where drawdowns of $p \mathrm{CO}_{2}(-85 \mu \mathrm{atm})$, DIC $(-37 \mu \mathrm{M})$, nitrate $(\sim-9.0 \mu \mathrm{M})$, and silicate $(\sim-14.0 \mu \mathrm{M})$ were recorded. During SEEDS2 , the nitrate concentration decreased remarkably from 18.4 to $12.7 \mu \mathrm{M}$ after day 5; however, there was no significant change in silicate concentrations, which would have been expected as a signal of an iron-induced diatom bloom (Tsuda et al., 2007; Suzuki et al., 2009).

Despite the formation of a massive iron-induced phytoplankton bloom during SEEDS-1, there was no large POC export flux during the observation period (Table 5) (Tsuda et al., 2003; Aono et al., 2005; Aramaki et al., 2009). During SERIES and SEEDS-2, which allowed comprehensive time-series measurements of the development and decline of the iron-stimulated bloom, POC fluxes estimated by the drifting traps in the fertilized patch displayed temporal variations (Boyd et al., 2004; Aramaki et al., 2009). The results suggested that, subsequently, the drifting trap captured only a small part of the decrease in ML POC and POC flux losses were mainly governed by bacterial remineralization and mesozooplankton grazing (Boyd et al., 2004; Tsuda et al., 2007).

\subsection{Summary of the significant results from aOIF experiments}

Each aOIF experiment has provided new results on basic processes pertaining to the relationship between pelagic ecology and biogeochemistry, such as selection of the dominant phytoplankton group or species; the effects of grazing; interactions within the plankton community; and effects of nutrient concentrations on the growth of phytoplankton. The aOIF experiments have generally led to changes in the size of the phytoplankton community from pico- and nanophytoplankton to microphytoplankton. This effect was particularly noticeable as diatoms became the dominant species during IronEx-2, SOIREE, EisenEx, SEEDS-1, SOFeX-S, EIFEX, and SERIES. Diatom-dominated blooms induced $>4.5$-fold increases in chlorophyll $a$ concentrations and accounted for $>43 \%$ of the chlorophyll $a$ increase (Cavender-Bares et al., 1999; Boyd et al., 2000; Gall et al., 2001b; Gervais et al., 2002; Coale et al., 2004; Tsuda et al., 2005; Marchetti et al., 2006b; Assmy et al., 2007; Smetacek et al., 2012). The shift to a diatom-dominated community appears to be related to initial availability of silicate (i.e., initial silicate was $>5 \mu \mathrm{M}$ in all the experiments listed above). However, as silicate concentrations decreased to $<2 \mu \mathrm{M}$ due to removal by phytoplankton, diatom blooms rapidly declined. SAGE and
LOHAFEX had low initial levels of silicate $(<2 \mu \mathrm{M})$. As a consequence, pico- and nanophytoplankton dominated their communities and diatom growth was limited by the lack of available silicate. However, during SOFeX-N, initial silicate limitation $(<3 \mu \mathrm{M})$ in the iron-fertilized waters was temporarily relieved through lateral mixing with the surrounding waters that had relatively higher silicate concentrations (Coale et al., 2004), which contributed to a taxonomic shift toward diatom-dominated communities (from $16 \%$ to $44 \%$ of total phytoplankton community). These results suggest that, to develop large-phytoplankton blooms, changeover to a diatom-dominated community after iron addition is needed. A necessary, but not sufficient, condition for such a change to occur is the availability of silicate. Silicate alone is not expected to be sufficient because diatom-dominated blooms were not observed in all experiments with high initial silicate concentrations. IronEx-1 and SEEDS-2 had high initial silicate levels $(>3.9 \mu \mathrm{M})$ considered conducive to the development of a diatom-dominated bloom, but blooms were suppressed due to high grazing pressure. Taken together, the aOIF results suggest that both mesozooplankton grazing rates and initial silicate concentrations play a role in limiting the stimulation of diatom-dominated blooms after artificial iron enrichment.

In experiments with smaller increases $(<3.8$ times) in plankton biomass (IronEx-1, SEEDS-2, SAGE, and LOHAFEX) there was little change in the carbon export flux. Among previous aOIF experiments, the subarctic NP SEEDS-1 experiment, which was conducted under temperature conditions ideal for diatom growth $\left(\sim 8^{\circ} \mathrm{C}\right)$ and with shallow MLDs $(\sim 10 \mathrm{~m})$, produced the greatest changes in surface phytoplankton biomass. However, influence of iron addition on the phytoplankton growth extends from surface to euphotic depth as added iron is mixed within the ML by physical processes (Coale et al., 1998). Although maximum surface chlorophyll $a$ concentration during SEEDS-1 ( $\left.22 \mathrm{mg} \mathrm{m}^{-3}\right)$ was much higher than EIFEX $\left(\sim 3.2 \mathrm{mg} \mathrm{m}^{-3}\right)$, the MLD-integrated chlorophyll $a$ concentrations were similar to $\sim 250 \mathrm{mg} \mathrm{m}^{-2}$ between the two experiments. Therefore, to quantify the exact changes in phytoplankton biomass in response to iron addition, it would be appropriate to consider the MLD-integrated PP for comparison. During IronEx-2, SOIREE, EisenEx, SEEDS-1, SOFeX-N, SOFeX$S$, EIFEX, and SERIES, a $>2$-fold increase in PP within the ML, with massive diatom-dominated blooms, was observed. However, changes in the carbon export varied substantially and differed from experiment to experiment. In SEEDS-1 and SOIREE there was little increase in export flux. These two experiments were conducted over only about 2 weeks. The short duration of these experiments could have prevented the detection of downward carbon export. In SERIES, there was a distinct increase in the POC export flux within the ML $(M L D=30 \mathrm{~m})$, but there was no increase in the carbon export flux below the MLD, and it was reported that the POC produced was rapidly remineralized due to elevated 
heterotrophic bacteria respiration within the ML (Boyd et al., 2004). In SOFeX-S the export flux was enhanced at $100 \mathrm{~m}$, below the MLD (45 m). However, the changes in export flux, after iron addition, were not dramatic compared to natural values (Buesseler et al., 2005). It is possible that the duration of SOFeX-S was also insufficient ( $\sim 4$ weeks) (Table 2 ). EIFEX was the only aOIF experiment that produced significant carbon export to deeper layers (down to $3000 \mathrm{~m}$ ). This high flux was due to aggregate formation with fast sinking rates (Smetacek et al., 2012). EIFEX observed an entire cycle (i.e., development-decline-fate) of the iron-induced phytoplankton bloom during the 39 days of the experiment, which strongly suggests that a sufficient experimental duration is a prerequisite for diatoms to form aggregates and sink (i.e., carbon export). It should also be noted that the rates of bacterial remineralization and grazing pressure on the diatoms were in the same range inside the fertilized patch as outside, which might have assisted the delivery of iron-induced POC from the ML to deep layers (Smetacek et al., 2012). These results suggest that to detect significant carbon exported below the winter MLD following an increase in PP, at least three conditions are necessary: (1) a shift to a diatom-dominated community; (2) low bacterial respiration and grazing pressure rates within the ML; and (3) a sufficient experimental duration, enabling both immediate and delayed responses to iron addition to be observed.

\section{Present: unanswered aOIF questions - export flux, possible side effects, and international law}

OIF has been proposed as a potential technique for rapidly and efficiently reducing atmospheric $\mathrm{CO}_{2}$ levels at a relatively low cost (Buesseler and Boyd, 2003), but there is still much debate. Over the past 25 years, controlled aOIF experiments have shown that substantial increases in phytoplankton biomass can be stimulated in HNLC regions through iron addition, resulting in the drawdown of DIC and macronutrients (de Baar et al., 2005; Boyd et al., 2007; Smetacek et al., 2012; Martin et al., 2013). However, the impact on the net transfer of $\mathrm{CO}_{2}$ from the atmosphere to below the winter MLD through the biological pump (Fig. 3c) is not yet fully understood or quantified and appears to vary with environmental conditions, export flux measurement techniques, and other unknown factors (Smetacek et al., 2012). There have also been a wide range of the estimates of atmospheric $\mathrm{CO}_{2}$ drawdown resulting from large-scale and long-term aOIF based on model simulations (Joos et al., 1991; Peng and Broecker, 1991; Sarmiento and Orr, 1991; Kurz and MaierReimer, 1993; Gnanadesikan et al., 2003; Aumont and Bopp, 2006; Denman, 2008; Jin et al., 2008; Zahariev et al., 2008; Strong et al., 2009; Sarmiento et al., 2010). While it is generally agreed that OIF effectiveness needs to be determined through quantification of export fluxes, there has been no discussion about which export flux measurement techniques are the most effective. Meanwhile, concern has been expressed regarding possible environmental side effects in response to iron addition (Fuhrman and Capone, 1991). These side effects include the production of greenhouse gases (e.g., nitrous oxide, $\mathrm{N}_{2} \mathrm{O}$; and methane, $\mathrm{CH}_{4}$ ) (Lawrence, 2002; Jin and Gruber, 2003; Liss et al., 2005; Law, 2008; Oschlies et al., 2010), the development of hypoxia/anoxia in the water column (Sarmiento and Orr, 1991; Oschlies et al., 2010; Keller et al., 2014), and toxic algal blooms (e.g., Pseudonitzschia) (Silver et al., 2010; Trick et al., 2010). These unwanted side effects could lead to negative climate and ecosystem changes (Fuhrman and Capone, 1991; Sarmiento and Orr, 1991; Jin and Gruber, 2003; Schiermeier, 2003; Oschlies et al., 2010). Model studies suggested that the unintended ecological and biogeochemical consequences in response to large-scale aOIF might cancel out the effectiveness of aOIF. For example, aOIF-enhanced $\mathrm{N}_{2} \mathrm{O}$ production may have offset $\left(>\sim 40 \%\right.$ ) the benefits of $\mathrm{CO}_{2}$ sequestration in the EP (Sarmiento and Orr, 1991; Jin and Gruber, 2003; Oschlies et al., 2010; Hauck et al., 2016). Core unanswered questions remain concerning the different carbon export flux results from different measurement techniques (Nodder and Waite, 2001; Aono et al., 2005), the possible side effects that could directly influence the aOIF effectiveness, and the legal framework that is in place to regulate aOIF operations while simultaneously supporting further studies to increase our understanding of the potential risks and benefits of aOIF (Williamson et al., 2012). With the design of future aOIF experiments in mind, the following section discusses these core questions: (1) which of the methods are optimal for tracking and quantifying carbon export flux, (2) which of the possible side effects have negative impacts on aOIF effectiveness, and (3) what are the international aOIF experimentation laws and can they be ignored?

\subsection{Export flux measurement methods}

A traditional, direct method for estimating POC export fluxes in the water column is a sediment trap that collects sinking particles (Suess, 1980). Sediment traps are generally deployed at specific depths for days to years to produce estimates of total dried mass, POC, particulate inorganic carbon (PIC), particulate organic nitrogen (PON), particulate biogenic silica, $\delta^{13} \mathrm{C}_{\text {org }}$, and ${ }^{234} \mathrm{Th}$. A basic assumption for the use of a sediment trap is that it exclusively collects settling particles, resulting from the gravitational sinking of organic matter produced in surface waters. However, although they are designed to ensure the well-defined collection and conservation of sinking particles, they have accuracy issues due to (1) interference of the hydrodynamic flow across the trap (i.e., strong advective flow), (2) inclusion and/or invasion (accounting for 14\%-90\% of the total POC collected) of metazoan zooplankton (e.g., copepods, amphipods, and euphausiids) capable of vertical migration (Karl and Knauer, 1989; Buesseler, 1991; Buesseler et al., 2007), and (3) loss of 
trapped particles by bacterial decay and/or dissolution during trap deployment and storage periods (Gardner et al., 1983; Knauer et al., 1984; Kähler and Bauerfeind, 2001). The application of sediment traps for the determination of the carbon export flux is relatively more biased in the ML where ocean currents are generally faster and zooplankton are much more active than deep water. These issues suggest that sediment traps alone may not accurately determine carbon export fluxes within the ML.

Even when used at the same depth, traditional sediment traps, such as the surface-tethered drifting trap and bottommoored trap, can greatly over- or underestimate particulate ${ }^{234} \mathrm{Th}$ fluxes compared to water-column-based estimates (Buesseler, 1991). The water-column-based total ${ }^{234} \mathrm{Th}$ deficiency method (the sum of dissolved and particulate activities) is less sensitive than sediment traps to the issues mentioned above and provides better spatial and temporal resolution in flux estimates (Buesseler, 1998). For these reasons, traditional sediment trap POC flux estimates have often been calibrated using the total ${ }^{234} \mathrm{Th}$ deficiency measured using rosette bottle or high-volume pump samples (Coale and Bruland, 1985; Buesseler et al., 2006) as a reference. However, the water-column-based ${ }^{234} \mathrm{Th}$ method is sensitive to the characterization of the POC to ${ }^{234} \mathrm{Th}$ ratio on sinking particles and the choice of ${ }^{234} \mathrm{Th}$ flux models (Buesseler et al., 2006). Therefore, sampling to estimate the POC to ${ }^{234} \mathrm{Th}$ ratio should be conducted below MLD to accurately detect downward carbon export flux into intermediate-deep waters.

Several aOIF experiments have used both sediment traps and ${ }^{234} \mathrm{Th}$ deficiency to estimate the iron-induced POC export flux (Table 5). SOIREE reported distinct differences in POC fluxes estimated from drifting traps $\left(185 \mathrm{mg} \mathrm{m}^{-2} \mathrm{day}^{-1}\right)$ at a $110 \mathrm{~m}$ over day $11-13$ of the experiment and ${ }^{234} \mathrm{Th}\left(\sim 87 \mathrm{mg} \mathrm{m}^{-2}\right.$ day $\left.^{-1}\right)$ at $100 \mathrm{~m}$ (Charette and Buesseler, 2000; Nodder and Waite, 2001). While there was no measurable change in ${ }^{234} \mathrm{Th}$-based POC fluxes during the 13 days of the SOIREE experiment (Fig. 8b), the traps suggested a $27 \%$ increase over the course of the experiment (from 146 to $185 \mathrm{mg} \mathrm{m}^{-2}$ day $^{-1}$ ) (Table 5). It was later discovered that the sediment-trap-based sampling biases caused this supposed increase (Nodder et al., 2001; Nodder and Waite, 2001). Likewise, in SEEDS-1, ${ }^{234} \mathrm{Th}$ based POC fluxes at $50 \mathrm{~m}$ over day 9-13 were estimated to be $423 \mathrm{mg} \mathrm{m}^{-2} \mathrm{day}^{-1}$, but the drifting trap only recorded $141 \mathrm{mg} \mathrm{m}^{-2}$ day $^{-1}$ at $40 \mathrm{~m}$ over day $12-14$, which is 3 times lower (Table 5) (Aono et al., 2005; Aramaki et al., 2009). This large discrepancy between the two methods might be caused by the under-sampling of POC into the drifting traps (Aono et al., 2005).

To resolve the potential biases in traditional sediment traps, a neutrally buoyant (and freely drifting) sediment trap (NBST) was developed (Valdes and Price, 2000; Valdes and Buesseler, 2006). Through preliminary experiments conducted in June and October 1997 at the Bermuda Atlantic Time-series Study site, Buesseler et al. (2000) showed that an NBST system could reduce the horizontal flow and invasion and/or inclusion of zooplankton into the trap samplers and that NBST-based ${ }^{234} \mathrm{Th}$ fluxes were comparable with water-column-based estimates. LOHAFEX has been the only aOIF experiment so far that has measured particle export using PELAGRA (Particle Export measurement using a Lagrangian trap) sediment traps based on the NBST system deployed at two depths of 200 and $450 \mathrm{~m}$ (below the winter MLD) (Martin et al., 2013). However, the PELAGRA sediment traps did not detect aOIF-induced carbon export even though PP did increase within the ML. Water-column-based ${ }^{234} \mathrm{Th}$ measurements estimated the POC flux at $100 \mathrm{~m}$ to be $\sim 94 \mathrm{mg} \mathrm{m}^{-2} \mathrm{day}^{-1}$, whereas the PELAGRA sediment traps estimated the flux at 200 and $450 \mathrm{~m}$ to be $<12 \mathrm{mg} \mathrm{m}^{-2}$ day $^{-1}$ (Table 5) (Martin et al., 2013). It should be noted that both sediment traps and water-column-based ${ }^{234} \mathrm{Th}$ measurements have a limited ability to fully scan the vertical profile of POC fluxes and, therefore, these methods should ideally be complemented with additional techniques that can measure particle stocks at high depth resolution throughout the water column.

To resolve the full column more effectively, LOHAFEX employed an underwater video profiler (UVP), which provided photographic evidence of sinking particles (particle size $\geq 100 \mu \mathrm{m}$ ) from the surface down to $\sim 3000 \mathrm{~m}$, with $\sim 0.2 \mathrm{~m}$ vertical resolution (Smetacek and Naqvi, 2010; Martin et al., 2013). Through an analysis of particle size distributions, the UVP also allowed particles to be classified into fecal pellets, aggregates, and live zooplankton. Total vertical particle volume profiles obtained from the UVP indicated a maximum concentration at $75 \mathrm{~m}\left(\sim 0.3 \mathrm{~mm}^{3} \mathrm{~L}^{-1}\right)$, with a gradual decrease to $150 \mathrm{~m}\left(\sim 0.15 \mathrm{~mm}^{3} \mathrm{~L}^{-1}\right)$. Interestingly, large particles (i.e., zooplankton) were copious between 75 and $100 \mathrm{~m}$, suggesting that there might be high grazing pressure. Heavy grazing might explain the large discrepancy between the $100 \mathrm{~m}$ (water-column-based ${ }^{234} \mathrm{Th}$ method) and 200 and $450 \mathrm{~m}$ (PELAGRA sediment trap) POC flux estimates (i.e., rather than a sampling bias in sediment trap data) (Martin et al., 2013). To continuously monitor vertical changes in POC stocks following iron addition, EIFEX used a transmissometer, providing high vertical resolution $(\sim 24$ data points per meter) and tracking of the iron-induced stocks down to $\sim 3000 \mathrm{~m}$, even though, unlike UVPs, transmissometers do not allow classification of particles (Smetacek et al., 2012). Improving on this method, SOFeX-N applied autonomous carbon explorers equipped with transmissometers, designed to float along with the currents. Three autonomous carbon explorers were deployed, two explored the iron-fertilized patch and one acted as a control outside the patch. Carbon explorers could continuously monitor carbon flux in the field for up to 18 months beyond the initial deployment, which allowed SOFeX-N to observe episodic raining in the iron-fertilized waters (Bishop et al., 2004), indicating a high carbon export flux after artificial iron addition. Furthermore, recent studies also reported that use of optical 
spike signals in particulate backscattering and fluorescence, measured from autonomous platforms such as gliders and floats, can provide high-resolution observations of POC flux (Briggs et al., 2011; Dall'Olmo and Mork, 2014).

The combination of multiple approaches is essential to the successful detection of POC produced in response to iron addition and its fate. NBST systems (e.g., the PELAGRA sediment trap) should be deployed at two depths (i.e., below both the in situ MLD and the winter MLD) to quantify the aOIF-induced POC flux. This technique is improved when accompanied by calibration using water-column-based ${ }^{234} \mathrm{Th}$. Particle profiling systems (e.g., a transmissometer and an UVP) can provide continuous quantitative and qualitative information about sinking particles, with high vertical resolution and full coverage of the water column $(>3000 \mathrm{~m}$ ). They are therefore useful for indirectly identifying deep carbon transport. Autonomous carbon explorers are an excellent alternative, allowing for continuous observation of POC fluxes during and after an aOIF experiment.

\subsection{Considering environmental side effects}

The purpose of aOIF is to reduce the atmospheric $\mathrm{CO}_{2}$ level by stimulating the sequestration of oceanic carbon through artificial iron additions in the HNLC regions, mitigating the global warming threat. Beyond the benefits of aOIF experimentation, scientists have debated the unintended secondary consequences of aOIF, such as production of climate-relevant gases and ocean ecosystem changes. Therefore, it is important to consider the possible negative consequences of aOIF to evaluate whether the aOIF experiments are effective (i.e., net profit: positives $>$ negatives).

To investigate changes in climate-relevant gas emissions produced by biological activities and/or photochemical reactions before and after iron additions, the production of $\mathrm{CH}_{4}$, $\mathrm{N}_{2} \mathrm{O}$, DMS, and halogenated volatile organic compounds (HVOCs) was measured during aOIF experiments (Liss et al., 2005) because their emission may lead to unintended consequences negating the desired effects of aOIF experiments on carbon sequestration. Among the climate-relevant gases, $\mathrm{CH}_{4}$ has a $\sim 20$ times greater warming potential than $\mathrm{CO}_{2}$ (IPCC, 1990). However, $\mathrm{CH}_{4}$ has been considered to be relatively low risk because most of the $\mathrm{CH}_{4}$ formed in the ocean is used as an energy source for microorganisms and is converted to $\mathrm{CO}_{2}$ before reaching the sea surface (Smetacek and Naqvi, 2008; Williamson et al., 2012). The SO nOIF experiment conducted in year 2011 (i.e., Kerguelen Ocean and Plateau compared Study 2: KEOPS-2) (Table 1 and Fig. 4a) showed that $\mathrm{CH}_{4}$ concentrations were 4-fold higher in the naturally iron-fertilized patch than in the control area (Farías et al., 2015). During the SOFeX-N experiment, measurements of dissolved $\mathrm{CH}_{4}$ indicated concentrations were slightly elevated, i.e., by less than $1 \%$ (1.74 ppmv in the fertilized patch and 1.72 ppmv outside the fertilized patch) (Wingenter et al., 2004). Simulated SO large-scale
aOIF has suggested that a $20 \%$ enhancement of $\mathrm{CH}_{4}$ emissions would offset only $<1 \%\left(\sim 4 \mathrm{TgC} \mathrm{yr}^{-1}\right)$ of the resulting carbon sequestration (Oschlies et al., 2010). Hence, additional $\mathrm{CH}_{4}$ production from aOIF experiments is not likely to be significant.

On the other hand, $\mathrm{N}_{2} \mathrm{O}$ has a relatively long lifetime in the atmosphere ( $\sim 110$ years $)$ and has a global warming potential about 300 times greater than $\mathrm{CO}_{2}$ (Forster et al., 2007). The ocean is already a significant source of atmospheric $\mathrm{N}_{2} \mathrm{O}$ (Nevison et al., 2003; Bange, 2006). Oceanic $\mathrm{N}_{2} \mathrm{O}$ is mainly produced by bacterial remineralization. Therefore, increases in $\mathrm{N}_{2} \mathrm{O}$ production after iron additions are expected and, in the long run, contribute to an increase rather than a decrease in the greenhouse effect (Fuhrman and Capone, 1991). During the SOIREE experiment, a significant increase $(\sim 4 \%)$ in mean $\mathrm{N}_{2} \mathrm{O}$ saturation in the pycnocline $(65-80 \mathrm{~m})$ of the fertilized patch $(104.4 \% \pm 2.4 \%)$, as compared to outside the fertilized patch $(100.3 \% \pm 1.7 \%)$, was associated with an increased phytoplankton biomass (Law and Ling, 2001). Measurements of $\mathrm{N}_{2} \mathrm{O}$ saturation during SERIES also showed increases of $8 \%$ at $30-50 \mathrm{~m}$, which were coincident with the accumulation of ammonium and nitrite attributable to increases in bacterial remineralization following increased POC levels (Boyd et al., 2004; Law, 2008). SOIREE-based model estimates suggested that potential $\mathrm{N}_{2} \mathrm{O}$ production at timescales longer than 6 weeks would subsequently offset carbon reduction benefits resulting from the bacterial remineralization of additional carbon fixation by $6 \%-12 \%$ (Law and Ling, 2001). This estimate is in line with the $\mathrm{N}_{2} \mathrm{O}$ offset of $6 \%-18 \%$ suggested by a modeling study (Jin and Gruber, 2003 ) and the 5\%-9\% suggested by a more recent modeling study investigating the effectiveness of long-term and largescale SO aOIF (Oschlies et al., 2010). However, the SO nOIF experiment (i.e., KEOPS-2) suggested that nOIF acts as both a sink and a source for $\mathrm{N}_{2} \mathrm{O}$ (Farías et al., 2015). Excess $\mathrm{N}_{2} \mathrm{O}$ was not found after iron addition in EIFEX, where significant vertical export through the formation of rapidly sinking aggregates was found (Walter et al., 2005; Law, 2008). One explanation for the absence of $\mathrm{N}_{2} \mathrm{O}$ accumulation below the EIFEX patch might be the limited bacterial remineralization due to the rapid export of organic matter well below $500 \mathrm{~m}$ to the seafloor (Law, 2008). Based on the results of previous studies, no consensus has yet been reached on the exact extent of additional $\mathrm{N}_{2} \mathrm{O}$ production after iron additions. However, because there is the potential for excessive $\mathrm{N}_{2} \mathrm{O}$ production that would not only impact the effectiveness of aOIF experiments but also positively contribute to global warming, further studies are required to reach a conclusion.

Unlike $\mathrm{N}_{2} \mathrm{O}$ emissions, which have the potential to offset the effectiveness of aOIF, DMS, a potential precursor of sulfate aerosols that cause cloud formation, may contribute to the homeostasis of the Earth's climate by countering the warming due to increased $\mathrm{CO}_{2}$ emissions (Charlson et al., 1987). DMS is produced by the enzymatic cleavage of planktonic dimethylsulfoniopropionate (DMSP). Microzoo- 
plankton grazing on nanophytoplankton (e.g., haptophytes) is a key factor controlling oceanic DMS production (Dacey and Wakeham, 1986; Gall et al., 2001a; Park et al., 2014). The production of DMS in response to iron addition was measured during all aOIF experiments. In the EP and SO, DMS production increased, but, in the subarctic NP, it remained constant or decreased (Boyd et al., 2007; Law, 2008). There were significant short-term increases in DMS production in IronEx-2 (from 2.5 to $4.2 \mathrm{nM}$ ), SOIREE (from 0.5 to $3.4 \mathrm{nM}$ ), EisenEx (from 1.9 to $3.1 \mathrm{nM}$ ), and SOFeX-N ( $7.7 \mathrm{nM}$ in the fertilized patch and $1.6 \mathrm{nM}$ outside the fertilized patch) (Turner et al., 1996, 2004; Wingenter et al., 2004, 2007; Liss et al., 2005). The maximum DMS production observed was a 6.8 -fold increase after iron addition in SOIREE (Turner et al., 2004). During the SOIREE experiment, the initial dominant phytoplankton species were haptophytes and they remained dominant until day 7 . Since then, DMS production was increased by microzooplankton grazing on DMSP-rich haptophyte groups (e.g., Phaeocystis) (Gall et al., 2001a). Similarly, a 4.8-fold enhancement of DMS production was observed in SOFeX-N. Estimates derived by the extrapolation of SOFeX-N DMS production results suggested that fertilizing $\sim 2 \%$ of the SO area over the course of a week would result in a $20 \%$ increase in the total SO DMS flux, which would lead to a $2{ }^{\circ} \mathrm{C}$ decrease in air temperature over the SO (Wingenter et al., 2007). On the other hand, the SO nOIF experiment (KEOPS-1) conducted in year 2005 (Table 1 and Fig. 4a) showed that DMS production was not markedly higher in the naturally fertilized area compared to the surrounding waters (Belviso et al., 2008). In addition, a 20 -year aOIF simulation through a three-dimensional ocean biogeochemical model did not show significant increase in DMS emissions from the SO (Bopp et al., 2008). Interestingly, there were no significant changes in DMS production after iron additions in the western subarctic NP SEEDS- 1 and 2 experiments, despite increases in PP (Takeda and Tsuda, 2005; Nagao et al., 2009). Furthermore, in the eastern subarctic NP, SERIES DMS production increased from $8.5-10.9 \mathrm{nM}$ on day 1 to a maximum of $41.2 \mathrm{nM}$ on day 10 , but decreased to $<0.03 \mathrm{nM}$ by the end of the experiment due to an increase in bacterial abundance (Table 4) (Levasseur et al., 2006). It is therefore difficult to predict the iron-induced DMS response, because OIF itself is not the only source of DMS. Based on the results of previous aOIF experiments, DMS production was sensitive in the EP and SO, but was less sensitive in the subarctic NP (Law, 2008). These results indicate that further process and modeling studies for each region are required to determine the production and degradation of DMS, both following iron fertilization and in the natural environment.

HVOCs, such as $\mathrm{CH}_{3} \mathrm{Cl}, \mathrm{CH}_{3} \mathrm{Br}$, and $\mathrm{CH}_{3} \mathrm{I}$, are well known for their ability to destroy ozone in the lower stratosphere and marine boundary layer (Solomon et al., 1994) and were also measured during past aOIF experiments (Wingenter et al., 2004; Liss et al., 2005). However, no consis- tent results have been reported for HVOCs production (Liss et al., 2005). In SOFeX-N, the impact of iron addition on HVOCs was complicated, with $\mathrm{CH}_{3} \mathrm{Cl}$ concentrations remaining unchanged and $\mathrm{CH}_{3} \mathrm{Br}$ concentrations increasing by $14 \%$ (6.5 pptv in the fertilized patch and $5.7 \mathrm{pptv}$ outside the fertilized patch), while $\mathrm{CH}_{3} \mathrm{I}$ concentrations decreased by $23 \%$ ( $4.9 \mathrm{pptv}$ in fertilized patch and $6.4 \mathrm{pptv}$ outside the fertilized patch) (Wingenter et al., 2004). In contrast, $\mathrm{CH}_{3} \mathrm{I}$ concentrations increased $\sim 2$-fold during EisenEx (Liss et al., 2005). Such a complicated response suggests that, as for DMS, further study is needed to fully understand natural cycling of HVOCs and their responses to aOIF.

Another important consideration is the extent to which the effectiveness of aOIF is canceled out by its tendency to lead to ocean ecosystem changes such as a decrease in dissolved oxygen and an increase in domoic acid (DA) levels. The decomposition of iron-addition-enhanced biomass may cause decreased oxygen concentrations in subsurface waters, but midwater oxygen depletion has not been reported from aOIF experiments to date (Williamson et al., 2012). Early modeling studies suggest that anoxic conditions may develop after long-term, large-scale aOIF (Fuhrman and Capone, 1991; Sarmiento and Orr, 1991), whereas a recent study based on more sophisticated models showed sustained well-oxygenated conditions $\left(\mathrm{O}_{2} \approx 120 \mu \mathrm{M}\right)$ even under simulated aOIF south of $30^{\circ} \mathrm{S}$ on a 100-year timescale from 2010 to 2110 (Oschlies et al., 2010). Keller et al. (2014) found that simulated SO large-scale aOIF south of $40^{\circ} \mathrm{S}$ from the year 2020 to 2100 under a high- $\mathrm{CO}_{2}$-emissions scenario (Meinshausen et al., 2011) may develop suboxia $\left(\mathrm{O}_{2}<10 \mu \mathrm{M}\right)$ in the year 2125 . Clearly, the circumstances under which a substantial decline in oxygen inventory can be caused by large-scale aOIF need further study.

The changes in phytoplankton community composition after iron addition discussed in Sect. 2.4 may also have unintended consequences. For example, such changes could lead to potentially toxic species dominating plankton assemblages (Silver et al., 2010; Trick et al., 2010). Some aOIF experiments (e.g., IronEx-2, SOIREE, EisenEx, SOFeX-N, SOFeX-S, and SERIES) generated large blooms dominated by pennate diatoms belonging to the genus Pseudo-nitzschia (de Baar et al., 2005; Silver et al., 2010; Trick et al., 2010). Some Pseudo-nitzschia species have the capacity to produce the neurotoxin DA that can detrimentally affect marine ecosystems. However, no DA was found during EisenEx and SERIES, even though Pseudo-nitzschia were dominant (Gervais et al., 2002; Assmy et al., 2007; Marchetti et al., 2008). However, phytoplankton samples used to estimate DA production have sometimes been stored for a long time before the analysis, for example, 12 years in IronEx-2 and 4 years in SOFeX-S (Silver et al., 2010). Trick et al. (2010) argued that storage might have affected the DA content in the samples, which led to an underestimation in DA concentrations. Nevertheless, discernable changes in DA production were found in IronEx-2 and SOFeX-S experiments (Silver et al., 
2010). It is likely that detection was possible because these samples were collected with net tows (20 to $30 \mu \mathrm{m}$ mesh phytoplankton nets), which provided concentrated samples of larger phytoplankton including Pseudo-nitzschia (e.g., Pseudo-nitzschia abundance: $1.3 \times 10^{6}$ cells L $^{-1}$ in IronEx-2 and $7.5 \times 10^{4}$ cells L $^{-1}$ in SOFeX-S). During IronEx-2 and SOFeX-S, high cell abundances of Pseudo-nitzschia $\left(10^{6}\right.$ and $10^{5}$ cells $\mathrm{L}^{-1}$, respectively) combined with moderate DA cell quotas ( 0.05 and $1 \mathrm{pgDA}$ cell $^{-1}$, respectively) produced toxin levels as high as 45 and $220 \mathrm{ngAL}^{-1}$ in the water, respectively, i.e., toxin levels high enough to damage marine communities in coastal waters (Scholin et al., 2000; Schnetzer et al., 2007). Trick et al. (2010) suggested that largescale OIF may induce DA accumulation with developing toxic Pseudo-nitzschia blooms. However, large uncertainties remain as Trick et al. (2010) simply extrapolated DA concentration based on bottle incubation experiments with HNLC surface waters to the DA production expected from largescale OIF. As a result, it is necessary to clarify and quantify DA production in response to aOIF, with concentrated larger phytoplankton samples collected using net tows (20 to $30 \mu \mathrm{m}$ mesh phytoplankton nets). Here again, existing research indicates that the processes involved need to be better understood in the natural environment before the ramifications of aOIF can be fully understood.

Whether aOIF is a viable carbon removal strategy is still under debate (Boyd et al., 2007; Smetacek and Naqvi, 2008). The production of climate-relevant gases such as $\mathrm{N}_{2} \mathrm{O}$, DMS, and HVOCs, which is influenced by the remineralization of sinking particles that follows OIF-induced blooms; the decline in oxygen inventory; and the production of DA are particularly important to understand. These processes can directly and indirectly modify the effectiveness of carbon sequestration, with either positive or negative effects. Therefore, monitoring declines in oxygen content and production of climate-relevant gases and DA to evaluate the effectiveness of aOIF as a geoengineering approach is essential. The processes discussed here represent the current state of knowledge concerning aOIF side effects. The direct and indirect environmental consequences remain largely unresolved due to the inconsistent and highly uncertain outcomes of the experiments conducted so far, as well as our poor understanding of the processes involved under both nOIF and aOIF conditions (Chisholm et al., 2001; Johnson and Karl, 2002; Williamson et al., 2012). However, considering the increasing evidence for the necessity to keep warming at or below $1.5^{\circ} \mathrm{C}$ (Rogelj et al., 2015), there continues to be a need to quantitatively determine the effectiveness of aOIF as a longterm means for reducing atmospheric $\mathrm{CO}_{2}$ through the quantification of aOIF side effects.

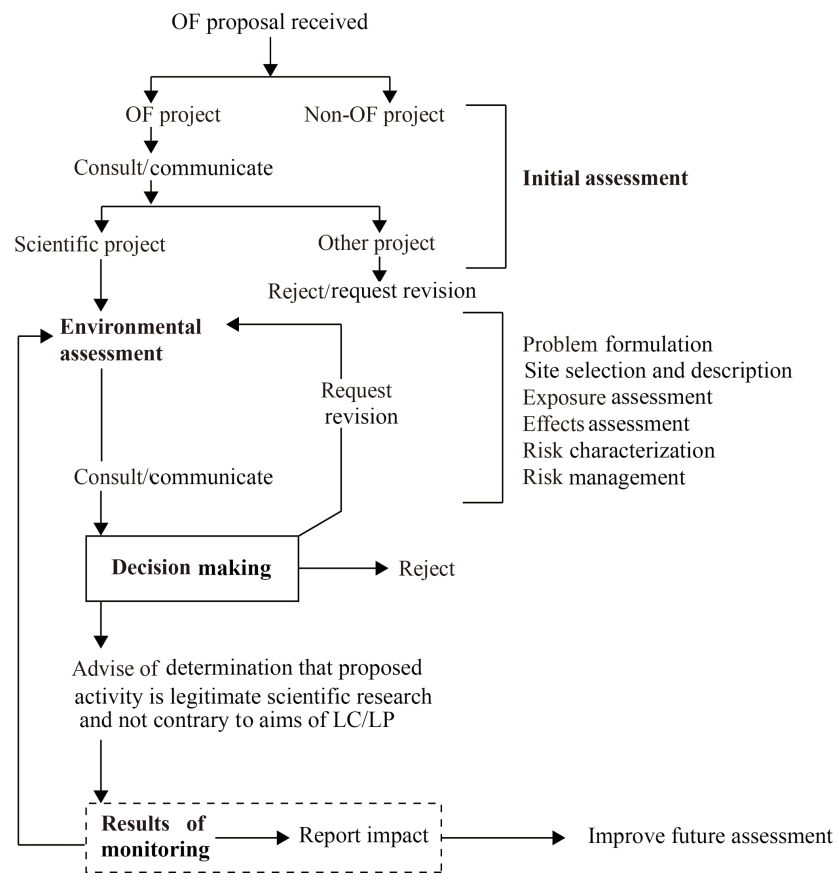

Figure 9. Assessment framework for scientific research involving ocean fertilization (OF) (modified from Resolution LC-LP.2, 2010).

\subsection{Regulation of aOIF: international law of the sea as it applies to aOIF}

To prevent pollution of the sea from human activities, the international Convention on the Prevention of Marine Pollution by Dumping of Wastes and Other Matter (London Convention, 1972) was amended in 1972. In 1996, contracting parties to the London Convention adopted the Protocol to the London Convention (London Protocol, 1996). This places legal restrictions on the dumping of wastes and other matter that may cause hazard, harm, and damage in the ocean and/or interfere with the marine environment. However, the London Convention and Protocol (LC/LP) did not establish specific laws to protect the ocean environment against the side effects of fertilization activities. In 2007, several commercial companies (e.g., GreenSea Venture, http://www. greenseaventure.com, last access: 6 September 2018; and Climos, http://www.climos.com, last access: 6 September 2018) promoted large-scale $\left(10000 \mathrm{~km}^{2}\right)$ commercial aOIF as a climate mitigation strategy and as a means to gain carbon credits (Chisholm et al., 2001; Buesseler and Boyd, 2003; Freestone and Rayfuse, 2008). Meanwhile, assessments of the effectiveness of aOIF have been limited to small fertilized patches $\left(25-300 \mathrm{~km}^{2}\right)$ (Table 1 and Fig. 6a) due to the time and expense of comparing fertilized and unfertilized areas (ACE CRC, 2008). As discussed earlier, these small-scale experiments have left many unanswered scientific questions regarding both the effectiveness and the potential impacts of aOIF (Lawrence, 2002; Buesseler and Boyd, 2003). In the 
same year, noting the potential risks and benefits, the LC/LP scientific group released a statement on large-scale ocean fertilization and recommended that ocean fertilization activities be evaluated carefully to ensure that such operations were not contrary to the aims of the LC/LP.

At the 2008 LC/LP meeting, the contracting parties adopted Resolution LC-LP.1 (2008) on the regulation of ocean fertilization. This resolution prohibited ocean fertilization activities until such time that specific guidance could be developed to justify legitimate scientific research. There was an exception for "small-scale scientific research studies within coastal waters" to permit the development of proposals that would lead to an assessment framework for scientific ocean fertilization research (Resolution LC-LP.1, 2008). In the meantime, there was a call to develop an assessment framework for ocean fertilization experiments to assess, accurately, scientific research proposals (Resolution LC-LP.1, 2008). In 2010, LC/LP parties developed Resolution LCLP.2 (2010), adopting an Assessment Framework for Scientific Research Involving Ocean Fertilization to be used to assess, on a case-by-case basis, whether any proposed ocean fertilization activity constitutes legitimate scientific research falling within the aims and scope of Resolution LC-LP.1 (2008) (Fig. 9) (Resolution LC-LP.2, 2010). This framework demands preliminary scientific research prior to any aOIF experimentation. There must be a transparent/reasonable scientific rationale/purpose to the experiment and a risk analysis must be undertaken using parameters such as problem formulation, site selection, exposure and effect assessment, and risk characterization and management. Monitoring is also required as an integral component of all approved (i.e., legitimate) scientific aOIF research activity to assess ecological impacts and to review actual vs. intended geoengineering benefits (ACE CRC, 2015). The process of acquiring permission for an aOIF experiment from the LC/LP is a multifaceted enterprise involving not only ecology, biogeochemistry, and climate science (i.e., Martin's iron hypothesis), but also social sciences (i.e., ethics and efficacy of climate-engineering measures) and ocean governance (i.e., international law of the sea and its enforcement). In October 2013, the LC/LP parties adopted amendments that categorize aOIF as marine geoengineering, thereby prohibiting operational aOIF activities, but enabling aOIF scientific research that meets the permit conditions through the environmental assessment framework (Resolution LP.4 (8), 2013). This means that large-scale (i.e., $>300 \mathrm{~km}^{2}$ based on previous aOIF experiments; exact areal sizes are not determined in the LC/LP) and/or commercial aOIF (e.g., the 2012 Haida Gwaii Iron Dump off the west coast of Canada) are currently banned by international regulations. Under LC/LP, commercial aOIF efforts cannot proceed because of the large uncertainties related to large-scale aOIF.

\section{Future: designing future aOIF experiments}

Scientific aOIF research has focused on improving our understanding of the effectiveness, capacity, and risks of OIF as an atmospheric $\mathrm{CO}_{2}$ removal strategy both in the future and the past (in particular glacial periods). Although the first aOIF experiments took place more than 20 years ago, the legal and economic aspects of such a strategy in terms of the international laws of the sea and carbon offset markets are not yet clear (ACE CRC, 2015). Nonetheless, previous small-scale aOIF experiments have demonstrated a considerable potential for easily and effectively reducing atmospheric $\mathrm{CO}_{2}$ levels. Accordingly, physical-biogeochemicalecological models and nOIF experiments (long-term) have been conducted in an effort to overcome some of the limitations of short-term aOIF experiments (e.g., spatial and temporal scales) and to predict the effectiveness of long-term and large-scale fertilization (Aumont and Bopp, 2006; Blain et al., 2007; Denman, 2008; Pollard et al., 2009; Sarmiento et al., 2010). For example, earlier global biogeochemical models have indicated that massive fertilization could draw down atmospheric $\mathrm{CO}_{2}$ by as much as $107 \mu$ atm in 100 years (Joos et al., 1991; Peng and Broecker, 1991; Sarmiento and Orr, 1991; Kurz and Maier-Reimer, 1993). Recent global models, with more realistic ecosystem and biogeochemical cycles, predict values closer to a $33 \mu \mathrm{atm}$ drawdown in atmospheric $\mathrm{CO}_{2}$ (Aumont and Bopp, 2006). These results suggest that the amount of carbon sequestration resulting from aOIF represents only a modest offset, i.e., a contribution of $\sim 10 \%$ over the range of IPCC future emission scenarios (IPCC, 2000; Aumont and Bopp, 2006; Denman, 2008; Zahariev et al., 2008). The nOIF experiments have also produced much higher carbon sequestration rates than the smallscale aOIF experiments (Morris and Charette, 2013). Furthermore, the results from nOIF experiments do not support the potential negative impacts proposed for OIF experiments, even at larger scales (Belviso et al., 2008). However, these nOIF results do not guarantee that aOIF as a geoengineering approach is able to achieve the high effectiveness associated with carbon sequestration and enables a simple scaling up as a prediction tool, because the nOIF experiments differ from the aOIF experiments in the mode of iron supply. In particular, nOIF is a continuous and slow process and its iron source is based on the upwelling of iron-rich subsurface waters to the surface layer, whereas aOIF is intended to be episodic, with massive short-term iron additions (Blain et al., 2007). In addition, in nOIF it is difficult to accurately identify iron sources due to the complexity of the system, whereas in aOIF there is quantitative and qualitative information about iron additions and sources (Blain et al., 2008). Contrary to the results of aOIF experiments in the SO (e.g., SOIREE and

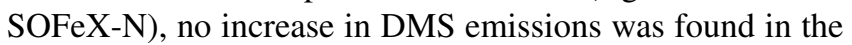
SO nOIF experiment (i.e., KEOPS-1) (Belviso et al., 2008), suggesting that it might be difficult to identify the potential long-term negative effects of aOIF through the study of nat- 
urally fertilized systems, at least in the SO. There is also a broad swath of hypotheses in the fields of pelagic ecologybiogeochemistry that can be tested with OIF experiments using the correlations between temperature, $\mathrm{CO}_{2}$ concentrations, and dust over the past four glacial-interglacial cycles on the one hand and bottle experiments showing iron limitation of phytoplankton growth in HNLC regions on the other. Therefore, it is important to continue undertaking small-scale studies to obtain a better understanding of natural processes in the $\mathrm{SO}$ as well as to assess the associated risks and so lay the groundwork for evaluating the potential effectiveness and impacts of large-scale aOIF as a geoengineering solution to anthropogenic climate change. It is therefore of paramount importance that future aOIF experiments continue to focus on the effectiveness and capacity of aOIF as a means of reducing atmospheric $\mathrm{CO}_{2}$, but they should also carefully consider the location (i.e., where), timing (i.e., when), and duration (i.e., how long), as well as modes of iron addition (i.e., how), tracing methods and measurement parameters (i.e., what), and side effects on marine/ocean ecosystems (i.e., what concerns). They should build on the results of previous aOIF experiments to develop our understanding of the magnitude and sources of uncertainties and provide confidence in our ability to reproduce results.

Where. The first consideration for a successful aOIF experiment is the location. The dominance of diatoms in phytoplankton communities plays a major role in increasing the biological pump because diatom species can sink rapidly as aggregates or by forming resting spores to efficiently bypass the intense grazing pressure of mesozooplankton (e.g., copepods, salps, and krill) and export carbon out of the winter ML (Tréguer et al., 1995; Salter et al., 2007; Assmy et al., 2013; Rembauville et al., 2015, 2016). Previous aOIF experiments have shown that silicate concentration and mesozooplankton stocks (i.e., copepods) are the crucial factors controlling diatom blooms (Boyd et al., 2000; Gervais et al., 2002; Coale et al., 2004; Tsuda et al., 2007; Smetacek et al., 2012). Therefore, to obtain the greatest possible carbon export flux in response to iron addition, aOIF experiments should be designed in regions with high silicate concentrations and low grazing pressure. It will be important to conduct initial surveys to measure the degree of grazing pressure in HNLC regions with high silicate concentrations such as in the subarctic NP (e.g., SEEDS-1 experiment) and the south of the SO PF (e.g., SOFeX-S experiment) $>15 \mu \mathrm{M}$ (Fig. 4c). In selecting sites for aOIF, it is also important to distinguish the iron-fertilized patch from the surrounding unfertilized waters to easily and efficiently observe iron-induced changes (Coale et al., 1996). Ocean eddies provide an excellent setting for aOIF experimentation because they tend to naturally isolate interior waters from the surrounding waters. Mesoscale eddies range from 25 to $250 \mathrm{~km}$ in diameter and maintain their characteristics for 10-100 days after formation (Morrow and Le Traon, 2012; Faghmous et al., 2015). Eddy centers tend to be subject to relatively slow current speeds, with low shear and high vertical coherence, providing ideal conditions for tracing the same water from the surface to below the winter MLD, while simultaneously minimizing lateral stirring and advection (Smetacek et al., 2012). Finding an appropriate eddy setting in a study area should be a high priority consideration when designing an aOIF experiment (Smetacek and Naqvi, 2008). Mesoscale eddies can be reliably identified and tracked with satellite sea surface height anomalies (Smetacek et al., 2012).

When. The second consideration for a successful aOIF experiment is timing, which includes when an experiment starts. PP in ocean environment is generally limited by nutrient availability and/or by light availability, often referred to as a single or co-limitation. PP in the SO, a representative HNLC region, is subject to co-limitation by micro- or macronutrients (i.e., iron and/or silicate) and light availability (Mitchell et al., 1991). To the south of the SO PF, phytoplankton blooms usually occur during early summer (i.e., from late December to early January) due to an increase in the nutrient flux from subsurface waters induced by winter mixing, along with the favorable light conditions provided by a shoaling of the ML (Moore and Abbott, 2002). Weekly and monthly climatological maps of chlorophyll $a$ concentrations derived from satellite data could provide the necessary information for determining the timing of blooms in the SO PF (Westberry et al., 2013). Prior to December, phytoplankton growth is mainly limited due to light availability (Mitchell et al., 1991; Veth et al., 1997; Abbott et al., 2000), while after January (i.e., during late summer and early autumn from February to March) it is mainly limited due to iron and silicate availability (Abbott et al., 2000; Mengelt et al., 2001; Nelson et al., 2001). In previous SO aOIF experiments conducted between spring and early autumn, PP was mainly limited by iron and/or silicate availability rather than light availability (except when heavy clouds led to severe light limitation, which only occurred for a few days during EisenEx) (Gervais et al., 2002; Bakker et al., 2005; Smetacek and Naqvi, 2008; Peloquin et al., 2011a). The grazing pressure of mesozooplankton on large diatoms was also a major limiting factor in diatom production (Schultes et al., 2006; Smetacek and Naqvi, 2010) and was generally higher during late summer and early autumn (February to March) (Hunt and Hosie, 2006; Rembauville et al., 2015). Considering the key factors (i.e., micro- or macronutrient availability, light availability, and grazing pressure) controlling PP in the SO, the most appropriate timing for the start of an aOIF experiment to the south of the SO PF is likely to be the early summertime (i.e., late December to early January).

How long. The third consideration for a successful aOIF experiment is the duration. The periods in which phytoplankton blooms have been maintained by aOIF have lasted from $\sim 10$ to $\sim 40$ days (Kolber et al., 1994; Martin et al., 1994; Coale et al., 1996, 2004; Boyd et al., 2000, 2004; Tsuda et al., 2005; Smetacek et al., 2012). Although the first 2 weeks have a decisive effect on the development and demise of 
(a)

(b)
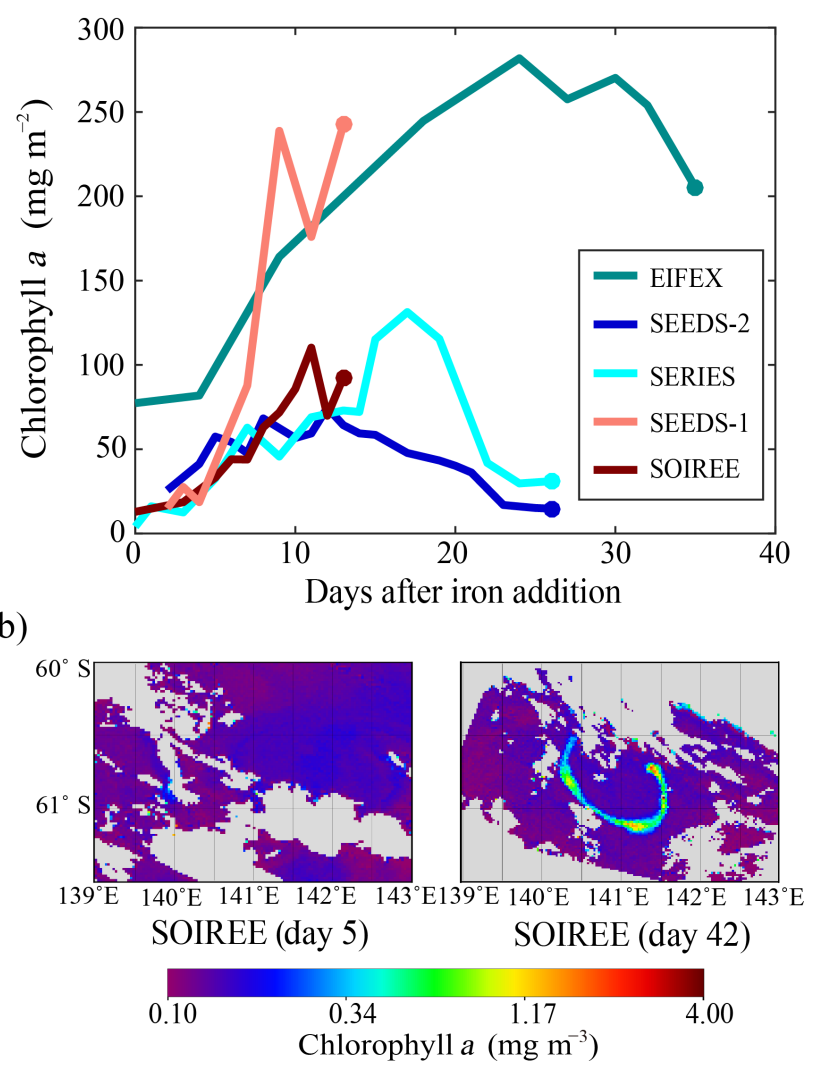

Figure 10. (a) Time series of mixed-layer-depth-integrated chlorophyll $a$ concentrations $\left(\mathrm{mg} \mathrm{m}^{-2}\right)$ during the Southern Ocean Iron Release Experiment (SOIREE) (brown line), Subarctic Pacific iron Experiment for Ecosystem Dynamics Study 1 (SEEDS-1) (coral line), Subarctic Ecosystem Response to Iron Enrichment Study (SERIES) (cyan line), SEEDS-2 (blue line), and European Iron Fertilization Experiment (EIFEX) (teal line). (b) The distributions of chlorophyll $a$ concentrations $\left(\mathrm{mg} \mathrm{m}^{-3}\right)$ on day 5 and day 42 during SOIREE from SeaWiFS Level-2 daily images. Sources are Gall et al. (2001a), Tsuda et al. (2007), and Assmy et al. (2013).

the bloom, it has been suggested that most aOIF experiments did not cover the full response times from onset to termination (Boyd et al., 2005). For example, SOIREE and SEEDS-1 had relatively short observation periods (13 days) and saw increasing trends in PP throughout the experiments (Fig. 10a), suggesting that the observation period should have been extended. Furthermore, after the end of SOIREE, ocean-color satellite images showed continued high chlorophyll $a$ concentrations $\left(>1 \mathrm{mg} \mathrm{m}^{-3}\right)$ in the iron-fertilized patch, which was visible as a long ribbon shape that extended some $150 \mathrm{~km}$ for $>40$ days ( $\sim 6$ weeks) after the first iron addition (Fig. 10b) (Abraham et al., 2000; Westberry et al., 2013). This indicates that short experimental durations may not be sufficient for detecting the full influence of aOIF on PP and the ecosystem (Figs. 8b and 10), although some useful information can be gleaned over short periods, including dominance of spore-forming Chaetoceros species during the SEEDS-1 experiment (Boyd et al., 2000; Tsuda et al., 2003, 2005; de Baar et al., 2005). SOFeX-S also resulted in relatively low export production despite the high PP due to the experimental duration being insufficient to cover the termination of the phytoplankton bloom. However, SERIES, SEEDS-2, EIFEX, and LOHAFEX did fully monitor all phases of the phytoplankton bloom from onset to termination. EIFEX, the third-longest aOIF experiment, at 39 days, was the only one that observed iron-induced deep export production between day 28 and 32 (Table 5 and Fig. 8a) (Smetacek et al., 2012; Assmy et al., 2013). Furthermore, long-term observations covering the later stage of bloom development during nOIF experiments resulted in much higher $\mathrm{C}: \mathrm{Fe}$ export efficiencies compared to the short-term aOIF (Blain et al., 2007; Pollard et al., 2009). Based on previous aOIF experiments, it would, therefore, be important to detect the full phase of a phytoplankton bloom to determine accurately the amount of iron-induced POC exported out of the winter ML. The observation period is, therefore, an important consideration with regard to budget and effectiveness estimates. It is suggested that the experimental duration should be a minimum of $\sim 40$ days based on the SOIREE experiment, which produced the longest iron-induced bloom (> 40 days). In addition, autonomous observation platforms are essential to monitor post-assessment of effectiveness, capacity, and risks of aOIF for at least 12 months after experiment termination.

How. The fourth consideration for a successful aOIF experiment lies in the strategy/approach of adding and maintaining dissolved iron within the ML to produce a phytoplankton bloom. First, the chemical form for iron addition should be acidified iron sulfate, which is less expensive and more bioavailable than other iron compounds. The amount of iron sulfate required is calculated according to the target concentration of the dissolved iron and volume (MLD $\times$ patch size). Based on bottle incubation experiments, target iron concentrations of $\sim 2-4 \mathrm{nM}$ are recommended to stimulate maximum phytoplankton growth due to the rapid losses of added iron by horizontal advection-diffusion and oxidation to poorly bioavailable iron(III) (Coale et al., 1996, 1998; Bowie et al., 2001). For patch size, a biogeochemical model study showed that a fertilized patch size of $156 \mathrm{~km}^{2}$ maintained an iron concentration above $0.3 \mathrm{nM}$ for 56 days, while a longer period of 194 days required a fertilized patch size of $160000 \mathrm{~km}^{2}$ (Xiu and Chai, 2010). As a consequence of expansion and dilution, previous aOIF experiments also produced similar results to this model study. The lateral dilution rate $\left(<0.25 \mathrm{day}^{-1}\right)$ during SAGE, which had the smallest fertilized patch size $\left(36 \mathrm{~km}^{2}\right)$ of the SO experiments, was 2 times higher than the rates $\left(<0.11 \mathrm{day}^{-1}\right)$ in the SO experiments with a larger fertilized patch size (e.g., EIFEX fertilized with a patch size of $167 \mathrm{~km}^{2}$ and SOFeX-S fertilized with a patch size of $225 \mathrm{~km}^{2}$ ) (Coale et al., 2004; Harvey et al., 2010; Law et al., 2011; Smetacek et al., 2012). Therefore, 
it would be more appropriate to fertilize a large area (e.g., LOHAFEX had the largest aOIF experiment at $300 \mathrm{~km}^{2}$ ), which would reduce the dilution effect with unfertilized waters (Xiu and Chai, 2010). Based on a $\sim 2 \mathrm{nM}$ iron concentration for a patch size of $300 \mathrm{~km}^{2}$ and MLD of $\sim 60 \mathrm{~m}$, it would need $\sim 2000 \mathrm{~kg}$ of iron(II) to be applied in a fertilization experiment. Iron should be released into the wake of a ship, with the release track describing an expanding spiral (or square) in the eddy center, with a regular interval of $\sim 1 \mathrm{~km}$ throughout the patch, because it is easier to locate a fertilized patch than a point release (Watson et al., 1991). In addition, it should be completed within $\sim 24 \mathrm{~h}$ because of the timedependent phytoplankton response within the iron-fertilized patch. Previous aOIF experiments have shown that multiple iron additions ( $\geq 2$ infusions) are needed to maintain the dissolved iron concentration required to derive maximum phytoplankton growth within the fertilized patch. For example, in SOIREE it was found that four additions of iron at intervals of about 3 days led to persistently high levels of both dissolved and particulate iron within the ML, with a rapid reduction at the end of the experiment, combined with an increase in the concentration of iron-binding ligands (Bowie et al., 2001). In both EIFEX and SOFeX-S, it was also found that multiple iron(II) infusions (in particular, two infusions with intervals of 13 days in EIFEX and four infusions with intervals of 4 days in SOFeX-S) allowed iron to persist in the ML longer than its expected oxidation kinetics. The relatively low oxidation rates were related to a combination of photochemical production; slow oxidation; and, possibly, organic complexation (Croot et al., 2008). Blain et al. (2007) explained that the higher carbon sequestration effectiveness of nOIF experiments compared to aOIF experiments partly resulted from the slow and continuous iron addition that occurs in the natural environment. Large amounts of iron addition at one time can lead to a substantial loss of artificially added iron. Therefore, for an experimental duration of $>40$ days, a minimum of two or three iron infusions at intervals of $\sim 10-15$ days would be required to prevent the iron limitation on phytoplankton growth, based on the EIFEX experiment (Smetacek et al., 2012).

What. The fifth consideration for a successful aOIF experiment is the effective tracing of the fertilized patch, including the detection of carbon sequestration (Buesseler and Boyd, 2003). The first step in tracing a fertilized patch is to investigate in advance the development and fate of natural blooms appearing as chlorophyll patches using satellite data from pre-experiment investigations. All aOIF experiments used physical tracers to follow the iron-fertilized patches, in particular GPS- and Argos-equipped drifting buoys that provide the tracked positions of a fertilized patch as a passive system moving with local currents. GPS- and Argos-equipped drifting buoys should be released before fertilization (to provide a baseline), and ensuing aOIF experiments should be carried out in the region described by the drifting buoys deployed. Drifting buoys are, however, not perfect representations of water motion and due to the effects of winds are likely to escape a fertilized patch within a few days to a week regardless of how deep their drogues are (Watson et al., 1991; Law et al., 1998; Stanton et al., 1998). An inert chemical tracer, such as $\mathrm{SF}_{6}$, would also be an excellent option for following the fertilized patch after iron addition. Previous aOIF experiments have shown that the $\mathrm{SF}_{6}$ measurements based on underway sampling systems can be used to accurately determine time-dependent vertical and lateral transport of ironfertilized patches. However, tracing via $\mathrm{SF}_{6}$ allows for only a limited period ( $\sim 2$ weeks) due to air-sea gas exchange (Law et al., 2006; Tsumune et al., 2009; Martin et al., 2013). Thus, many subsequent aOIF experiments have also used tracing methods based on the observation of biogeochemical parameters (such as the $F_{\mathrm{v}} / F_{\mathrm{m}}$ ratio, chlorophyll fluorescence, and underway $p \mathrm{CO}_{2}$ ) before and after iron addition (Martin et al., 1994; Coale et al., 1996, 2004; Boyd et al., 2000, 2004; Tsuda et al., 2005; Smetacek et al., 2012). The $F_{\mathrm{v}} / F_{\mathrm{m}}$ ratio can be easily and promptly used as an indicator to track the fertilized patch due to its rapid response to iron addition. Direct measurements of carbon export fluxes to determine the effectiveness of aOIF should be conducted by deploying an NBST at two depths: (1) just below the in situ MLD to detect increases in iron-induced POC in the surface layer along with the calibration of the water-column-based ${ }^{234}$ Th method and (2) at the winter MLD to detect iron-induced carbon export fluxes below winter MLD (Bidigare et al., 1999; Nodder et al., 2001; Boyd et al., 2004; Buesseler et al., 2004, 2005; Coale et al., 2004; Aono et al., 2005; Tsuda et al., 2007; Smetacek et al., 2012; Martin et al., 2013). Sinkingparticle profiling systems (e.g., transmissometers mounted on autonomous floats and gliders) that measure sinking particles could provide a record of the temporal and vertical evolution of iron-induced POC stocks through successive depth layers down to $\sim 3000 \mathrm{~m}$ for $\sim 20$ months after deployment, once calibrated using POC fluxes measured from sediment traps and/or the water-column-based ${ }^{234}$ Th method (Bishop et al., 2004; Smetacek et al., 2012). Repeat casts with UVPs mounted on the rosette could also serve a similar purpose providing a photographic history of the water column (Martin et al., 2013). Future aOIF experiments would benefit from these technological advances, enabling a more efficient tracing of the carbon export flux and particle size and composition at higher vertical and temporal resolution than has been possible in the past. Hence, the application of an NBST system and water-column-based ${ }^{234} \mathrm{Th}$ method to direct flux estimates, combined with autonomous sinking-particle profilers of a transmissometer and an UVP, will enable the quantitative and qualitative evaluation of the effectiveness of aOIF and direct observation of iron-induced carbon export fluxes after artificial iron additions.

What concerns. The sixth consideration for a successful aOIF experiment is the monitoring of possible side effects. The LC/LP parties recently adopted Resolution LCLP.2 (2010), which includes the Assessment Framework for 
Scientific Research Involving Ocean Fertilization. This considers possible side effects on marine/ocean ecosystems after artificial iron additions, such as the production of climaterelevant gases and negative ecosystem changes, which are vital to assess when proposing an aOIF experiment. The emissions of climate-relevant gases, such as $\mathrm{N}_{2} \mathrm{O}$, DMS, and HVOCs, may directly contribute to warming or cooling effects, and oxygen decrease and toxic DA production may have a negative impact on marine/ocean ecosystems (Law, 2008; Silver et al., 2010; Trick et al., 2010; Williamson et al., 2012), resulting in significant offsets against the benefits of aOIF experiments. However, there is little quantitative and qualitative information regarding possible side effects following the previous aOIF experiments. Therefore, the future monitoring of these potential side effects is a prerequisite to evaluate accurately the effectiveness of an aOIF experiment in the future. The possible side effects after an aOIF experiment can be continuously monitored from optical-sensor-equipped autonomous moored profilers and/or autonomous benthic vehicles (e.g., crawler, which is capable of performing long-term benthic oxygen measurements for $\sim 12$ months) (Dunne et al., 2002; Purser et al., 2013; Wenzhöfer et al., 2016).

In summary, to maximize the effectiveness of aOIF experiments in the future, we suggest a design that incorporates several conditions. (1) Experiments are conducted in the center of an eddy structure when grazing pressure is low and silicate levels are high (e.g., in the case of SO, at the south of the PF during the early summer). (2) Shipboard observations are made during a minimum of $\sim 40$ days, with multiple iron injections (iron infusions of $\sim 2000 \mathrm{~kg}$ at least two or three times, with an interval of $\sim 10-15$ days, to fertilize a patch of $300 \mathrm{~km}^{2}$ to obtain a $\sim 2 \mathrm{nM}$ concentration). (3) The ironfertilized patch is traced using both physical (e.g., a drifting buoy) and biogeochemical (e.g., $\mathrm{SF}_{6}$, the $F_{\mathrm{v}} / F_{\mathrm{m}}$ ratio, and online $p \mathrm{CO}_{2}$ measurements) tracers. (4) The NBST system and water-column-derived ${ }^{234} \mathrm{Th}$ method are employed at two depths (i.e., just below the in situ MLD and at the winter MLD), with autonomous profilers equipped with an UVP and a transmissometer to estimate accurately the carbon export flux. (5) The side effects on marine/ocean ecosystems, including decline in oxygen content and the production of climate-relevant gases (e.g., $\mathrm{N}_{2} \mathrm{O}$, DMS, and HVOCs) and toxic DA, are monitored using optical-sensor-equipped autonomous moored profilers and/or autonomous benthic vehicles.

\section{Design of the Korean Iron Fertilization Experiment in the Southern Ocean (KIFES)}

\subsection{A plan for the future: KIFES}

The KIFES design entails a 5-year project plan modeled on the EIFEX program that found deep carbon by conducting an
aOIF experiment in the center of an eddy structure (Fig. 11). The KIFES project would include a preliminary environmental survey both outside and inside the center of an eddy structure formed in the SO PF, a scientific aOIF experiment, and an assessment of the full KIFES project. In this section, we introduce the major goals, objectives, and main tasks of KIFES.

\subsubsection{Year one plan}

Goals. (1) Data collection with regard to oceanographic conditions in the SO PF, including both eddy development and distribution. (2) Establishment of the study aims, hypotheses, and site for the KIFES experiment. (3) Announcement of KIFES plans and intentions to the public.

Objectives. (1) To understand the physical and biogeochemical oceanography of relevance to the SO PF as an aOIF site through an analysis of earlier datasets and a review of published papers. (2) To promote public awareness of the aims of KIFES and its rationale.

Main tasks. (1) Review databases of physical and biogeochemical parameters from previous surveys conducted in the SO PF. (2) Review the SO PF oceanographic conditions using data analysis and references. (3) Establish the study aims, hypotheses, and potential locations in the SO PF for an aOIF experiment, based on the results obtained from tasks (1) and (2). (4) Design an oceanographic cruise map for the first preliminary survey in the SO PF. (5) Study natural blooms appearing as high chlorophyll $a$ concentration patches and their fate using satellite data in the SO PF. (6) Analyze eddy development and distribution in the potential experiment region by carrying out a thorough study of eddy history using satellite sea surface height anomalies. (7) Prepare scientific instruments for ocean physical and biogeochemical monitoring. (8) Establish an international collaborative aOIF network. (9) Distribute a press release announcing KIFES plans and intentions and explain the scientific background to the public via short films and animated cartoons on the role of the ocean in maintaining atmospheric $\mathrm{CO}_{2}$ levels, Martin's hypothesis, and results of previous aOIF experiments. (10) Submit the KIFES field program proposal for the "initial assessment" stage to determine that KIFES falls within the remit of ocean fertilization and should be evaluated in the LC/LP assessment framework based on the results from tasks (1)-(6).

\subsubsection{Year two plan}

Goal. First preliminary hydrographic survey to provide a foundational understanding of oceanographic conditions in the SO PF.

Objectives. (1) To obtain information about oceanographic conditions from in situ measurements in the SO PF. (2) To provide background information before the KIFES experiment. 


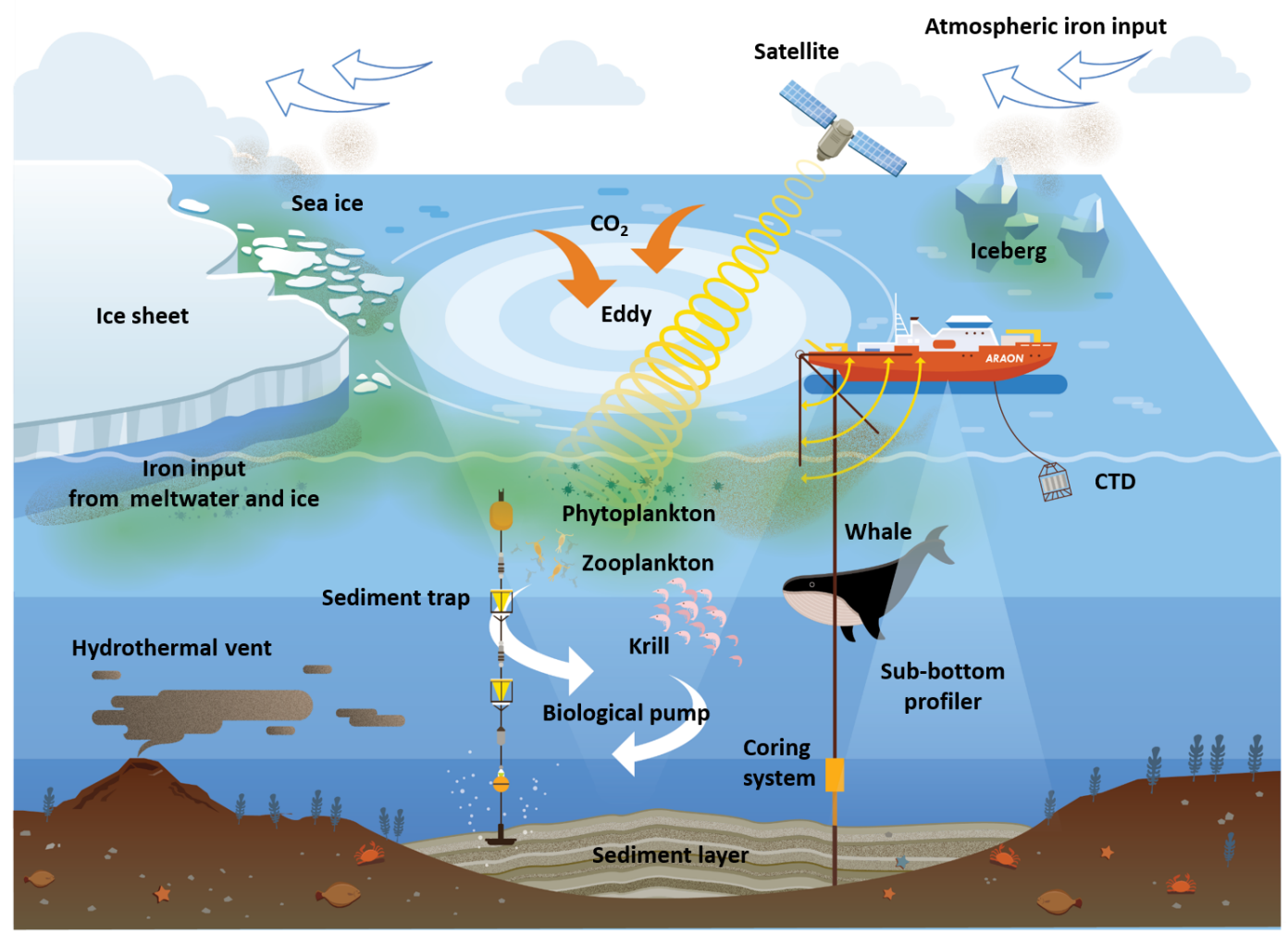

Figure 11. Schematic diagram of the Korean Iron Fertilization Experiment in the Southern Ocean (KIFES) representing the experiment target site (eddy structure) and survey methods (underway sampling systems, multiple sediment traps, sub-bottom profilers, sediment coring systems, and satellite observations).

Main tasks. (1) Using the ice breaker RV ARAON, undertake a field investigation in the SO PF to determine physical and biogeochemical parameters associated with both carbon sequestration and aOIF side effects (e.g., decline in oxygen inventory and production of $\mathrm{N}_{2} \mathrm{O}$, DMS, HVOCs, and DA), based on the first-year results. (2) Prepare an environmental assessment for the LC/LP assessment framework based on the first-year results and a preliminary hydrographic survey.

\subsubsection{Year three plan}

Goals. (1) Preliminary hydrographic survey outside and inside the center of an eddy structure prior to the KIFES experiment. (2) Approval of KIFES from LC/LP. (3) Preparation for making a film on KIFES.

Objectives. (1) To compare oceanographic conditions inside and outside the center of an eddy structure formed in the SO PF prior to the KIFES experiment. (2) To obtain permission on the basis that the proposed KIFES is legitimate scientific research from the LC/LP. (3) To prepare the groundwork for making a documentary film on the KIFES expedition.

Main tasks. (1) Using the ice breaker RV ARAON, detect an eddy formed in the SO PF using observations from acoustic Doppler current profilers (ADCPs) and satellites. (2) Conduct intensive physical and biogeochemical field investiga- tions both inside and outside the center of an eddy structure. (3) Assess the physical and biogeochemical properties outside vs. inside the center of an eddy structure prior to KIFES. (4) Establish a final design for KIFES. (5) Submit the research results for the "environmental assessment" stage of the LC/LP assessment framework and obtain approval for the KIFES experiment via the "decision-making" process from the LC/LP. (6) Contact the director of a Korean science TV channel to make a film about the KIFES expedition.

\subsubsection{Year four plan}

Goal. Conduction of the KIFES scientific aOIF experiment in the center of an eddy structure during the early summertime (Fig. 11).

Objective. To conduct a scientific aOIF experiment in the center of an eddy structure formed in the SO PF.

Main tasks. (1) Using the ice breaker RV ARAON, detect an eddy formed in the SO PF using observations from ADCPs and satellites, and investigate the initial environmental conditions for $\sim 4$ days before KIFES. (2) Execute the KIFES field campaign during a $>40$-day period with the eddy structure. (3) Perform at least two or three iron additions at intervals of $\sim 15$ days, with each iron injection being $\sim 2000 \mathrm{~kg}$ following a spiral ship track, with a regular 
interval of $\sim 1 \mathrm{~km}$ to create a patch size of $300 \mathrm{~km}^{2}$ (target dissolved iron concentration of $\sim 2 \mathrm{nM}$ ). (4) Trace the fertilized patch with deployments of GPS- and Argos-equipped surface-layer-tethered buoys, biogeochemical tracers $\left(\mathrm{SF}_{6}\right.$, the $F_{\mathrm{v}} / F_{\mathrm{m}}$ ratio, and online $p \mathrm{CO}_{2}$ measurements) employing underway-sampling systems, and gliders equipped with biogeochemical sensors. (5) Measure iron-induced carbon export fluxes for the regions both inside and outside the center of an eddy structure using NBST systems at two depths (i.e., just below the in situ MLD and at the winter MLD) along with the calibration of water-column-based ${ }^{234} \mathrm{Th}$ measurements and autonomous profilers equipped with a transmissometer and an UVP. (6) Monitor possible side effects, such as the decline in oxygen contents and the production of climate-relevant gases and toxic DA, using opticalsensor-equipped autonomous moored profilers and/or autonomous benthic vehicles. (7) Monitor continued responses after KIFES termination using satellite observations and autonomous profilers. (8) Assess the effectiveness of carbon sequestration and environmental (ocean and atmosphere) side effects for KIFES and prepare the KIFES assessment for the "results of monitoring" stage of the LC/LP assessment framework. (9) Prepare a documentary film during the KIFES expedition by a Korean government TV channel for a regular series on science for the public.

\subsubsection{Year five plan}

Goal. Integrated assessment of the KIFES project.

Objectives. (1) To determine the effectiveness of artificially iron-induced export production and any negative impacts on climate change. (2) To assess the results on basic processes pertaining to the relationship between pelagic ecology and ocean biogeochemistry.

Main tasks. (1) Submit the KIFES assessment report. (2) Submit scientific results to international journals. (3) Collect feedback regarding the KIFES project from international scientific and oceanographic communities. (4) Produce a final aOIF experimental summary, including main tasks (1)(3). (5) Assess the results for hypothesis testing in the fields of plankton ecology and biogeochemistry using the integrated results of KIFES. (6) Evaluate effectiveness and environmental side effects of large-scale SO aOIF via more realistic simulations under various scenarios with ocean biogeochemical models using the integrated results of KIFES. (7) Submit a final report of the KIFES assessment to the LC/LP.

\subsection{Final remark}

The interests of the KIFES project will be all laid out in the detailed investigation of the biogeochemical effects of scientific aOIF in the $\mathrm{SO}$ and in aOIF as a possible geoengineering method to mitigate the climate change effects we will face in the future. We envisage a future where the KIFES, or sim- ilar projects, can be resumed following the guidelines formulated by the LC/LP, enabling a more robust assessment of the potential of aOIF as a geoengineering solution to help reduce atmospheric $\mathrm{CO}_{2}$ concentrations. A continuation of the next aOIF experiment would provide fundamental information and guidelines for future scientific aOIF experiments in HNLC regions, in addition to improving our understanding of SO pelagic ecology-biogeochemistry. The risks and side effects of aOIF should be thoroughly investigated to calm international concerns. Finally, we emphasize that international cooperation is essential for a project as organizationally and scientifically complex as KIFES and that we seek to improve our knowledge and provide a positive outlook for the Earth's future.

\section{Summary}

To test Martin's hypothesis, a total of 13 scientific aOIF experiments have been conducted in HNLC regions during the last 25 years. These aOIF experiments have resulted in increases in PP and drawdowns of macronutrients and DIC. In most experiments, the phytoplankton group has tended to shift from small-sized to large-sized plankton cells (mostly diatom-dominated). However, their effectiveness in enhancing export production has not been confirmed, except for EIFEX. Likewise, the possible environmental negative side effects in response to iron addition, such as decline in oxygen content and the production of climate-relevant gases and toxic DA, could not be fully evaluated due to the widely differing outcomes, with large uncertainties depending on aOIF experimental conditions and settings. In particular, the monitoring of $\mathrm{N}_{2} \mathrm{O}$, DMS, and HVOCs is essential to determine the effectiveness of aOIF as a geoengineering approach, because these potential trace gas emissions can directly and indirectly modify the carbon reduction benefits resulting from aOIF. Furthermore, oxygen decline and toxic DA production may cause serious damage to marine/ocean ecosystems. Therefore, the validation and suitability of aOIF for the mitigation of rapidly increasing atmospheric $\mathrm{CO}_{2}$ levels are a subject of vigorous debate. At present, large-scale and/or commercial aOIF is prohibited by international regulation, while small-scale aOIF experimentation for scientific purposes is permitted. To maximize the effectiveness of aOIF, future aOIF experiments should be conducted by carefully considering the major factors including the methods for iron addition, tracing methods, measurement parameters, location, timing, and experimental duration, under international aOIF regulations. Finally, we envisage a future where the KIFES project, or a similar alternative, becomes a reality so that we may determine whether aOIF is a promising geoengineering solution for climate change mitigation and/or an adequate experimental tool for hypothesis testing in the fields of plankton ecology and ocean biogeochemistry. 
Data availability. There are no data associated with this publication.

Author contributions. JEY, KCY, KK, and INK made contributes to the concept, design, and preparation of the manuscript. AMM contributed advise on explanations, content, and English. JEY and INK wrote the manuscript. All authors discussed the results and commented on the manuscript.

Competing interests. The authors declare that they have no conflict of interest.

Acknowledgements. We thank two reviewers and Victor Smetacek (Alfred Wegener Institute) for their valuable comments on the manuscript. We thank Eunsil Kim (Sangmyung University) for her help in drawing Fig. 2. Thanks to all the people who contributed to the scientific OIF experiments. This research was a part of the project titled the Korean Iron Fertilization Experiment in the Southern Ocean (KOPRI, PM 16060) funded by the Ministry of Oceans and Fisheries, Korea. This work was partly supported by the National Research Foundation of Korea (NRF) grant funded by the Korea government (MSIP) (no. 2015R1C1A1A01052051); the Korea-Arctic Ocean Observing System project (K-AOOS) (KOPRI, 20160245) funded by the MOF, Korea; and the KOPRI project (PE18200). Alison M. Macdonald was supported by NOAA grant no. NA11OAR4310063 and internal WHOI funding. The last two authors (Il-Nam Kim and Kitae Kim) act as co-corresponding authors for this work.

Edited by: S. W. A. Naqvi

Reviewed by: Victor Smetacek and two anonymous referees

\section{References}

Abbott, M. R., Richman, J. G., and Bartlett, J. S.: The spring bloom in the Antarctic Polar Frontal Zone as observed from a mesoscale array of bio-optical sensors. Deep-Sea Res. Pt. II, 47, 3285-3314, https://doi.org/10.1016/S0967-0645(00)00069-2, 2000.

Abelmann, A., Gersonde, R., Cortese, G., Kuhn, G., and Smetacek, V.: Extensive phytoplankton blooms in the Atlantic sector of the glacial Southern Ocean, Paleoceanography, 21, PA1013, https://doi.org/10.1029/2005PA001199, 2006.

Abraham, E. R., Law, C. S., Boyd, P. W., Lavender, S. J., Maldonado, M. T., and Bowie, A. R.: Importance of stirring in the development of an iron-fertilized phytoplankton bloom, Nature, 407, 727-730, https://doi.org/10.1038/35037555, 2000.

ACE CRC: Position Analysis: Ocean Fertilisation: Science and Policy Issues, ACE CRC, Hobart, 2008.

ACE CRC: Position Analysis: Ocean Fertilisation, ACE CRC, Hobart, 2015.

Aiken, J., Hardman-Mountford, N. J., Barlow, R., Fishwick, J., Hirata, T., and Smyth, T.: Functional links between bioenergetics and bio-optical traits of phytoplankton taxonomic groups: an overarching hypothesis with applications for ocean colour remote sensing, J. Plankton Res., 30, 165-181, https://doi.org/10.1093/plankt/fbm098, 2008.

Anderson, M. A. and Morel, F. M. M.: The influence of aqueous iron chemistry on the uptake of iron by the coastal diatom Thalassiosira weissflogii, Limnol. Oceanogr., 27, 789-813, https://doi.org/10.4319/lo.1982.27.5.0789, 1982.

Aono, T., Yamada, M., Kudo, I., Imai, K., Nojiri, Y., and Tsuda, A.: Export fluxes of particulate organic carbon estimated from ${ }^{234} \mathrm{Th} /{ }^{238} \mathrm{U}$ disequilibrium during the Subarctic Pacific Iron Experiment for Ecosystem Dynamics Study (SEEDS 2001), Prog. Oceanogr., 64, 263-282, https://doi.org/10.1016/j.pocean.2005.02.013, 2005.

Aramaki, T., Nojiri, Y., and Imai, K.: Behavior of particulate materials during iron fertilization experiments in the Western Subarctic Pacific (SEEDS and SEEDS II), Deep-Sea Res. Pt. II, 56, 28752888, https://doi.org/10.1016/j.dsr2.2009.07.005, 2009.

Arrieta, J. M., Weinbauer, M. G., Lute, C., and Herndl, G. J.: Response of bacterioplankton to iron fertilization in the Southern Ocean, Limnol. Oceanogr., 49, 799-808, https://doi.org/10.4319/lo.2004.49.3.0799, 2004.

Assmy, P., Henjes, J., Klaas, C., and Smetacek, V.: Mechanisms determining species dominance in a phytoplankton bloom induced by the iron fertilization experiment EisenEx in the Southern Ocean, Deep-Sea Res. Pt. I, 54, 340-362, https://doi.org/10.1016/j.dsr.2006.12.005, 2007.

Assmy, P., Smetacek, V., Montresor, M., Klaas, C., Henjes, J., Strass, V. H., Arrieta, J. M., Bathmann, U., Berg, G. M., Breitbarth, E., Cisewski, B., Friedrichs, L., Fuchs, N., Herndl, G. J., Jansen, S., Kragefsky, S., Latasa, M., Peeken, I., Rottgers, R., Scharek, R., Schuller, S. E., Steigenberger, S., Webb, A., and Wolf-Gladrow, D.: Thick-shelled, grazer-protected diatoms decouple ocean carbon and silicon cycles in the iron-limited Antarctic Circumpolar Current, P. Natl. Acad. Sci. USA, 110, 20633-20638, https://doi.org/10.1073/pnas.1309345110, 2013.

Aumont, O. and Bopp, L.: Globalizing results from ocean in situ iron fertilization studies, Global Biogeochem. Cy., 20, GB2017, https://doi.org/10.1029/2005GB002591, 2006.

Bakker, D. C. E., Watson, A. J., and Law, C. S.: Southern Ocean iron enrichment promotes inorganic carbon drawdown, DeepSea Res. Pt. II, 48, 2483-2507, https://doi.org/10.1016/S09670645(01)00005-4, 2001.

Bakker, D. C. E., Bozec, Y., Nightingale, P. D., Goldson, L., Messias, M.-J., de Baar, H. J. W., Liddicoat, M., Skjelvan, I., Strass, V., and Watson, A. J.: Iron and mixing affect biological carbon uptake in SOIREE and EisenEx, two Southern Ocean iron fertilisation experiments, Deep-Sea Res. Pt. I, 52, 1001-1019, https://doi.org/10.1016/j.dsr.2004.11.015, 2005.

Bange, H. W.: New Directions: The importance of oceanic nitrous oxide emissions, Atmos. Environ., 40, 198-199, https://doi.org/10.1016/j.atmosenv.2005.09.030, 2006.

Barber, R. T. and Hiscock, M. R.: A rising tide lifts all phytoplankton: Growth response of other phytoplankton taxa in diatomdominated blooms, Global Biogeochem. Cy., 20, GB4S03, https://doi.org/10.1029/2006GB002726, 2006.

Barnola, J. M., Raynaud, D., Korotkevich, Y. S., and Lorius, C.: Vostok ice core provides 160,000-year record of atmospheric $\mathrm{CO}_{2}$, Nature, 329, 408-414, https://doi.org/10.1038/329408a0, 1987. 
Behrenfeld, M. J., Bale, A. J., Kolber, Z. S., Aiken, J., and Falkowski, P. G.: Confirmation of Iron Limitation of Phytoplankton Photosynthesis in the Equatorial Pacific-Ocean, Nature, 383, 508-511, https://doi.org/10.1038/383508a0, 1996.

Belviso, S., Bopp, L., Mosseri, J., Tedetti, M., Garcia, N., Griffiths, B., Joux, F., Obernosterer, I., Uitz, J., and Veldhuis, M. J. W. Effect of natural iron fertilisation on the distribution of DMS and DMSP in the Indian sector of the Southern Ocean, Deep-Sea Res. Pt. II, 55, 893-900, https://doi.org/10.1016/j.dsr2.2007.12.040, 2008.

Berg, G. M., Mills, M. M., Long, M. C., Bellerby, R., Strass, V., Savoye, N., Rottgers, R., Croot, P. L., Webb, A., and Arrigo, $\mathrm{K}$. R.: Variation in particulate $\mathrm{C}$ and $\mathrm{N}$ isotope composition following iron fertilization in two successive phytoplankton communities in the Southern Ocean, Global Biogeochem. Cy., 25, GB3013, https://doi.org/10.1029/2010GB003824, 2011.

Bidigare, R. R., Hanson, K. L., Buesseler, K. O., Wakeham, S. G., Freeman, K. H., Pancost, R. D., Millero, F. J., Steinberg, P., Popp, B. N., Latasa, M., Landry, M. R., and Laws, E. A.: Iron-stimulated changes in ${ }^{13} \mathrm{C}$ fractionation and export by equatorial Pacific phytoplankton: Toward a paleogrowth rate proxy, Paleoceanography, 14, 589-595, https://doi.org/10.1029/1999PA900026, 1999.

Bishop, J. K. B., Wood, T. J., Davis, R. E., and Sherman, J. T.: Robotic Observations of Enhanced Carbon Biomass and Export at $55^{\circ} \mathrm{S}$ During SOFeX, Science, 304, 417-420, https://doi.org/10.1126/science.1087717, 2004.

Blain, S., Queguiner, B., Armand, L., Belviso, S., Bombled, B., Bopp, L., Bowie, A., Brunet, C., Brussaard, C., Carlotti, F., Christaki, U., Corbiere, A., Durand, I., Ebersbach, F., Fuda, J.L., Garcia, N., Gerringa, L., Griffiths, B., Guigue, C., Guillerm, C., Jacquet, S., Jeandel, C., Laan, P., Lefevre, D., Lo Monaco, C., Malits, A., Mosseri, J., Obernosterer, I., Park, Y.-H., Picheral, M., Pondaven, P., Remenyi, T., Sandroni, V., Sarthou, G., Savoye, N., Scouarnec, L., Souhaut, M., Thuiller, D., Timmermans, K., Trull, T., Uitz, J., van Beek, P., Veldhuis, M., Vincent, D., Viollier, E., Vong, L., and Wagener, T.: Effect of natural iron fertilization on carbon sequestration in the Southern Ocean, Nature, 446, 10701074, https://doi.org/10.1038/nature05700, 2007.

Blain, S., Sarthou, G., and Laan, P.: Distribution of dissolved iron during the natural iron-fertilization experiment KEOPS (Kerguelen Plateau, Southern Ocean), Deep-Sea Res. Pt. II, 55, 594-605, https://doi.org/10.1016/j.dsr2.2007.12.028, 2008.

Blain, S., Capparos, J., Guéneuguès, A., Obernosterer, I., and Oriol, L.: Distributions and stoichiometry of dissolved nitrogen and phosphorus in the iron-fertilized region near Kerguelen (Southern Ocean), Biogeosciences, 12, 623-635, https://doi.org/10.5194/bg-12-623-2015, 2015.

Bopp, L., Aumont, O., Belviso, S., and Blain, S.: Modelling the effect of iron fertilization on dimethylsulphide emissions in the Southern Ocean, Deep-Sea Res. Pt. II, 55, 901-912, https://doi.org/10.1016/j.dsr2.2007.12.002, 2008.

Bowie, A. R., Maldonado, M. T., Frew, R. D., Croot, P. L., Achterberg, E. P., Mantoura, R. F. C., Worsfold, P. J., Law, C. S., and Boyd, P. W.: The fate of added iron during a mesoscale fertilisation experiment in the Southern Ocean, Deep-Sea Res. Pt. II, 48, 2703-2743, https://doi.org/10.1016/S0967-0645(01)000157, 2001 .
Boyd, P. W.: The role of iron in the biogeochemistry of the Southern Ocean and equatorial Pacific: a comparison of in situ iron enrichments, Deep-Sea Res. Pt. II, 49, 1803-1821, https://doi.org/10.1016/S0967-0645(02)00013-9, 2002.

Boyd, P. W. and Abraham, E. R.: Iron-mediated changes in phytoplankton photosynthetic competence during SOIREE, DeepSea Res. Pt. II, 48, 2529-2550, https://doi.org/10.1016/S09670645(01)00007-8, 2001.

Boyd, P. W. and Law, C. S.: The Southern Ocean Iron RElease Experiment (SOIREE) - introduction and summary, DeepSea Res. Pt. II, 48, 2425-2438, https://doi.org/10.1016/S09670645(01)00002-9, 2001.

Boyd, P. W., Watson, A. J., Law, C. S., Abraham, E. R., Trull, T., Murdoch, R., Bakker, D. C. E., Bowie, A. R., Buesseler, K. O., Chang, H., Charette, M., Croot, P., Downing, K., Frew, R., Gall, M., Hadfield, M., Hall, J., Harvey, M., Jameson, G., LaRoche, J., Liddicoat, M., Ling, R., Maldonado, M. T., McKay, R. M., Nodder, S., Pickmere, S., Pridmore, R., Rintoul, S., Safi, K., Sutton, P., Strzepek, R., Tanneberger, K., Turner, S., Waite, A., and Zeldis, J.: A mesoscale phytoplankton bloom in the polar Southern Ocean stimulated by iron fertilization, Nature, 407, 695-702, https://doi.org/10.1038/35037500, 2000.

Boyd, P. W., Law, C. S., Wong, C. S., Nojiri, Y., Tsuda, A., Levasseur, M., Takeda, S., Rivkin, R., Harrison, P. J., Strzepek, R., Gower, J., McKay, R. M., Abraham, E., Arychuk, M., BarwellClarke, J., Crawford, W., Crawford, D., Hale, M., Harada, K., Johnson, K., Kiyosawa, H., Kudo, I., Marchetti, A., Miller, W., Needoba, J., Nishioka, J., Ogawa, H., Page, J., Robert, M., Saito, H., Sastri, A., Sherry, N., Soutar, T., Sutherland, N., Taira, Y., Whitney, F., Wong, S.-K. E., and Yoshimura, T.: The decline and fate of an iron-induced subarctic phytoplankton bloom, Nature, 428, 549-553, https://doi.org/10.1038/nature02437, 2004.

Boyd, P. W., Strzepek, R., Takeda, S., Jackson, G., Wong, C. S., McKay, R. M., Law, C., Kiyosawa, H., Saito, H., Sherry, N., Johnson, K., Gower, J., and Ramaiah, N.: The evolution and termination of an iron-induced mesoscale bloom in the northeast subarctic Pacific, Limnol. Oceanogr., 50, 1872-1886, https://doi.org/10.4319/lo.2005.50.6.1872, 2005.

Boyd, P. W., Jickells, T., Law, C. S., Blain, S., Boyle, E. A., Buesseler, K. O., Coale, K. H., Cullen, J. J., de Baar, H. J. W., Follows, M., Harvey, M., Lancelot, C., Levasseur, M., Owens, N. P. J., Pollard, R., Rivkin, R. B., Sarmiento, J., Schoemann, V., Smetacek, V., Takeda, S., Tsuda, A., Turner, S., and Watson, A. J.: Mesoscale Iron Enrichment Experiments 19932005: Synthesis and Future Directions, Science, 315, 612-617, https://doi.org/10.1126/science.1131669, 2007.

Bozec, Y., Bakker, D. C. E., Hartmann, C., Thomas, H., Bellerby, R. G. J., Nightingale, P. D., Riebesell, U., Watson, A. J., and de Baar, H. J. W.: The $\mathrm{CO}_{2}$ system in a Redfield context during an iron enrichment experiment in the Southern Ocean, Mar. Chem., 95, 89-105, https://doi.org/10.1016/j.marchem.2004.08.004, 2005.

Brand, L. E.: Minimum iron requirements in marine phytoplankton and the implications for the biogeochemical control of new production, Limnol. Oceanogr., 36, 1756-1772, https://doi.org/10.4319/lo.1991.36.8.1756, 1991.

Briggs, N., Perry, M. J., Cetinić, I., Lee, C., D’Asaro, E., Gray, A. M., and Rehm, E.: High-resolution observations of aggregate flux during a sub-polar North Atlantic spring bloom, Deep-Sea Res. 
Pt. I, 58, 1031-1039, https://doi.org/10.1016/j.dsr.2011.07.007, 2011.

Broecker, W. S.: Ocean chemistry during glacial time, Geochim. Cosmochim. Ac., 46, 1689-1705, https://doi.org/10.1016/00167037(82)90110-7, 1982.

Broecker, W. S. and Henderson, G. M.: The sequence of events surrounding Termination II and their implications for the cause of glacial-interglacial $\mathrm{CO}_{2}$ changes, Paleoceanography, 13, 352364, https://doi.org/10.1029/98PA00920, 1998.

Buesseler, K. O.: Do upper-ocean sediment traps provide an accurate record of particle flux?, Nature, 353, 420-423, https://doi.org/10.1038/353420a0, 1991.

Buesseler, K. O.: The decoupling of production and particulate export in the surface ocean, Global Biogeochem. Cy., 12, 297-310, https://doi.org/10.1029/97GB03366, 1998.

Buesseler, K. O. and Boyd, P. W.: Will Ocean Fertilization Work?, Science, 300, 67-68, https://doi.org/10.1126/science.1082959, 2003.

Buesseler, K. O., Steinberg, D. K., Michaels, A. F., Johnson, R. J., Andrews, J. E., Valdes, J. R., and Price, J. F.: A comparison of the quantity and quality of material caught in a neutrally buoyant versus surface-tethered sediment trap, Deep-Sea Res. Pt. I, 47, 277294, https://doi.org/10.1016/s0967-0637(99)00056-4, 2000.

Buesseler, K. O., Andrews, J. E., Pike, S. M., and Charette, M. A.: The Effects of Iron Fertilization on Carbon Sequestration in the Southern Ocean, Science, 304, 414-417, https://doi.org/10.1126/science.1086895, 2004.

Buesseler, K. O., Andrews, J. E., Pike, S. M., Charette, M. A., Goldson, L. E., Brzezinski, M. A., and Lance, V. P.: Particle export during the Southern Ocean Iron Experiment (SOFeX), Limnol. Oceanogr., 1, 311-327, https://doi.org/10.4319/lo.2005.50.1.0311, 2005.

Buesseler, K. O., Benitez-Nelson, C. R., Moran, S. B., Burd, A., Charette, M., Cochran, J. K., Coppola, L., Fisher, N. S., Fowler, S. W., Gardner, W. D., Guo, L. D., Gustafsson, O., Lamborg, C., Masque, P., Miquel, J. C., Passow, U., Santschi, P. H., Savoye, N., Stewart, G., and Trull, T.: An assessment of particulate organic carbon to thorium-234 ratios in the ocean and their impact on the application of ${ }^{234} \mathrm{Th}$ as a POC flux proxy, Mar. Chem., 100, 213-233, https://doi.org/10.1016/j.marchem.2005.10.013, 2006.

Buesseler, K. O., Antia, A. N., Chen, M., Fowler, S. W., Gardner, W. D., Gustafsson, O., Harada, K., Michaels, A. F., Rutgers v. d. Loeff, M., Sarin, M., Steinberg, D. K., and Trull, T.: An assessment of the use of sediment traps for estimating upper ocean particle fluxes, J. Mar. Res., 65, 345-416, https://doi.org/10.1357/002224007781567621, 2007.

Butler, W. L.: Energy Distribution in the Photochemical Apparatus of Photosynthesis, Ann. Rev. Plant Physio., 29, 345-378, https://doi.org/10.1146/annurev.pp.29.060178.002021, 1978.

Cavagna, A. J., Fripiat, F., Dehairs, F., Wolf-Gladrow, D., Cisewski, B., Savoye, N., Andre, L., and Cardinal, D.: Silicon uptake and supply during a Southern Ocean iron fertilization experiment (EIFEX) tracked by $\mathrm{Si}$ isotopes, Limnol. Oceanogr., 56, 147160, https://doi.org/10.4319/lo.2011.56.1.0147, 2011.

Cavender-Bares, K. K., Mann, E. L., Chisholm, S. W., Ondrusek, M. E., and Bidigare, R. R.: Differential response of equatorial Pacific phytoplankton to iron fertilization, Limnol. Oceanogr., 44, 237246, https://doi.org/10.4319/lo.1999.44.2.0237, 1999.
Charette, M. A. and Buesseler, K. O.: Does iron fertilization lead to rapid carbon export in the Southern Ocean?, Geochem. Geophys. Geosyst., 1, 2000GC000069, https://doi.org/10.1029/2000GC000069, 2000.

Charlson, R. J., Lovelock, J. E., Andreae, M. O., and Warren, S. G.: Oceanic phytoplankton, atmospheric sulphur, cloud albedo and climate, Nature, 326, 655-661, https://doi.org/10.1038/326655a0, 1987.

Chisholm, S. W., Falkowski, P. G., and Cullen, J. J.: DisCrediting Ocean Fertilization, Science, 294, 309-310, https://doi.org/10.1126/science.1065349, 2001.

Cisewski, B., Strass, V. H., Losch, M., and Prandke, H.: Mixed layer analysis of a mesoscale eddy in the Antarctic Polar Front Zone, J. Geophys. Res., 113, C05017, https://doi.org/10.1029/2007JC004372, 2008.

Coale, K. H. and Bruland, K. W.: ${ }^{234} \mathrm{Th}:{ }^{238} \mathrm{U}$ disequilibria within the California Current, Limnol. Oceanogr., 30, 22-33, https://doi.org/10.4319/lo.1985.30.1.0022, 1985.

Coale, K. H., Johnson, K. S., Fitzwater, S. E., Gordon, R. M., Tanner, S., Chavez, F. P., Ferioli, L., Sakamoto, C., Rogers, P., Millero, F., Steinberg, P., Nightingale, P., Cooper, D., Cochlan, W. P., Landry, M. R., Constantinou, J., Rollwagen, G., Trasvina, A., and Kudela, R.: A massive phytoplankton bloom induced by an ecosystem-scale iron fertilization experiment in the equatorial Pacific Ocean, Nature, 383, 495-501, https://doi.org/10.1038/383495a0, 1996.

Coale, K. H., Johnson, K. S., Fitzwater, S. E., Blain, S. P. G., Stanton, T. P., and Coley, T. L.: IronEx-I, an in situ iron-enrichment experiment: Experimental design, implementation and results, Deep-Sea Res. Pt. II, 45, 919-945, https://doi.org/10.1016/S0967-0645(98)00019-8, 1998.

Coale, K. H., Johnson, K. S., Chavez, F. P., Buesseler, K. O., Barber, R. T., Brzezinski, M. A., Cochlan, W. P., Millero, F. J., Falkowski, P. G., Bauer, J. E., Wanninkhof, R. H., Kudela, R. M., Altabet, M. A., Hales, B. E., Takahashi, T., Landry, M. R., Bidigare, R. R., Wang, X., Chase, Z., Strutton, P. G., Friederich, G. E., Gorbunov, M. Y., Lance, V. P., Hilting, A. K., Hiscock, M. R., Demarest, M., Hiscock, W. T., Sullivan, K. F., Tanner, S. J., Gordon, R. M., Hunter, C. N., Elrod, V. A., Fitzwater, S. E., Jones, J. L., Tozzi, S., Koblizek, M., Roberts, A. E., Herndon, J., Brewster, J., Ladizinsky, N., Smith, G., Cooper, D., Timothy, D., Brown, S. L., Selph, K. E., Sheridan, C. C., Twining, B. S., and Johnson, Z. I.: Southern Ocean Iron Enrichment Experiment: Carbon Cycling in High- and Low-Si Waters, Science, 304, 408414, https://doi.org/10.1126/science.1089778, 2004.

Cochlan, W. P.: The heterotrophic bacterial response during a mesoscale iron enrichment experiment (IronEx II) in the eastern Equatorial Pacific Ocean, Limnol. Oceanogr., 46, 428-435, https://doi.org/10.4319/lo.2001.46.2.0428, 2001.

Cooper, D. J., Watson, A. J., and Nightingale, P. D.: Large decrease in ocean-surface $\mathrm{CO}_{2}$ fugacity in response to in situ iron fertilization, Nature, 383, 511-513, https://doi.org/10.1038/383511a0, 1996.

Croot, P. L., Bluhm, K., Schlosser, C., Streu, P., Breitbarth, E., Frew, R., and Van Ardelan, M.: Regeneration of Fe(II) during EIFeX and SOFeX, Geophys. Res. Lett., 35, L19606, https://doi.org/10.1029/2008GL035063, 2008. 
Cullen, J. J.: Status of the iron hypothesis after the Open-Ocean Enrichment Experiment, Limnol. Oceanogr., 40, 1336-1343, https://doi.org/10.4319/1o.1995.40.7.1336, 1995.

Currie, K. I., Macaskill, B., Reid, M. R., and Law, C. S.: Processes governing the carbon chemistry during the SAGE experiment, Deep-Sea Res. Pt. II, 58, 851-860, https://doi.org/10.1016/j.dsr2.2010.10.023, 2011.

Dacey, J. W. H. and Wakeham, S. G.: Oceanic dimethylsulfide: production during zooplankton grazing on phytoplankton, Science, 233, 1314-1316, https://doi.org/10.1126/science.233.4770.1314, 1986.

Dall'Olmo, G. and Mork, K. A.: Carbon export by small particles in the Norwegian Sea, Geophys. Res. Lett., 41, 2921-2927, https://doi.org/10.1002/2014GL059244, 2014.

de Baar, H. J. W., de Jong, J. T. M., Bakker, D. C. E., Loscher, B. M., Veth, C., Bathmann, U., and Smetacek, V.: Importance of iron for plankton blooms and carbon dioxide drawdown in the Southern Ocean, Nature, 373, 412-415, https://doi.org/10.1038/373412a0, 1995.

de Baar, H. J. W., Boyd, P. W., Coale, K. H., Landry, M. R., Tsuda, A., Assmy, P., Bakker, D. C. E., Bozec, Y., Barber, R. T., Brzezinski, M. A., Buesseler, K. O., Boye, M., Croot, P. L., Gervais, F., Gorbunov, M. Y., Harrison, P. J., Hiscock, W. T., Laan, P., Lancelot, C., Law, C. S., Levasseur, M., Marchetti, A., Millero, F. J., Nishioka, J., Nojiri, Y., van Oijen, T., Riebesell, U., Rijkenberg, M. J. A., Saito, H., Takeda, S., Timmermans, K. R., Veldhuis, M. J. W., Waite, A. M., and Wong, C.-S.: Synthesis of iron fertilization experiments: From the Iron Age in the Age of Enlightenment, J. Geophys. Res., 110, C09S16, https://doi.org/10.1029/2004JC002601, 2005.

De La Rocha, C. L.: The Biological Pump, in: Treatise on Geochemistry update, edited by: Holland, H. D. and Turekian, K. K., Elsevier Pergamon, Oxford, 1-29, https://doi.org/10.1016/B008-043751-6/06107-7, 2007.

Denman, K. L.: Climate change, ocean processes and ocean iron fertilization, Mar. Ecol.-Prog. Ser., 364, 219-225, https://doi.org/10.3354/meps07542, 2008.

DiTullio, G. R., Hutchins, D. A., and Bruland, K. W.: Interaction of iron and major nutrients controls phytoplankton growth and species composition in the tropical North Pacific Ocean, Limnol. Oceanogr., 38, 495-508, https://doi.org/10.4319/lo.1993.38.3.0495, 1993.

Duce, R. A. and Tindale, N. W.: Atmospheric transport of iron and its deposition in the ocean, Limnol. Oceanogr., 36, 1715-1726, https://doi.org/10.4319/lo.1991.36.8.1715, 1991.

Dunne, J. P., Devol, A. H., and Emerson, S.: The Oceanic Remote Chemical/Optical Analyzer (ORCA) - An Autonomous Moored Profiler, J. Atmos. Oceanic Technol., 19, 1709-1721, https://doi.org/10.1175/15200426(2002)019<1709:TORCOA>2.0.CO;2, 2002.

Ebersbach, F., Assmy, P., Martin, P., Schulz, I., Wolzenburg, S., and Nothig, E.-M.: Particle flux characterisation and sedimentation patterns of protistan plankton during the iron fertilisation experiment LOHAFEX in the Southern Ocean, Deep-Sea Res. Pt. I, 89, 94-103, https://doi.org/10.1016/j.dsr.2014.04.007, 2014.

Faghmous, J. H., Frenger, I., Yao, Y., Warmka, R., Lindell, A., and Kumar, V.: A daily global mesoscale ocean eddy dataset from satellite altimetry, Sci. Data, 2, 150028, https://doi.org/10.1038/sdata.2015.28, 2015.
Falkowski, P. G.: Evolution of the nitrogen cycle and its influence on the biological sequestration of $\mathrm{CO}_{2}$ in the ocean, Nature, 387, 272-275, https://doi.org/10.1038/387272a0, 1997.

Farías, L., Florez-Leiva, L., Besoain, V., Sarthou, G., and Fernández, C.: Dissolved greenhouse gases (nitrous oxide and methane) associated with the naturally iron-fertilized Kerguelen region (KEOPS 2 cruise) in the Southern Ocean, Biogeosciences, 12, 1925-1940, https://doi.org/10.5194/bg-12-1925-2015, 2015.

Fine, R. A.: Observations of CFCs and $\mathrm{SF}_{6}$ as Ocean Tracers, Annu. Rev. Mar. Sci., 3, 173-195, https://doi.org/10.1146/annurev.marine.010908.163933, 2011.

Fitzwater, S. E., Coale, K. H., Gordon, R. M., Johnson, K. S., and Ondrusek, M. E.: Iron deficiency and phytoplankton growth in the equatorial Pacific, Deep-Sea Res. Pt. II, 43, 995-1015, https://doi.org/10.1016/0967-0645(96)00033-1, 1996.

Forster, P., Ramaswamy, V., Artaxo, P., Berntsen, T., Betts, R., Fahey, D. W., Haywood, J., Lean, J., Lowe, D. C., Myhre, G., Nganga, J., Prinn, R., Raga, G., Schultz, M., and Van Dorland, R.: Changes in atmospheric constituents and in radiative forcing, Cambridge, United Kingdom, Cambridge University Press, 129234, 2007.

Freestone, D. and Rayfuse, R. G.: Iron Ocean Fertilization and International Law, Mar. Ecol. Prog. Ser., 364, 227-233, https://doi.org/10.3354/meps07543, 2008

Frew, R. D., Bowie, A. R., Croot, P. L., and Pickmere, S.: Macronutrient and trace-metal geochemistry of an in situ iron-induced Southern Ocean bloom, Deep-Sea Res. Pt. II, 48, 2467-2481, https://doi.org/10.1016/S0967-0645(01)00004-2, 2001.

Frost, B. W.: Phytoplankton bloom on iron rations, Nature, 383, 475-476, https://doi.org/10.1038/383475a0, 1996.

Fuhrman, J. A. and Capone, D. G.: Possible biogeochemical consequences of ocean fertilization, Limnol. Oceanogr., 36, 19511959, https://doi.org/10.4319/lo.1991.36.8.1951, 1991.

Gall, M. P., Boyd, P. W., Hall, J., Safi, K. A., and Chang, H.: Phytoplankton processes. Part 1: community structure during the Southern Ocean iron release experiment (SOIREE), DeepSea Res. Pt. II, 48, 2551-2570, https://doi.org/10.1016/S09670645(01)00008-X, 2001a.

Gall, M. P., Strzepek, R., Maldonado, M., and Boyd, P. W.: Phytoplankton processes. Part 2: Rates of primary production and factors controlling algal growth during the Southern Ocean Iron RElease Experiment (SOIREE), Deep-Sea Res. Pt. II, 48, 2571 2590, https://doi.org/10.1016/S0967-0645(01)00009-1, 2001b.

Gardner, W. D., Hinga, K. R., and Marra, J.: Observations on the degradation of biogenic material in the deep ocean with implications on the accuracy of sediment trap fluxes, J. Mar. Res., 41, 195-214, https://doi.org/10.1357/002224083788520180, 1983.

Gerringa, L. J. A., Alderkamp, A.-C., Laan, P., Thuroczy, C.E., De Baar, H. J. W., Mills, M. M., van Dijken, G. L., Haren, H. V., and Arrigo, K. R.: Iron from melting glaciers fuels the phytoplankton blooms in Amundsen Sea (Southern Ocean): Iron biogeochemistry, Deep-Sea Res. Pt. II, 71-76, 1631, https://doi.org/10.1016/j.dsr2.2012.03.007, 2012.

Gervais, F., Riebesell, U., and Gorbunov, M. Y.: Changes in primary productivity and chlorophyll $a$ in response to iron fertilization in the Southern Polar Frontal Zone, Limnol. Oceanogr., 47, 1324 1335, https://doi.org/10.4319/lo.2002.47.5.1324, 2002.

Gnanadesikan, A., Sarmiento, J. L., and Slater, R. D.: Effects of patchy ocean fertilization on atmospheric carbon dioxide 
and biological production, Global Biogeochem. Cy., 17, 1050, https://doi.org/10.1029/2002GB001940, 2003.

Gordon, R. M., Johnson, K. S., and Coale, K. H.: The behaviour of iron and other trace elements during the IronEx-I and PlumEx experiments in the Equatorial Pacific, Deep-Sea Res. Pt. II, 45, 995-1041, https://doi.org/10.1016/S0967-0645(98)00012-5, 1998.

Hadfield, M. G.: Expected and observed conditions during the SAGE iron addition experiment in Subantarctic waters, Deep-Sea Res. Pt. II, 58, 764-775, https://doi.org/10.1016/j.dsr2.2010.10.016, 2011.

Hall, J. A. and Safi, K.: The impact of in situ Fe fertilisation on the microbial food web in the Southern Ocean, Deep-Sea Res. Pt. II, 48, 2591-2613, https://doi.org/10.1016/S0967-0645(01)000108, 2001.

Harvey, M. J., Law, C. S., Smith, M. J., Hall, J. A., Abraham, E. R., Stevens, C. L., Hadfield, M. G., Ho, D. T., Ward, B., Archer, S. D., Cainey, J. M., Currie, K. I., Devries, D., Ellwood, M. J., Hill, P., Jones, G. B., Katz, D., Kuparinen, J., Macaskill, B., Main, W., Marriner, A., McGregor, J., McNeil, C., Minnett, P. J., Nodder, S. D., Peloquin, J., Pickmere, S., Pinkerton, M. H., Safi, K. A., Thompson, R., Walkington, M., Wright, S. W., and Ziolkowski, L. A.: The SOLAS air-sea gas exchange experiment (SAGE) 2004, Deep-Sea Res. Pt. II, 58, 753-763, https://doi.org/10.1016/j.dsr2.2010.10.015, 2010.

Hauck, .J., Kohler, P., Wolf-Gladrow, D., and Volker, C.: Iron fertilisation and century-scale effects of open ocean dissolution of olivine in a simulated $\mathrm{CO}_{2}$ removal experiment, Environ. Res. Lett., 11, 024007, https://doi.org/10.1088/17489326/11/2/024007, 2016.

Hiscock, W. T. and Millero, F. J.: Nutrient and carbon parameters during the Southern Ocean iron experiment (SOFeX), Deep-Sea Res. Pt. I, 52, 2086-2108, https://doi.org/10.1016/j.dsr.2005.06.010, 2005.

Hoffmann, L. J., Peeken, I., Lochte, K., Assmy, P., and Veldhuis, M.: Different reactions of Southern Ocean phytoplankton size classes to iron fertilization, Limnol. Oceanogr., 51, 1217-1229, https://doi.org/10.4319/1o.2006.51.3.1217, 2006.

Hudson, J. M. and Morel, F. M. M.: Iron transport in marine phytoplankton: kinetics and cellular and medium coordination reactions, Limnol. Oceanogr., 35, 1002-1020, https://doi.org/10.4319/1o.1990.35.5.1002, 1990.

Hunt, B. P. V. and Hosie, G. W.: The seasonal succession of zooplankton in the Southern Ocean south of Australia, part II: The Sub-Antarctic to Polar Frontal Zones, Deep-Sea Res. Pt. I, 53, 1203-1223, https://doi.org/10.1016/j.dsr.2006.05.001, 2006.

Hutchins, D. A., Ditullio, G. R., and Bruland, K. W.: Iron and regenerated production: Evidence for biological iron recycling in two marine environments, Limnol. Oceanogr., 38, 1242-1255, https://doi.org/10.4319/lo.1993.38.6.1242, 1993.

IPCC: Climate Change: The IPCC Scientific Assessment of Climate Change, edited by: Houghton, J. T., Jenkins, G. J., and Ephraums, J. J., Cambridge Univ. Press, Cambridge, 1990.

IPCC: Climate Change 1992: The Supplementary Report to the IPCC Scientific Assessment, edited by: Houghton, J. T., Callander, B. A., and Varney, S. K., Cambridge Univ. Press, 1992.

IPCC: Climate Change 1995: The Science of Climate Change, Contribution of Working Group 1 to the Second Assessment Report of the Intergovernmental Panel on Climate Change, edited by:
Houghton, J. T., Meira Filho, L. G., Callander, B. A., Harris, N., Kattenberg, A., and Maskell, K., Cambridge Univ. Press, Cambridge, 1995.

IPCC: Emissions scenarios: special report of Working Group III of the Intergovernmental Panel on Climate Change, edited by: Nakicenovic, N. and Swart, R., Cambridge Univ. Press, Cambridge, 2000.

IPCC: Climate Change 2001: The Scientific Basis, Contribution of Working Group 1 to the Third Assessment Report of the Intergovernmental Panel on Climate Change, edited by: Griggs, D. J., Noguer, M., van der Linden, P. J., Dai, X., Maskell, K., and Johnson, C. A., Cambridge Univ. Press, Cambridge, 2001.

IPCC: Climate Change 2007: Mitigation of Climate Change, Contribution of Working Group III to the Fourth Assessment Report of the Intergovernmental Panel on Climate Change, edited by: Metz, B., Davidson, O. R., Bosch, P. R., Dave, R., Meyer, L. A., Cambridge Univ. Press, Cambridge, 2007.

IPCC: Climate Change 2013: The Physical Science Basis, Contribution of Working Group I to the Fifth Assessment Report of the Intergovernmental Panel on Climate Change, edited by: Stocker, T. F., Qin, D., Plattner, G.-K., Tignor, M., Allen, S. K., Boschung, J., Nauels, A., Xia, Y., Bex, V., and Midgley, P. M., Cambridge Univ. Press, Cambridge, 2013.

IPCC: Climate Change 2014: Mitigation of Climate Change, Contribution of Working Group III to the Fifth Assessment Report of the Intergovernmental Panel on Climate Change, edited by: Edenhofer, O., Pichs-Madruga, R., Sokona, Y., Farahani, E., Kadner, S., Seyboth, K., Adler, A., Baum, I., Brunner, S., Eickemeier, P., Kriemann, B., Savolainen, J., Schlomer, S., von Stechow, C., Zwickel, T., and Minx, J. C., Cambridge Univ. Press, Cambridge, 2014.

Jacquet, S. H. M., Savoye, N., Dehairs, F., Strass, V. H., and Cardinal, D.: Mesopelagic carbon remineralization during the European Iron Fertilization Experiment, Global Biogeochem. Cy., 22, GB1023, https://doi.org/10.1029/2006GB002902, 2008.

Jin, X. and Gruber, N.: Offsetting the radiative benefit of ocean iron fertilization by enhancing $\mathrm{N}_{2} \mathrm{O}$ emissions, Geophys. Res. Lett., 30, 2249, https://doi.org/10.1029/2003GL018458, 2003.

Jin, X., Gruber, N., Frenzel, H., Doney, S. C., and McWilliams, J. C.: The impact on atmospheric $\mathrm{CO}_{2}$ of iron fertilization induced changes in the ocean's biological pump, Biogeosciences, 5, 385406, https://doi.org/10.5194/bg-5-385-2008, 2008.

Johnson, K. S. and Karl, D. M.: Is Ocean Fertilization Credible and Creditable?, Science, 296, 467-468, https://doi.org/10.1126/science.296.5567.467b, 2002.

Joos, F., Sarmiento, J. L., and Siegenthaler, U.: Estimates of the effect of Southern Ocean iron fertilization on atmospheric $\mathrm{CO}_{2}$ concentrations, Nature, 349, 772-775, https://doi.org/10.1038/349772a0, 1991.

Kahler, P. and Bauerfeind, E.: Organic particles in a shallow sediment trap, Substantial loss to the dissolved phase, Limnol. Oceanogr., 46, 719-723, https://doi.org/10.4319/lo.2001.46.3.0719, 2001.

Karl, D. M. and Knauer, G. A.: Swimmers, a recapitulation of the problem and a potential solution, Oceanography, 2, 32-35, https://doi.org/10.5670/oceanog.1989.28, 1989.

Keller, D. P., Feng, E. Y., and Oschlies, A.: Potential climate engineering effectiveness and side effects during a high 
carbon dioxide-emission scenario, Nat. Commun., 5, 3304, https://doi.org/10.1038/ncomms4304, 2014.

Knauer, G. A., Karl, D. M., Martin, J. H., and Hunter, C. N.: In situ effects of selected preservatives on total carbon, nitrogen and metals collected in sediment traps, J. Mar. Res., 42, 445-462, https://doi.org/10.1357/002224084788502710, 1984.

Kolber, Z. S., Barber, R. T., Coale, K. H., Fitzwateri, S. E., Greene, R. M., Johnson, K. S., Lindley, S., and Falkowski, P. G.: Iron limitation of phytoplankton photosynthesis in the equatorial Pacific Ocean, Nature, 371, 145-149, https://doi.org/10.1038/371145a0, 1994.

Kudo, I., Noiri, Y., Cochlan, W. P., Suzuki, K., Aramaki, T., Ono, T., and Nojiri, Y.: Primary productivity, bacterial productivity and nitrogen uptake in response to iron enrichment during the SEEDS II, Deep-Sea Res. Pt. II, 56, 2755-2766, https://doi.org/10.1016/j.dsr2.2009.06.003, 2009.

Kurz, K. D. and Maier-Reimer, E.: Iron fertilization of the austral ocean - the Hamburg model assessment, Global Biogeochem. Cy., 7, 229-244, https://doi.org/10.1029/92GB02910, 1993.

Lampitt, R. S., Achterberg, E. P., Anderson, T. R., Hughes, J. A., Iglesias-Rodriguez, M. D., Kelly-Gerreyn, B. A., Lucas, M., Popova, E. E., Sanders, R., Shepherd, J. G., SmytheWright, D., and Yool, A.: Ocean fertilization: a potential means of geoengineering?, Phil. Trans. R. Soc. A, 366, 3919-3945, https://doi.org/10.1098/rsta.2008.0139, 2008.

Landry, M. R., Ondrusek, M. E., Tanner, S. J., Brown, S. L., Constantinou, J., Bidigare, R. R., Coale, K. H., and Fitzwater, S.: Biological response to iron fertilization in the eastern equatorial Pacific (IronEx II). I. Microplankton community abundances and biomass, Mar. Ecol. Prog. Ser., 201, 27-42, https://doi.org/10.3354/meps201027, 2000.

Latasa, M., Henjes, J., Scharek, R., Assmy, P., Rottgers, R., and Smetacek, V.: Progressive decoupling between phytoplankton growth and microzooplankton grazing during an iron-induced phytoplankton bloom in the Southern Ocean (EIFEX), Mar. Ecol. Prog. Ser., 513, 39-50, https://doi.org/10.3354/meps10937, 2014.

Law, C. S.: Predicting and monitoring the effects of large-scale ocean iron fertilization on marine trace gas emissions, Mar. Ecol. Prog. Ser., 364, 283-288, https://doi.org/10.3354/meps07549, 2008.

Law, C. S. and Ling, R. D.: Nitrous oxide flux and response to increased iron availability in the Antarctic Circumpolar Current, Deep-Sea Res. Pt. II, 48, 2509-2527, https://doi.org/10.1016/S0967-0645(01)00006-6, 2001.

Law, C. S., Watson, A. J., Liddicoat, M. I., and Stanton, T.: Sulphur hexafluoride as a tracer of biogeochemical and physical processes in an open-ocean iron fertilisation experiment, DeepSea Res. Pt. II, 45, 977-994, https://doi.org/10.1016/S09670645(98)00022-8, 1998

Law, C. S., Abraham, E. R., Watson, A. J., and Liddicoat, M. I.: Vertical eddy diffusion and nutrient supply to the surface mixed layer of the Antarctic Circumpolar Current, J. Geophys. Res., 108, 3272, https://doi.org/10.1029/2002JC001604, 2003.

Law, C. S., Crawford, W. R., Smith, M. J., Boyd, P. W., Wong, C. S., Nojiri, Y., Robert, M., Abraham, E. R., Johnson, W. K., Forsland, V., and Arychuk, M.: Patch evolution and the biogeochemical impact of entrainment during an iron fertilisation experiment in the sub-Arctic Pacific, Deep-Sea Res. Pt. II, 53, 2012-2033, https://doi.org/10.1016/j.dsr2.2006.05.028, 2006.

Law, C. S., Smith, M. J., Stevens, C. L., Abraham, E. R., Ellwood, M. J., Hill, P., Nodder, S., Peloquin, J., Pickmere, S., Safi, K., and Walkington, C. M.: Did dilution limit the phytoplankton response to iron addition in HNLCLSi sub-Antarctic waters during the SAGE experiment?, Deep-Sea Res. Pt. II, 58, 786-799, https://doi.org/10.1016/j.dsr2.2010.10.018, 2011.

Lawrence, M. G.: Side Effects of Oceanic Iron Fertilization, Science, 297, 1993 https://doi.org/10.1126/science.297.5589.1993b, 2002.

Lenton, T. M. and Vaughan, N. E.: The radiative forcing potential of different climate geoengineering options, Atmos. Chem. Phys., 9, 5539-5561, https://doi.org/10.5194/acp-9-5539-2009, 2009.

Leung, D. Y. C., Caramanna, G., and Maroto-Valer, M. M.: An overview of current status of carbon dioxide capture and storage technologies, Renew. Sust. Energ. Rev., 39, 426-443, https://doi.org/10.1016/j.rser.2014.07.093, 2014.

Levasseur, M., Scarratt, M. G., Michaud, S., Merzouk, A., Wong, C. S., Arychuk, M., Richardson, W., Rivkin, R. B., Hale, M., Wong, E., Marchetti, A., and Kiyosawa, H.: DMSP and DMS dynamics during a mesoscale iron fertilization experiment in the Northeast Pacific - Part I: Temporal and vertical distributions, Deep-Sea Res. Pt. II, 53, 2353-2369, https://doi.org/10.1016/j.dsr2.2006.05.023, 2006.

Liss, P., Chuck, A., Bakker, D., and Turner, S.: Ocean fertilization with iron: effects on climate and air quality, Tellus B, 57, 269271, https://doi.org/10.1111/j.1600-0889.2005.00141.x, 2005.

London Convention: Convention on the Prevention of Marine Pollution by Dumping of Wastes and Other Matter 1972, 1972.

London Protocol: 1996 Protocol to the Convention on the Prevention of Marine Pollution by Dumping of Wastes and Other Matter, 1972, 1996.

Marchetti, A., Sherry, N. D., Juneau, P., Strzepek, R. F., and Harrison, P. J.: Phytoplankton processes during a mesoscale iron enrichment in the NE subarctic Pacific: Part III - Primary productivity, Deep-Sea Res. Pt. II, 53, 2131-2151, https://doi.org/10.1016/j.dsr2.2006.05.032, 2006a.

Marchetti, A., Sherry, N. D., Kiyosawa, H., Tsuda, A., and Harrison, P. J.: Phytoplankton processes during a mesoscale iron enrichment in the NE subarctic Pacific: Part I Biomass and assemblage, Deep-Sea Res. Pt. II, 53, 2095-2113, https://doi.org/10.1016/j.dsr2.2006.05.038, 2006b.

Marchetti, A., Lundholm, N., Kotaki, Y., Hubbard, K., Harrison, P. J., and Virginia Armbrust, E.: Identification and assessment of domoic acid production in oceanic Pseudo-nitzschia (Bacillariophyceae) from iron-limited waters in the Northeast Subarctic Pacific, J. Phycol., 650-661, https://doi.org/10.1111/j.15298817.2008.00526.x, 2008.

Marshall, J. and Speer, K.: Closure of the meridional overturning circulation through Southern Ocean upwelling, Nat. Geosci., 5, 171-180, https://doi.org/10.1038/ngeo1391, 2012.

Martin, J. H. and Fitzwater, S. E.: Iron deficiency limits phytoplankton growth in the north-east Pacific subarctic, Nature, 331, 341343, https://doi.org/10.1038/331341a0, 1988.

Martin, J. H.: Glacial-interglacial $\mathrm{CO}_{2}$ change: The Iron Hypothesis, Paleoceanography, 5, 1-13, https://doi.org/10.1029/PA005i001p00001, 1990. 
Martin, J. H. and Chisholm, P.: Design for a mesoscale iron enrichment experiment. Woods Hole Oceanographic Institution, U.S. JGOFS Planning Report, 15, 1992.

Martin, J. H., Coale, K. H., Johnson, K. S., Fitzwater, S. E., Gordon, R. M., Tanner, S. J., Hunter, C. N., Elrod, V. A., Nowicki, J. L., Coley, T. L., Barber, R. T., Lindley, S., Watson, A. J., Van Scoy, K., Law, C. S., Liddicoat, M. I., Ling, R., Stanton, T., Stockel, J., Collins, C., Anderson, A., Bidigare, R., Ondrusek, M., Latasa, M., Millero, F. J., Lee, K., Yao, W., Zhang, J. Z., Friederich, G., Sakamoto, C., Chavez, F., Buck, K., Kolber, Z., Greene, R., Falkowski, P., Chisholm, S. W., Hoge, F., Swift, R., Yungel, J., Turner, S., Nightingale, P., Hatton, A., Liss, P., and Tindale, N. W.: Testing the iron hypothesis in ecosystems of the equatorial Pacific Ocean, Nature, 371, 123-129, https://doi.org/10.1038/371123a0, 1994.

Martin, P., van der Loeff, M. R., Cassar, N., Vandromme, P., d'Ovidio, F., Stemmann, L., Rengarajan, R., Soares, M., Gonzalez, H. E., Ebersbach, F., Lampitt, R. S., Sanders, R., Barnett, B. A., Smetacek, V., and Naqvi, S. W. A.: Iron fertilization enhanced net community production but not downward particle flux during the Southern Ocean iron fertilization experiment LOHAFEX, Global Biogeochem. Cy., 27, 871-881, https://doi.org/10.1002/gbc.20077, 2013.

Matthews, B.: Climate engineering: a critical review of proposals, their scientific and political context, and possible impacts, Compiled for scientists for global responsibility, available at: http://www.chooseclimate.org/cleng/part1b.html (last access: 6 September 2018), 1996.

McElroy, M. B.: Marine biological controls on atmospheric $\mathrm{CO}_{2}$ and climate, Nature, 302, 328-329, https://doi.org/10.1038/302328a0, 1983.

Meinshausen, M., Smith, S. J., Calvin, K., Daniel, J. S., Kainuma, M. L. T., Lamarque, J.-F., Matsumoto, K., Montzka, S. A., Raper, S. C. B., Riahi, K., Thomson, A., Velders, G. J. M., and van Vuuren, D. P. P.: The RCP greenhouse gas concentrations and their extensions from 1765 to 2300, Clim. Change, 109, 213, https://doi.org/10.1007/s10584-011-0156-z, 2011.

Mengelt, C., Abbott, M. R., Barth, J. A., Letelier, R. M., Measures, C. I., and Vink, S.: Phytoplankton pigment distribution in relation to silicic acid, iron and the physical structure across the Antarctic Polar Front, $170^{\circ} \mathrm{W}$, during austral summer, DeepSea Res. Pt. II, 48, 4081-4100, https://doi.org/10.1016/S09670645(01)00081-9, 2001

Mills, M. M., Ridame, C., Davey, M., La Roche, J., and Geider, R. J.: Iron and phosphorus co-limit nitrogen fixation in the eastern tropical North Atlantic, Nature, 429, 292, https://doi.org/10.1038/nature02550, 2004.

Ming, T., de Richter, R., Liu, W., and Caillol, S.: Fighting global warming by climate engineering: Is the Earth radiation management and the solar radiation management any option for fighting climate change?, Renew. Sust. Energ. Rev., 31, 792-834, https://doi.org/10.1016/j.rser.2013.12.032, 2014.

Mitchell, B. G., Brody, E. A., Holm-Hansen, O., McClain, C., and Bishop, J.: Light limitation of phytoplankton biomass and macronutrient utilization in the Southern Ocean, Limnol. Oceanogr., 36, 1662-1677, https://doi.org/10.4319/lo.1991.36.8.1662, 1991.

Moore, J. K. and Abbott, M. R.: Surface chlorophyll concentrations in relation to the Antarctic Polar Front: seasonal and spatial patterns from satellite observations, J. Marine Syst., 37, 69-86, https://doi.org/10.1016/S0924-7963(02)00196-3, 2002.

Morel, F. M. M. and Price, N. M.: The Biogeochemical Cycles of Trace Metals in the Oceans, Science, 300, 944-947, https://doi.org/10.1126/science.1083545, 2003.

Morris, P. J. and Charette, M. A.: A synthesis of upper ocean carbon and dissolved iron budgets for Southern Ocean natural iron fertilisation studies, Deep-Sea Res. Pt. II, 90, 147-157, https://doi.org/10.1016/j.dsr2.2013.02.001, 2013.

Morrow, R. and Le Traon, P.-Y.: Recent advances in observing mesoscale ocean dynamics with satellite altimetry, Adv. Space Res., 50, 1062-1076, https://doi.org/10.1016/j.asr.2011.09.033, 2012.

Nagao, I., Hashimoto, S., Suzuki, K., Toda, S., Narita, Y., Tsuda, A., Saito, H., Kudo, I., Kato, S., Kajii, Y., and Uematsu, M.: Responses of DMS in the seawater and atmosphere to iron enrichment in the subarctic western North Pacific (SEEDS-II), Deep-Sea Res. Pt. II, 56, 2899-2917, https://doi.org/10.1016/j.dsr2.2009.07.001, 2009.

Neftel, A., Oeschger, H., Schwander, J., Stauffer, B., and Zumbrunn, R.: Ice core sample measurements give atmospheric $\mathrm{CO}_{2}$ content during the past 40,000 yr, Nature, 295, 220-223, https://doi.org/10.1038/295220a0, 1982.

Nelson, D. M., Brzezinski, M. A., Sigmon, D. E., and Franck, V. M.: A seasonal progression of Si limitation in the Pacific sector of the Southern Ocean, Deep-Sea Res. Pt. II, 48, 3973-3995, https://doi.org/10.1016/S0967-0645(01)00076-5, 2001.

Nevison, C., Butler, J. H., and Elkins, J. W.: Global distribution of $\mathrm{N}_{2} \mathrm{O}$ and the $\Delta \mathrm{N}_{2} \mathrm{O}$-AOU yield in the subsurface ocean, Global Biogeochem. Cy., 17, 1119, https://doi.org/10.1029/2003GB002068, 2003.

Nishioka, J., Takeda, S., Baar, H. J. W. D., Croot, P. L., Boye, M., Laan, P., and Timmermans, K. R.: Changes in the concentration of iron in different size fractions during an iron enrichment experiment in the open Southern Ocean, Mar. Chem., 95, 51-63, https://doi.org/10.1016/j.marchem.2004.06.040, 2005.

Nodder, S. D. and Waite, A. M.: Is Southern Ocean organic carbon and biogenic silica export enhanced by ironstimulated increases in biological production? Sediment trap results from SOIREE, Deep-Sea Res. Pt. II, 48, 2681-2701, https://doi.org/10.1016/S0967-0645(01)00014-5, 2001.

Nodder, S. D., Charette, M. A., Waite, A. M., Trull, T. W., Boyd, P. W., Zeldis, J., and Buesseler, K. O.: Particle transformations and export flux during an in situ iron-stimulated algal bloom in the Southern Ocean, Geophys. Res. Lett., 28, 2409-2412, https://doi.org/10.1029/2001GL013008, 2001.

Noiri, Y., Kudo, I., Kiyosawa, H., Nishioka, J., and Tsuda, A.: Influence of iron and temperature on growth, nutrient utilization ratios and phytoplankton species composition in the western subarctic Pacific Ocean during the SEEDS experiment, Prog. Oceanogr., 64, 149-166, https://doi.org/10.1016/j.pocean.2005.02.006, 2005.

Oliver, J. L., Barber, R. T., Smith, W. O., and Ducklow, H. W.: The heterotrophic bacterial response during the Southern Ocean Iron Experiment (SOFeX), Limnol. Oceanogr., 49, 2129-2140, https://doi.org/10.4319/lo.2004.49.6.2129, 2004.

Oschlies, A., Koeve, W., Rickels, W., and Rehdanz, K.: Side effects and accounting aspects of hypothetical large-scale South- 
ern Ocean iron fertilization, Biogeosciences, 7, 4017-4035, https://doi.org/10.5194/bg-7-4017-2010, 2010.

Park, K.-T., Lee, K., Shin, K., Yang, E. J., Hyun, B., Kim, J.-M., Noh, J. H., Kim, M., Kong, B., Choi, D. H., Choi, S.-J., Jang, P.-G., and Jeong, H. J.: Direct linkage between dimethyl sulfide production and microzooplankton grazing, resulting from prey composition change under high partial pressure of carbon dioxide conditions, Environ. Sci. Technol., 48, 4750-4756, https://doi.org/10.1021/es403351h, 2014.

Peloquin, J., Hall, J., Safi, K., Ellwood, M., Law, C. S., Thompson, K., Kuparinen, J., Harvey, M., and Pickmere, S.: Control of the phytoplankton response during the SAGE experiment: A synthesis, Deep-Sea Res. Pt. II, 58, 824-838, https://doi.org/10.1016/j.dsr2.2010.10.019, 2011a.

Peloquin, J., Hall, J., Safi, K., Smith, W. O., Wright, S., and van den Enden, R.: The response of phytoplankton to iron enrichment in Sub-Antarctic HNLCLSi waters: Results from the SAGE experiment, Deep-Sea Res. Pt. II, 58, 808-823, https://doi.org/10.1016/j.dsr2.2010.10.021, 2011 b.

Peng, T.-H. and Broecker, W. S.: Factors limiting the reduction of atmospheric $\mathrm{CO}_{2}$ by iron fertilization, Limnol. Oceanogr., 36, 1919-1927, https://doi.org/10.4319/lo.1991.36.8.1919, 1991.

Petit, J. R., Jouzel, J., Raynaud, D., Barkov, N. I., Barnola, J. M., Basile, I., Bender, M., Chappellaz, J., Davis, M., Delaygue, G., Delmotte, M., Kotlyakov, V. M., Legrand, M., Lipenkov, V. Y., Lorius, C., Pepin, L., Ritz, C., Saltzman, E., and Stievenard, M.: Climate and atmospheric history of the past 420,000 years from the Vostok ice core, Antarctica, Nature, 399, 429-436, https://doi.org/10.1038/20859, 1999.

Pollard, R. T., Salter, I., Sanders, R. J., Lucas, M. I., Moore, C. M., Mills, R. A., Statham, P. J., Allen, J. T., Baker, A. R., Bakker, D. C. E., Charette, M. A., Fielding, S., Fones, G. R., French, M., Hickman, A. E., Holland, R. J., Hughes, J. A., Jickells, T. D., Lampitt, R. S., Morris, P. J., Nedelec, F. H., Nielsdottir, M., Planquette, H., Popova, E. E., Poulton, A. J., Read, J. F., Seeyave, S., Smith, T., Stinchcombe, M., Taylor, S., Thomalla, S., Venables, H. J., Williamson, R., and Zubkov, M. V.: Southern Ocean deepwater carbon export enhanced by natural iron fertilization, Nature, 457, 577-580, https://doi.org/10.1038/nature07716, 2009.

Purser, A., Thomsen, L., Barnes, C., Best, M., Chapman, R., Hofbauer, M., Menzel, M., and Wagner, H.: Temporal and spatial benthic data collection via an internet operated Deep Sea Crawler, Methods in Oceanography, 5, 1-18, https://doi.org/10.1016/j.mio.2013.07.001, 2013.

Queguiner, B., Treguer, P., Peeken, I., and Scharek, R.: Biogeochemical dynamics and the silicon cycle in the Atlantic sector of the Southern Ocean during austral spring 1992, Deep-Sea Res. Pt. II, 44, 69-89, https://doi.org/10.1016/S0967-0645(96)000665, 1997.

Rees, A. P., Nightingale, P. D., Owens, N. J. P., and Team, P. F.: $\mathrm{FeeP}-\mathrm{An}$ in situ $\mathrm{PO}_{4}^{3-}$ and $\mathrm{Fe}^{2+}$ addition experiment to waters of the sub-tropical north-east Atlantic, Geophys. Res. Abstr., 9, 01440, 2007.

Rembauville, M., Blain, S., Armand, L., Quéguiner, B., and Salter, I.: Export fluxes in a naturally iron-fertilized area of the Southern Ocean - Part 2: Importance of diatom resting spores and faecal pellets for export, Biogeosciences, 12, 3171-3195, https://doi.org/10.5194/bg-12-3171-2015, 2015.
Rembauville, M., Manno, C., Tarling, G. A., Blain, S., and Salter, I.: Strong contribution of diatom resting spores to deepsea carbon transfer in naturally iron-fertilized waters downstream of South Georgia, Deep-Sea Res. Pt. I, 115, 22-35, https://doi.org/10.1016/j.dsr.2016.05.002, 2016.

Resolution LC-LP.1: Regulation of Ocean Fertilization, LC 30/16, Annex 6, 2008.

Resolution LC-LP.2: Assessment Framework for Scientific Research Involving Ocean Fertilization, LC 32/15, Annex 6, 2010.

Resolution LP.4 (8): Amendment to the London Protocol to Regulate the Placement of Matter for Ocean Fertilization and Other Marine Geoengineering Activities, LP.8, LC 35/15, Annex 4, Annex 5, 2013.

Rogelj, J., Michiel, S., Malte, M., Reto, K., Joseph, A., Keywan, R., and William, H.: Zero emission targets as long-term global goals for climate protection, Environ. Res. Lett., 10, 105007, https://doi.org/10.1088/1748-9326/10/10/105007, 2015.

Rollwagen Bollens, G. C. and Landry, M. R.: Biological response to iron fertilization in the eastern equatorial Pacific (IronEx II). II. Mesozooplankton abundance, biomass, depth distribution and grazing, Mar. Ecol. Pro. Ser., 201, 43-56, https://doi.org/10.3354/meps201043, 2000.

Salter, I., Lampitt, R. S., Sanders, R., Poulton, A., Kemp, A. E. S., Boorman, B., Saw, K., and Pearce, R.: Estimating carbon, silica and diatom export from a naturally fertilised phytoplankton bloom in the Southern Ocean using PELAGRA: A novel drifting sediment trap, Deep-Sea Res. Pt. II, 54, 2233-2259, https://doi.org/10.1016/j.dsr2.2007.06.008, 2007.

Sarmiento, J. L. and Gruber, N.: Ocean Biogeochemical Dynamics, Princeton University Press, Princeton, New Jersey, 2006.

Sarmiento, J. L. and Orr, J. C.: Three-dimensional simulations of the impact of Southern Ocean nutrient depletion on atmospheric $\mathrm{CO}_{2}$ and ocean chemistry, Limnol. Oceanogr., 36, 1928-1950, https://doi.org/10.4319/lo.1991.36.8.1928, 1991.

Sarmiento, J. L., Slater, R. D., Dunne, J., Gnanadesikan, A., and Hiscock, M. R.: Efficiency of small scale carbon mitigation by patch iron fertilization, Biogeosciences, 7, 3593-3624, https://doi.org/10.5194/bg-7-3593-2010, 2010.

Sato, M., Takeda, S., and Furuya, K.: Responses of pico- and nanophytoplankton to artificial iron infusions observed during the second iron enrichment experiment in the western subarctic Pacific (SEEDS II), Deep-Sea Res. Pt. II, 56, 2745-2754, https://doi.org/10.1016/j.dsr2.2009.06.002, 2009.

Schiermeier, Q.: The oresmen, Nature, 421, 109-110, https://doi.org/10.1038/421109a, 2003.

Schlitzer, R.: Ocean Data View, available at: http://odv.awi.de (last access: 6 September 2018), 2017.

Schnetzer, A., Miller, P. E., Schaffner, R. A., Stauffer, B. A., Jones, B. H., Weisberg, S. B., DiGiacomo, P. M., Berelson, W. M., and Caron, D. A.: Blooms of Pseudo-nitzschia and domoic acid in the San Pedro Channel and Los Angeles harbor areas of the Southern California Bight, 2003-2004, Harmful Algae, 6, 372-387, https://doi.org/10.1016/j.hal.2006.11.004, 2007.

Scholin, C. A., Gulland, F., Doucette, G. J., Benson, S., Busman, M., Chavez, F. P., Cordaro, J., DeLong, R., De Vogelaere, A. Harvey, J., Haulena, M., Lefebvre, K., Lipscomb, T., Loscutoff, S., Lowenstine, L. J., Marin Iii, R., Miller, P. E., McLellan, W. A., Moeller, P. D. R., Powell, C. L., Rowles, T., Silvagni, P., Silver, M., Spraker, T., Trainer, V., and Van Dolah, F. M.: Mortality 
of sea lions along the central California coast linked to a toxic diatom bloom, Nature, 403, 80, https://doi.org/10.1038/47481, 2000.

Schultes, S., Verity, P. G., and Bathmann, U.: Copepod grazing during an iron-induced diatom bloom in the Antarctic Circumpolar Current (EisenEx): I. Feeding patterns and grazing impact on prey populations, J. Exp. Mar. Bio. Ecol., 338, 16-34, https://doi.org/10.1016/j.jembe.2006.06.028, 2006.

Sigman, D. M. and Boyle, E. A.: Glacial/interglacial variations in atmospheric carbon dioxide, Nature, 407, 859-869, https://doi.org/10.1038/35038000, 2000.

Silver, M. W., Bargu, S., Coale, S. L., Benitez-Nelson, C. R., Garcia, A. C., Roberts, K. J., Sekula-Wood, E., Bruland, K. W., and Coale, K. H.: Toxic diatoms and domoic acid in natural and iron enriched waters of the oceanic Pacific, P. Natl. Acad. Sci. USA, 107, 20762-20767, https://doi.org/10.1073/pnas.1006968107, 2010.

Smetacek, V.: EisenEx: International Team Conducts Iron Experiment In Southern Ocean, U.S. JGOFS News, 11, 11-14, 2001.

Smetacek, V.: Ocean iron fertilization experiments: The dawn of a new era in applied ocean sciences?, KOPRI, Korea, 2015.

Smetacek, V. and Naqvi, S. W. A.: The next generation of iron fertilization experiments in the Southern Ocean, Philos. T. Roy. Soc. A, 366, 3947-3967, https://doi.org/10.1098/rsta.2008.0144, 2008.

Smetacek, V.: Seeing is believing: Diatoms and the Ocean Carbon Cycle revisited, Protist, https://doi.org/10.1016/j.protis.2018.08.004, in press, 2018.

Smetacek, V. and Naqvi, S. W. A.: The expedition of the research vessel "Polarstern" to the Antarctic in 2009 (ANT-XXV/3 - LOHAFEX), Berichte zur Polar- und Meeresforschung (Reports on Polar and Marine Research), Alfred Wegener Institute for Polar and Marine Research, Bremerhaven, 613, 2010.

Smetacek, V., Klaas, C., Menden-Deuer, S., and Rynearson, T. A.: Mesoscale distribution of dominant diatom species relative to the hydrographical field along the Antarctic Polar Front, DeepSea Res. Pt. II, 49, 3835-3848, https://doi.org/10.1016/S09670645(02)00113-3, 2002.

Smetacek, V., Bathmann, U., and Helmke, E.: The expeditions Antarktis XXI/3-4-5 of the Research Vessel "Polarstern" in 2004, Reports on Polar and Marine Research, 500, 1-299, 2005.

Smetacek, V., Klaas, C., Strass, V. H., Assmy, P., Montresor, M., Cisewski, B., Savoye, N., Webb, A., d/'Ovidio, F., Arrieta, J. M., Bathmann, U., Bellerby, R., Berg, G. M., Croot, P., Gonzalez, S., Henjes, J., Herndl, G. J., Hoffmann, L. J., Leach, H., Losch, M., Mills, M. M., Neill, C., Peeken, I., Rottgers, R., Sachs, O., Sauter, E., Schmidt, M. M., Schwarz, J., Terbruggen, A., and Wolf-Gladrow, D.: Deep carbon export from a Southern Ocean iron-fertilized diatom bloom, Nature, 487, 313-319, https://doi.org/10.1038/nature11229, 2012.

Solomon, S., Garcia, R. R., and Ravishankara, A. R.: On the role of iodine in ozone depletion, J. Geophys. Res., 99, 20491-20499, https://doi.org/10.1029/94JD02028, 1994.

Spolaor, A., Vallelonga, P., Cozzi, G., Gabrieli, J., Varin, C., Kehrwald, N., Zennaro, P., Boutron, C., and Barbante, C.: Iron speciation in aerosol dust influences iron bioavailability over glacial-interglacial timescales, Geophys. Res. Lett., 40, 16181623, https://doi.org/10.1002/grl.50296, 2013.
Stanton, T. P., Law, C. S., and Watson, A. J.: Physical evolution of the IronEx-I open ocean tracer patch, Deep-Sea Res. Pt. II, 45, 947-975, https://doi.org/10.1016/S0967-0645(98)000186, 1998.

Steinberg, P. A., Millero, F. J., and Zhu, X.: Carbonate system response to iron enrichment, Mar. Chem., 62, 31-43, https://doi.org/10.1016/S0304-4203(98)00031-0, 1998.

Strong, A. L., Cullen, J. J., and Chisholm, S. W.: Ocean fertilization: Science, policy, and commerce, Oceanography, 22, 236261, https://doi.org/10.5670/oceanog.2009.83, 2009.

Suess, E.: Particulate organic carbon flux in the oceans - Surface productivity and oxygen utilization, Nature, 288, 260-263, https://doi.org/10.1038/288260a0, 1980.

Sunda, W. G., Swift, D. G., and Hunstman, S.: Low requirement for growth in oceanic phytoplankton, Nature, 351, 55-57, https://doi.org/10.1038/351055a0, 1991.

Suzuki, K., Hinuma, A., Saito, H., Kiyosawa, H., Liu, H., Saino, T., and Tsuda, A.: Responses of phytoplankton and heterotrophic bacteria in the northwest subarctic Pacific to in situ iron fertilization as estimated by HPLC pigment analysis and flow cytometry, Prog. Oceanogr., 64, 167-187, https://doi.org/10.1016/j.pocean.2005.02.007, 2005.

Suzuki, K., Saito, H., Isada, T., Hattori-Saito, A., Kiyosawa, H., Nishioka, J., McKay, R. M. L., Kuwata, A., and Tsuda, A.: Community structure and photosynthetic physiology of phytoplankton in the northwest subarctic Pacific during an in situ iron fertilization experiment (SEEDS-II), Deep-Sea Res. Pt. II, 56, 2733 2744, https://doi.org/10.1016/j.dsr2.2009.06.001, 2009.

Takeda, S. and Tsuda, A.: An in situ iron-enrichment experiment in the western subarctic Pacific (SEEDS): Introduction and summary, Prog. Oceanogr., 64, 95-109, https://doi.org/10.1016/j.pocean.2005.02.004, 2005.

Thiele, S., Fuchs, B. M., Ramaiah, N., and Amann, R.: Microbial Community Response during the Iron Fertilization Experiment LOHAFEX, Appl. Environ. Microbiol., 78, 8803-8812, https://doi.org/10.1128/AEM.01814-12, 2012.

Treguer, P., Nelson, D. M., Van Bennekom, A. J., DeMaster, D. J., Leynaert, A., and Queguiner, B.: The Silica Balance in the World Ocean: A Reestimate, Science, 268, 375-379, https://doi.org/10.1126/science.268.5209.375, 1995.

Trick, C. G., Bill, B. D., Cochlan, W. P., Wells, M. L., Trainer, V. L., and Pickell, L. D.: Iron enrichment stimulates toxic diatom production in high-nitrate, lowchlorophyll areas, P. Natl. Acad. Sci. USA, 107, 5887-5892, https://doi.org/10.1073/pnas.0910579107, 2010.

Trull, T., and Armand, L. K.: Insights into Southern Ocean carbon export from the $\delta^{13} \mathrm{C}$ of particles and dissolved inorganic carbon during the SOIREE iron release experiment, DeepSea Res. Pt. II, 48, 2655-2680, https://doi.org/10.1016/S09670645(01)00013-3, 2001.

Tsuda, A., Takeda, S., Saito, H., Nishioka, J., Nojiri, Y., Kudo, I., Kiyosawa, H., Shiomoto, A., Imai, K., Ono, T., Shimamoto, A., Tsumune, D., Yoshimura, T., Aono, T., Hinuma, A., Kinugasa, M., Suzuki, K., Sohrin, Y., Noiri, Y., Tani, H., Deguchi, Y., Tsurushima, N., Ogawa, H., Fukami, K., Kuma, K., and Saino, T.: A Mesoscale Iron Enrichment in the Western Subarctic Pacific Induces a Large Centric Diatom Bloom, Science, 300, 958-961, https://doi.org/10.1126/science.1082000, 2003. 
Tsuda, A., Kiyosawa, H., Kuwata, A., Mochizuki, M., Shiga, N., Saito, H., Chiba, S., Imai, K., Nishioka, J., and Ono, T.: Responses of diatoms to iron-enrichment (SEEDS) in the western subarctic Pacific, temporal and spatial comparisons, Prog. Oceanogr., 64, 189-205, https://doi.org/10.1016/j.pocean.2005.02.008, 2005.

Tsuda, A., Takeda, S., Saito, H., Nishioka, J., Kudo, I., Nojiri, Y., Suzuki, K., Uematsu, M., Wells, M. L., Tsumune, D., Yoshimura, T., Aono, T., Aramaki, T., Cochlan, W. P., Hayakawa, M., Imai, K., Isada, T., Iwamoto, Y., Johnson, W. K., Kameyama, S., Kato, S., Kiyosawa, H., Kondo, Y., Levasseur, M., Machida, R. J., Nagao, I., Nakagawa, F., Nakanishi, T., Nakatsuka, S., Narita, A., Noiri, Y., Obata, H., Ogawa, H., Oguma, K., Ono, T., Sakuragi, T., Sasakawa, M., Sato, M., Shimamoto, A., Takata, H., Trick, C. G., Watanabe, Y. W., Wong, C. S., and Yoshie, N.: Evidence for the grazing hypothesis: Grazing reduces phytoplankton responses of the HNLC ecosystem to iron enrichment in the western subarctic pacific (SEEDS II), J. Oceanogr., 63, 983-994, https://doi.org/10.1007/s10872-007-0082-x, 2007.

Tsuda, A., Saito, H., Machida, R. J., and Shimode, S., Meso- and microzooplankton responses to an in situ iron fertilization experiment (SEEDS II) in the northwest subarctic Pacific, Deep-Sea Res. Pt. II, 56, 2767-2778, https://doi.org/10.1016/j.dsr2.2009.06.004, 2009.

Tsumune, D., Nishioka, J., Shimamoto, A., Takeda, S., and Tsuda, A.: Physical behavior of the SEEDS iron-fertilized patch by sulphur hexafluoride tracer release, Prog. Oceanogr., 64, 111-127, https://doi.org/10.1016/j.pocean.2005.02.018, 2005.

Tsumune, D., Nishioka, J., Shimamoto, A., Watanabe, Y. W., Aramaki, T., Nojiri, Y., Takeda, S., Tsuda, A., and Tsubono, T.: Physical behaviors of the iron-fertilized patch in SEEDS II, Deep-Sea Res. Pt. II, 56, 2948-2957, https://doi.org/10.1016/j.dsr2.2009.07.004, 2009.

Turner, S. M., Nightingale, P. D., Spokes, L. J., Liddicoat, M. I., and Liss, P. S.: Increased dimethyl sulphide concentrations in sea water from in situ iron enrichment, Nature, 383, 513-517, https://doi.org/10.1038/383513a0, 1996.

Turner, S. M., Harvey, M. J., Law, C. S., Nightingale, P. D., and Liss, P. S.: Iron-induced changes in oceanic sulfur biogeochemistry, Geophys. Res. Lett., 31, L14307, https://doi.org/10.1029/2004GL020296, 2004.

Twining, B. S., Baines, S. B., and Fisher, N. S.: Element stoichiometries of individual plankton cells collected during the Southern Ocean Iron Experiment (SOFeX), Limnol. Oceanogr., 49, 21152128, https://doi.org/10.4319/lo.2004.49.6.2115, 2004.

Valdes, J. R. and Buesseler, K. O.: The neutrally buoyant sediment trap (NBST), a new tool for "Twilight Zone" particle exploration, Eos Trans. AGU Ocean Sci. Meeting Suppl., 87, Abstract OS26A-10, 2006.

Valdes, J. R. and Price, J. F.: A neutrally buoyant, upper ocean sediment trap, J. Atmos. Oceanogr. Technol., 17, 62-68, https://doi.org/10.1175/15200426(2000)017<0062:ANBUOS>2.0.CO;2, 2000.

Vaughan, N. E. and Lenton, T. M.: A review of climate geoengineering proposals, Clim. Change, 109, 745-790, https://doi.org/10.1007/s10584-011-0027-7, 2011.

Veth, C., Peeken, I., and Scharek, R.: Physical anatomy of fronts and surface waters in the ACC near $6^{\circ} \mathrm{W}$ meridian during austral spring 1992, Deep-Sea Res. Pt. II, 44, 23-49, https://doi.org/10.1016/S0967-0645(96)00062-8, 1997.

Volk, T. and Hoffert, M. I.: Ocean Carbon Pumps: Analysis of Relative Strengths and Efficiencies in Ocean-Driven Atmospheric $\mathrm{CO}_{2}$ Changes, in: The Carbon Cycle and Atmospheric $\mathrm{CO}_{2}$ : Natural Variations Archean to Present, Geophys. Monogr. Ser., 32, 99-110, 1985.

Waite, A. M. and Nodder, S. D.: The effect of in situ iron addition on the sinking rates and export flux of Southern Ocean diatoms, Deep-Sea Res. Pt. II, 48, 2635-2654, https://doi.org/10.1016/S0967-0645(01)00012-1, 2001.

Walter, S., Peeken, I., Lochte, K., Webb, A., and Bange, H. W.: Nitrous oxide measurements during EIFEX, the European Iron Fertilization Experiment in the subpolar South Atlantic Ocean, Geophys. Res. Lett., 32, L23613, https://doi.org/10.1029/2005GL024619, 2005.

Watson, A., Liss, P., and Duce, R.: Design of a small-scale in situ iron fertilization experiment, Limnol. Oceanogr., 36, 1960-1965, https://doi.org/10.4319/lo.1991.36.8.1960, 1991.

Wenzhofer, F., Lemburg, J., Hofbauer, M., Lehmenhecker, S., and Farber, P.: TRAMPER - An autonomous crawler for long-term benthic oxygen flux studies in remote deep sea ecosystems, OCEANS 2016 MTS/IEEE Monterey, 1-6, https://doi.org/10.1109/OCEANS.2016.7761217, 2016.

Westberry, T. K., Behrenfeld, M. J., Milligan, A. J., and Doney, S. C.: Retrospective satellite ocean color analysis of purposeful and natural ocean iron fertilization, Deep-Sea Res. Pt. I, 73, 1-16, https://doi.org/10.1016/j.dsr.2012.11.010, 2013.

Williamson, P., Wallace, D. W. R., Law, C. S., Boyd, P. W., Collos, Y., Croot, P., Denman, K., Riebesell, U., Takeda, S., and Vivian, C.: Ocean fertilization for geoengineering: A review of effectiveness, environmental impacts and emerging governance, Process Saf. Environ. Protect., 90, 475-488, https://doi.org/10.1016/j.psep.2012.10.007, 2012.

Wingenter, O. W., Haase, K. B., Strutton, P., Friederich, G., Meinardi, S., Blake, D. R., and Rowland, F. S.: Changing concentrations of $\mathrm{CO}, \mathrm{CH}_{4}, \mathrm{C}_{5} \mathrm{H}_{8}, \mathrm{CH}_{3} \mathrm{Br}, \mathrm{CH}_{3} \mathrm{I}$, and dimethyl sulfide during the Southern Ocean Iron Enrichment Experiments, P. Natl. Acad. Sci. USA, 101, 8537-8541, https://doi.org/10.1073/pnas.0402744101, 2004.

Wingenter, O. W., Elliot, S. M., and Blake, D. R.: New Directions: Enhancing the natural sulfur cycle to slow global warming, Atmos. Environ., 41, 7373-7375, https://doi.org/10.1016/j.atmosenv.2007.07.021, 2007.

Wong, C. S., Timothy, D. A., Law, C. S., Nojiri, Y., Xie, L., Wong, S.-K. E., and Page, J. S.: Carbon distribution and fluxes during the SERIES iron fertilization experiment with special reference to the fugacity of carbon dioxide $\left(f \mathrm{CO}_{2}\right)$, Deep-Sea Res. Pt II, 53, 2053-2074, https://doi.org/10.1016/j.dsr2.2006.05.036, 2006.

Xiu, P. and Chai, F.: Modeling the effects of size on patch dynamics of an inert tracer, Ocean Sci., 6, 413-421, https://doi.org/10.5194/os-6-413-2010, 2010.

Zahariev, K., Christian, J. R., and Denman, K. L.: Preindustrial, historical, and fertilization simulations using a global ocean carbon model with new parameterizations of iron limitation, calcification, and $\mathrm{N}_{2}$ fixation, Prog. Oceanogr., 77, 56-82, https://doi.org/10.1016/j.pocean.2008.01.007, 2008. 
Zeldis, J.: Mesozooplankton community composition, feeding, and export production during SOIREE, Deep-Sea Res. Pt. II, 48, 2615-2634, https://doi.org/10.1016/S0967-0645(01)00011$\mathrm{X}, 2001$.

Zhuang, G. and Duce, R. A.: The adsorption of dissolved iron on marine aerosol particles in surface waters of the open ocean, Deep-Sea Res. Pt. I, 40, 1413-1429, https://doi.org/10.1016/0967-0637(93)90120-R, 1993.
Zhuang, G., Yi, Z., Duce, R. A., and Brown, P. R.: Link between iron and sulphur cycles suggested by detection of $\mathrm{Fe}(\mathrm{II})$ in remote marine aerosols, Nature, 355, 537-539, https://doi.org/10.1038/355537a0, 1992. 